\title{
Optical manipulation of $\mathrm{F}$-actin with photoswitchable small molecules
}

Malgorzata Borowiak, ${ }^{1, \#}$ Florian Küllmer, ${ }^{2, \#}$ Florian Gegenfurtner, ${ }^{1}$ Sebastian Peil, ${ }^{2}$ Veselin Nasufovic, ${ }^{2}$ Stefan Zahler, ${ }^{1}$ Oliver Thorn-Seshold, ${ }^{1}$ Dirk Trauner, ${ }^{3} *$ and Hans-Dieter Arndt $^{2}{ }^{2} *$ - Supporting Information -

${ }^{1}$ Department of Pharmacy, Ludwig-Maximilians University, Butenandtstrasse 5-13, D-81377 München, Germany;

${ }^{2}$ Institute for Organic Chemistry and Macromolecular Chemistry, Friedrich-Schiller-University, Humboldtstrasse 10, D-07743 Jena, Germany;

${ }^{3}$ Department of Chemistry, New York University, 100 Washington Square East, New York, NY 10003, USA.

${ }^{\#}$ These authors contributed equally

*Contact: dirktrauner@nyu.edu or hd.arndt@uni-jena.de 


\section{TABLE OF CONTENTS}

Supplementary Figures............................................................................................................................ 3

Supplementary Video Material .......................................................................................................6 6

Materials and Methods - Chemistry ....................................................................................... 7

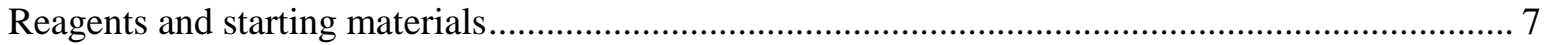

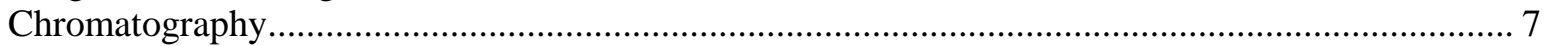

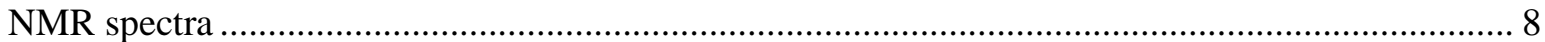

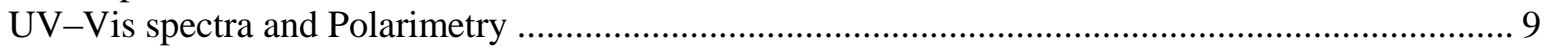

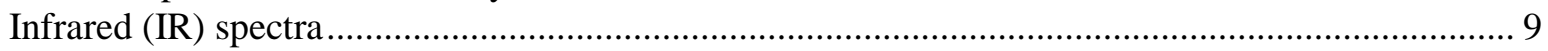

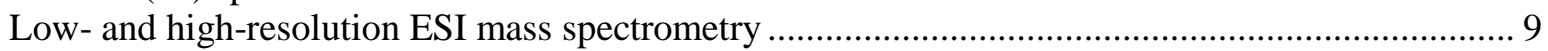

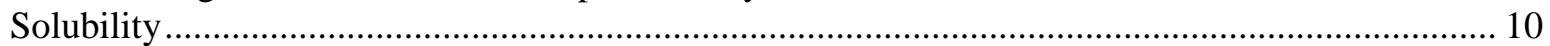

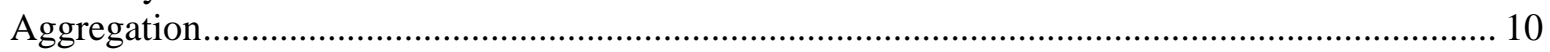

Materials and Methods - Biology ....................................................................................................... 11

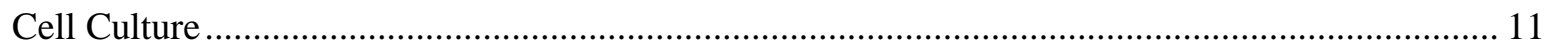

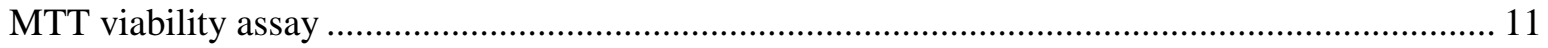

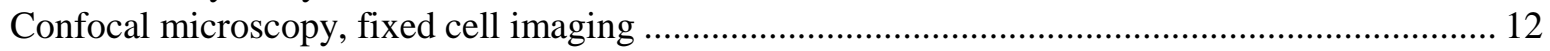

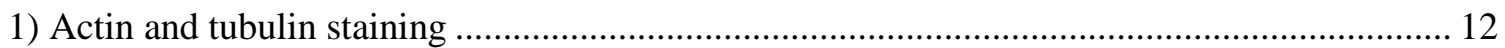

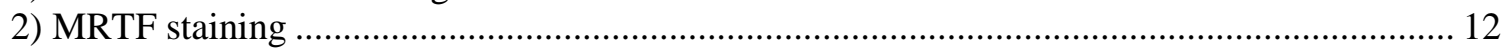

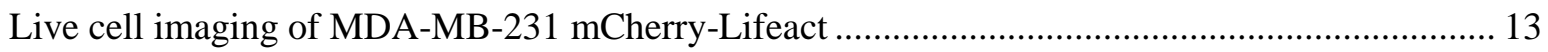

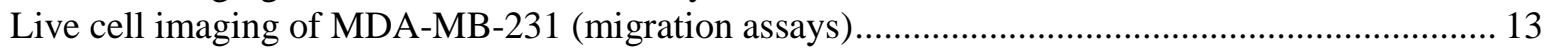

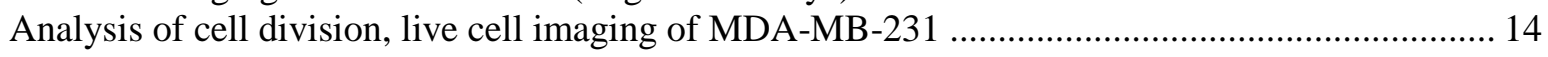

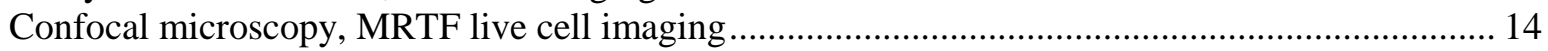

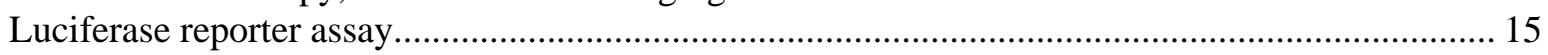

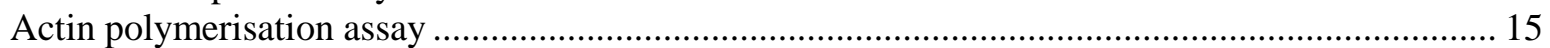

Supplementary Note 1: Chemical Synthesis and Characterisation ...................................... 19

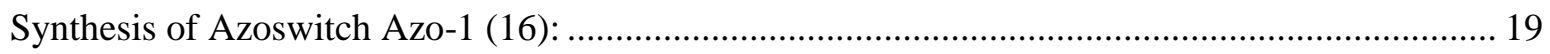

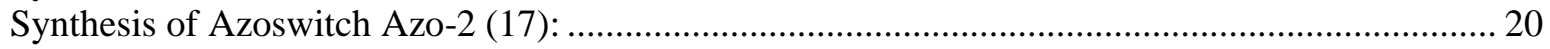

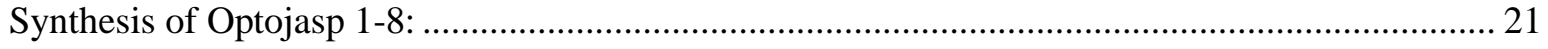

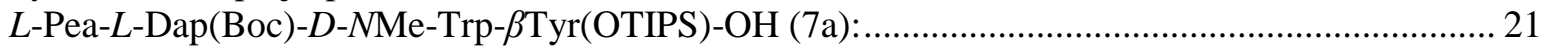

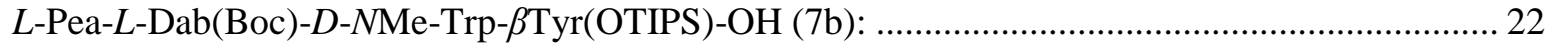

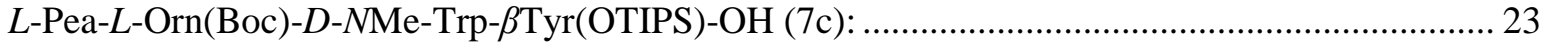

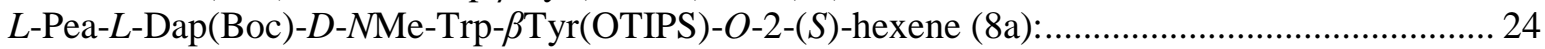

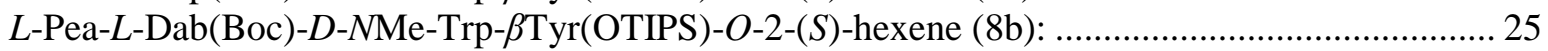

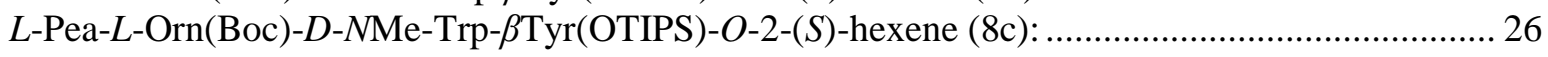

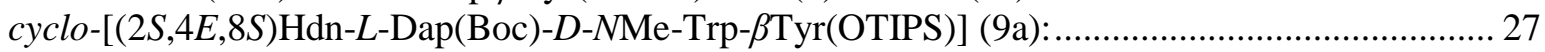

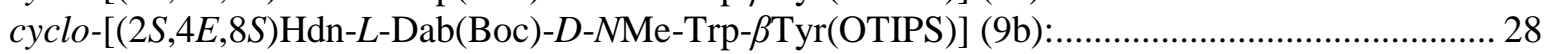

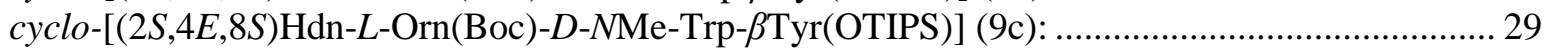

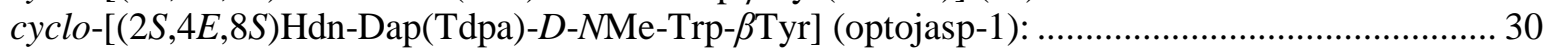

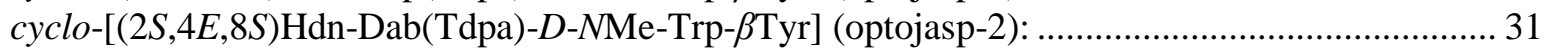

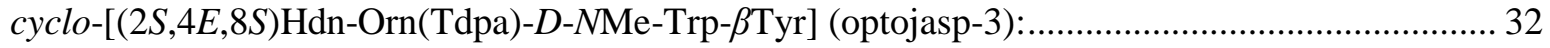

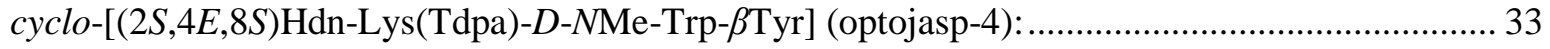

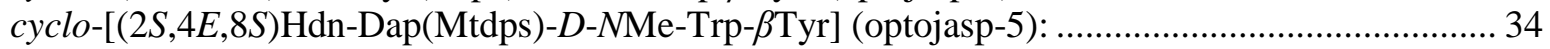

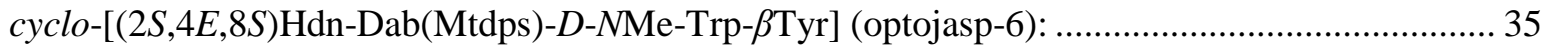

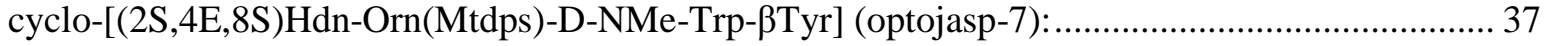

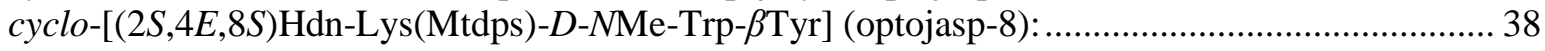

Supplementary Note 2: optojasp HPLC traces .........................................................................40

Supplementary Note 3: optojasp ${ }^{1}$ H-NMRs................................................................... 42

Supplementary Note 4: optojasp E/Z-isomer UV-VIS spectra .....................................46 


\section{Supplementary Figures}
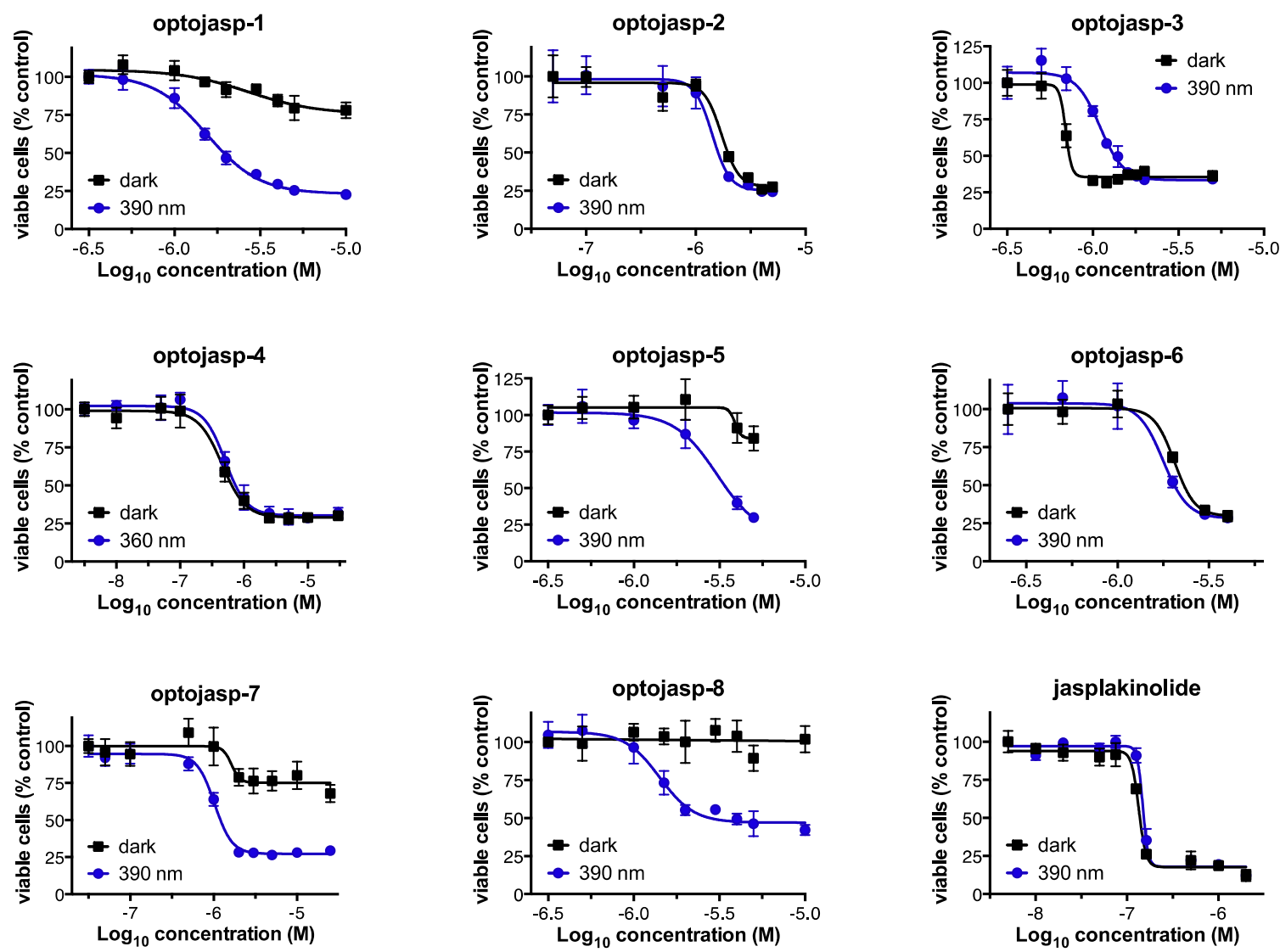

Figure S1. Light-dependent cytotoxicity screening of optojasps, related to Figure 3. Cytotoxicity profiles of optojasps were assessed in the dark and upon pulsed illumination with indicated wavelengths of light (chosen as optimal for cis-isomerisation of each derivative) using $75 \mathrm{~ms}$ light pulses every $15 \mathrm{~s}$ delivered using a 24-LED array placed under the 96-well-plate as previously described, ${ }^{\text {S1 }}$ by MTT assay in HeLa cells after $45 \mathrm{~h}$ treatment. Results are given as mean \pm SD. 


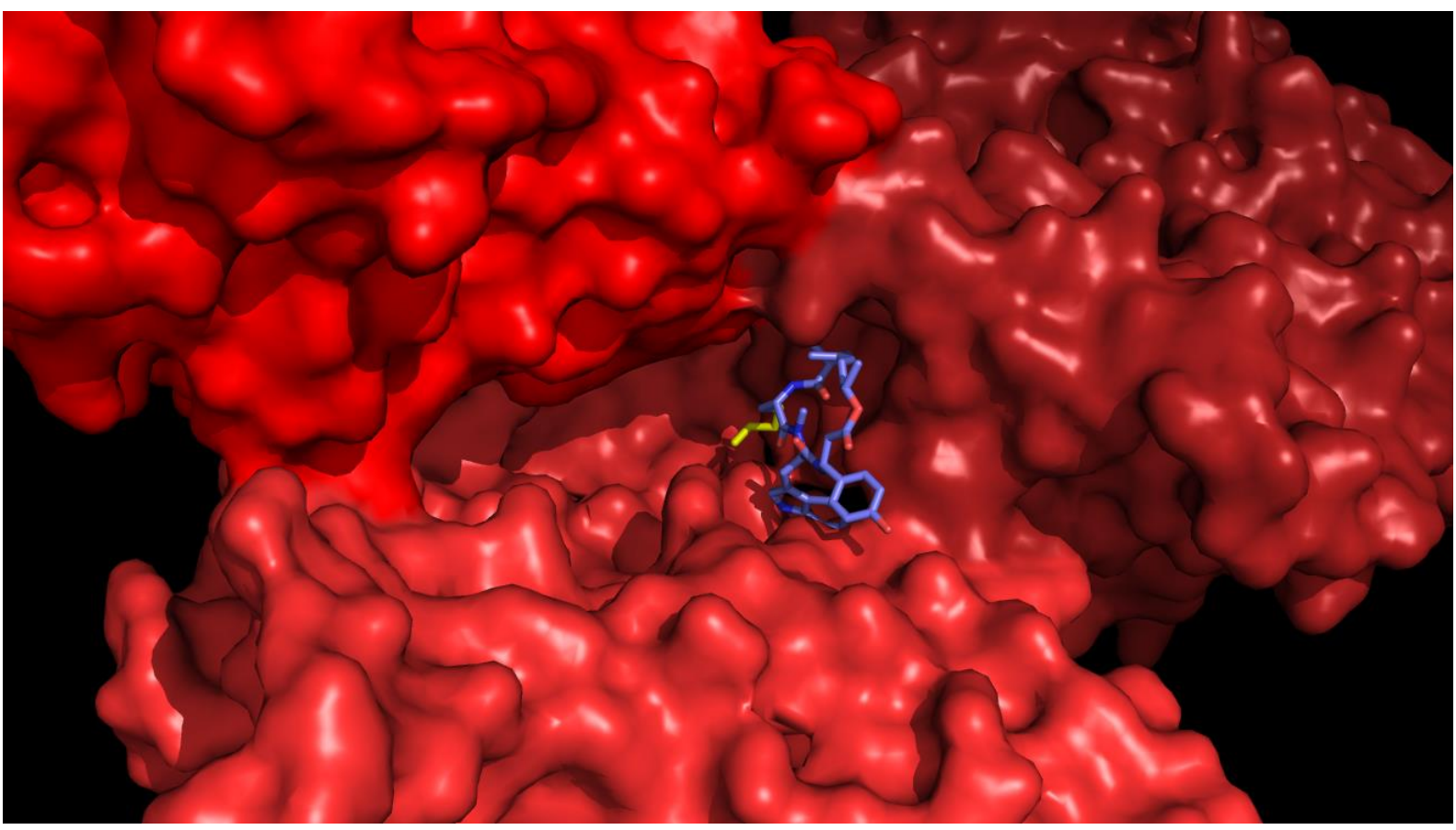

Figure S2. Illustration of the anticipated binding pocket of the optojasps. Shown is the localized binding position of Boc-deprotected jaspamide analog 9d (blue, oxygen atoms rendered in pink) bound to its binding site in Factin at the contacting edge of three actin monomers (three shades of red, PDB: 5OOC). ${ }^{\mathrm{S}}$ Note the complex cavity addressed by the direction of the Lys side chain (yellow).

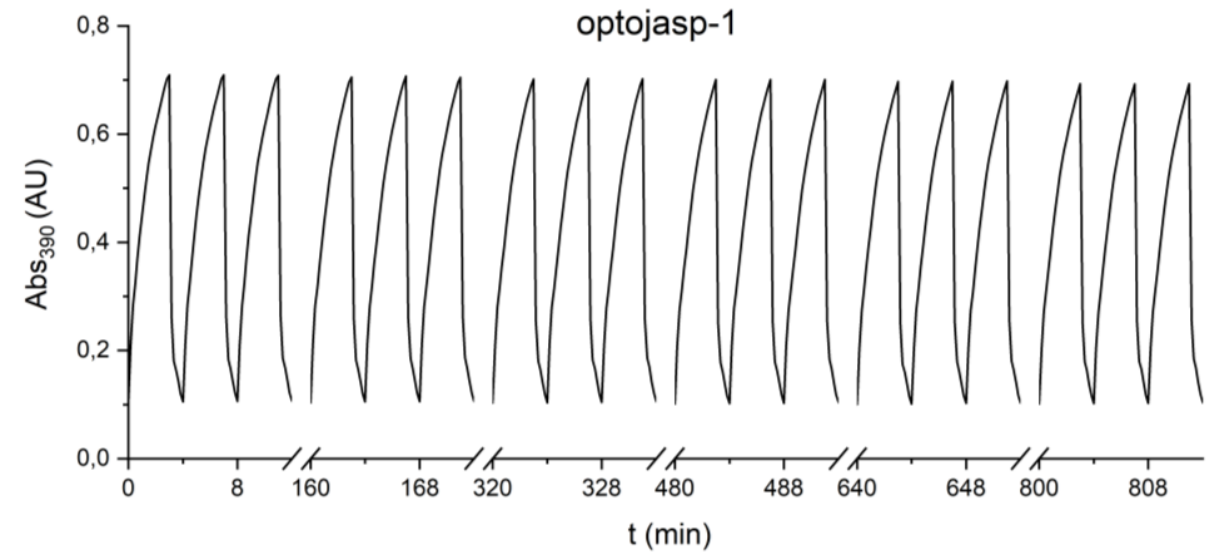

Figure S3. Photoswitching reversibility of optojasp-1 monitored by absorption at $390 \mathrm{~nm}$. One cycle of 4 minutes containing 3 minutes of $470 \mathrm{~nm}$ light pulses of $1 \mathrm{~s}$ every $10 \mathrm{~s}$ and 1 minute of $390 \mathrm{~nm}$ light pulses of $1 \mathrm{~s}$ every $10 \mathrm{~s}$. 

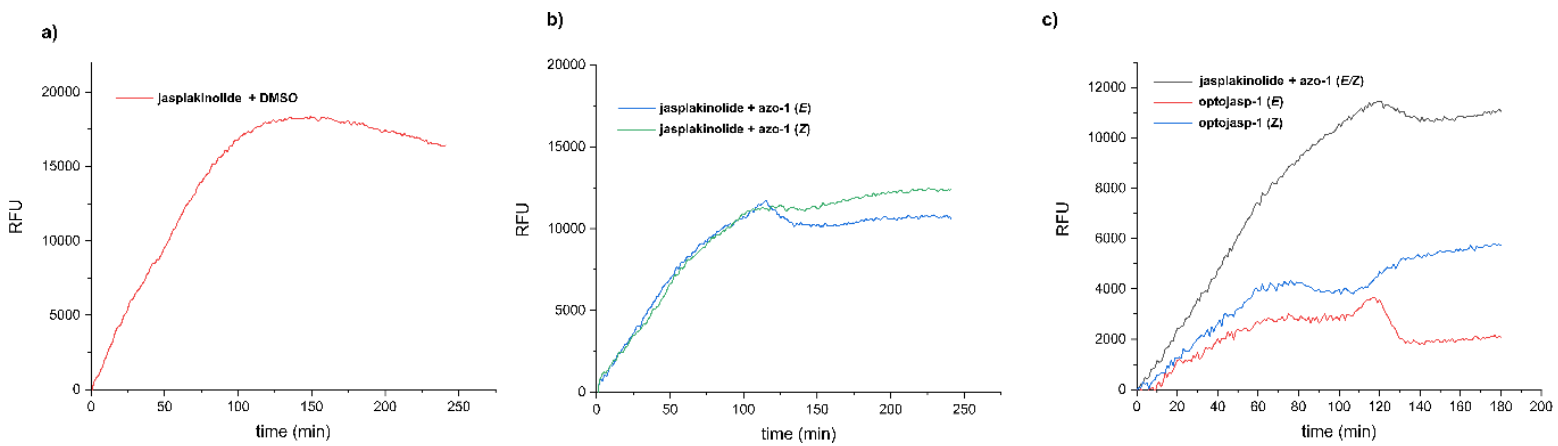

Figure S4. Curves of in vitro actin polymerization assay. a) Induced actin polymerization for pure jasplakinolid without optojasps or azo dye. b) Comparison of induced actin polymerization for jasplakinolid together with $(E)$ - or $(Z)$-isomer of azo-1. c) Comparison of induced actin polymerization of jasplakinolid + azo-1 (mean value of $(E)$ - and $(Z)$-isomer) with $(E)$ - and $(Z)$-isomer of optojasp-1.

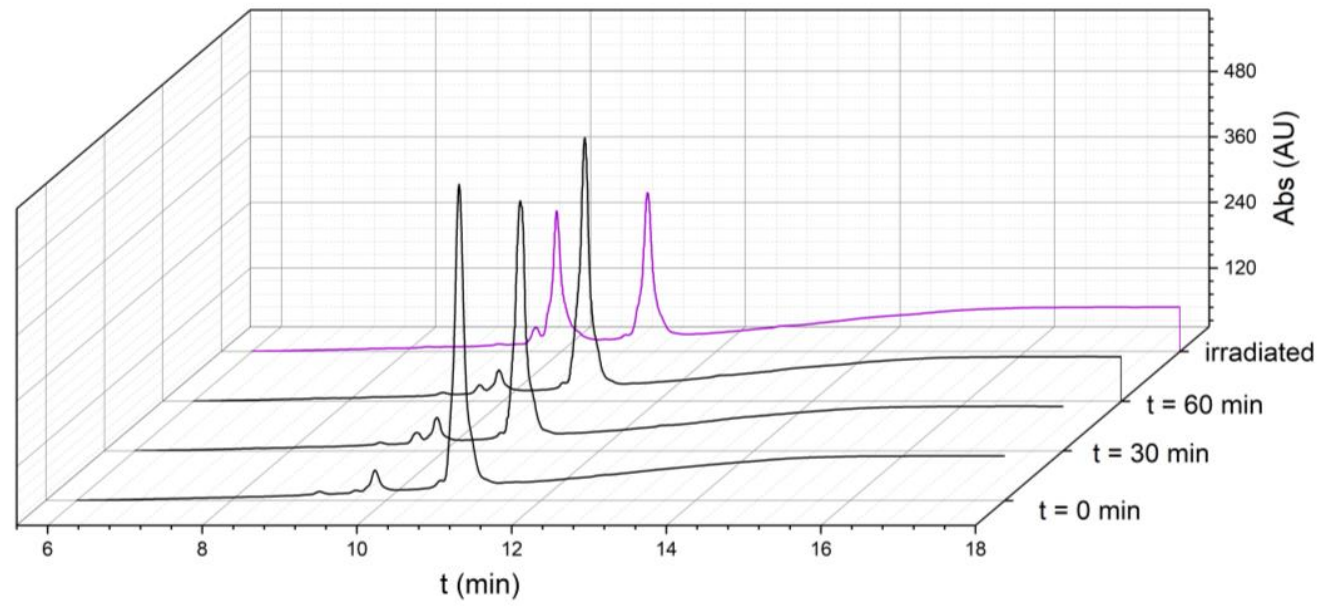

Figure S5. Change of $(E)$ - to $(Z)$ - optojasp-1 during in vitro actin polymerization assay monitored by HPLC $\left(\mathrm{t}_{\mathrm{R}},(Z)=10.18 \mathrm{~min}, \mathrm{t}_{\mathrm{R}},(E)=11.17 \mathrm{~min}\right)$. Samples taken from assay at $\mathrm{t}=0 \mathrm{~min}, 30 \mathrm{~min}$ and $60 \mathrm{~min}$. After completion of the assay an additional sample was irradiated at $390 \mathrm{~nm}$ for $1 \mathrm{~s}$ to show isomerisation to (Z)-Isomer. 


\section{Supplementary Video Material}

Movie 1. MDA-MB-231-mCherry:Lifeact cells show normal motility and cell morphology when treated with trans optojasp-1 $(5 \mu \mathrm{M})$.

Movie 2. MDA-MB-231-mCherry:Lifeact cells stop migrating and round up following the treatment with optojasp-1 $(5 \mu \mathrm{M})$ in combination with $405 \mathrm{~nm}$ light illumination (illumination time indicated by the blue marker at top right).

Movie 3. MDA-MB-231 cell motility in the presence of optojasp-1 $(4 \mu \mathrm{M})$ is consistent with cell migration without compound treatment. Selected cells (left panel) were tracked and their paths plotted (right panel) with starting coordinates for each cell set to $(\mathrm{X}=0, \mathrm{Y}=0)$.

Movie 4. MDA-MB-231 cell motility in the presence of optojasp-1 $(4 \mu \mathrm{M})$ is dramatically slowed down (reduction of cell speed and distance travelled) upon illumination with $390 \mathrm{~nm}$ light (LED).

Movie 5. Normal cell division in MDA-MB-231 cells treated with optojasp-1 (2.5 $\mu \mathrm{M})$ but without illumination with $390 \mathrm{~nm}$.

Movie 6. Perturbation of cell division in MDA-MB-231 cells treated with optojasp-1 $(2.5 \mu \mathrm{M})$ with $390 \mathrm{~nm}$ (LED) illumination - dividing cells do not complete cytokinesis and the two prospective daughter cells (indicated with arrowheads) reunite.

Movie 7. HUVEC cells expressing fluorescent MRTF:mCherry protein treated with cosolvent only and exposed to $405 \mathrm{~nm}$ illumination in the ROI indicated by the white rectangle display retention of MRTF in the cytoplasm without nuclear translocation for the duration of the experiment.

Movie 8. HUVEC cells expressing fluorescent MRTF:mCherry protein treated with optojasp5 and exposed to $405 \mathrm{~nm}$ illumination in the ROI indicated by the white rectangle. Rapid nuclear translocation of MRTF occurs in the selected cell whereas the neighbouring cell retains the cytosolic localisation of its MRTF for the duration of the experiment. 


\section{Materials and Methods - Chemistry}

\section{Reagents and starting materials}

All reagents and solvents were purchased from commercial sources (Acros, Alfa Aesar, ChemPur, Fluka, GL Biochem (Shanghai), Novabiochem, Sigma-Aldrich, Strem Chemicals, TCI Europe N.V., VWR) and were used without further purification unless noted otherwise. All solvents, when not purchased in suitable purity or dryness, were distilled using standard methods, ${ }^{\mathrm{S} 3}$ or passed through alumina columns (Innovative Technology, solvent purification system): tetrahydrofuran (THF) was distilled under a $\mathrm{N}_{2}$ atmosphere from $\mathrm{Na}$ /benzophenone before use; dichloromethane $\left(\mathrm{CH}_{2} \mathrm{Cl}_{2}\right)$ was distilled under a $\mathrm{N}_{2}$ atmosphere from $\mathrm{CaH}_{2}$ before use; and other dry solvents such as toluene and dimethylformamide (DMF) obtained in HPLC quality and passed through a solvent purification system (Pure Solv, Innovative Technology, Inc., USA) by applying $\mathrm{N}_{2}$ overpressure right before use. Commercial-grade distilled $(i \operatorname{Pr})_{2} \mathrm{NEt}(\mathrm{VWR})$ was used without additional processing. 2-Chlorotrityl chloride resin (100200 mesh; $1.6 \mathrm{mmol} \cdot \mathrm{g}-1)$ was purchased from Iris Biotech GmbH. $(S)$-Hex-5-en-2-ol (14), Fmoc-Lys(Boc)-OH (12d) and Fmoc-Orn(Boc)-OH (12c) were purchased from Sigma Aldrich. Known Fmoc-Dab(Boc)-OH (12b) and Fmoc-Dap(Boc)-OH (12a) were prepared according to literature procedures ${ }^{\mathrm{S} 4}$ followed by Boc-protection using standard methods. Fmoc- $\beta$ Tyr(TIPS)-OH (5), Fmoc- $N$-MeD-Trp-OH (11) and (S)-2,4-Dimethyl-4-pentenoic acid (13) were prepared according to literature procedures. ${ }^{\mathrm{S} 5}$ Known cyclo- $[(2 S, 4 E, 8 S) \mathrm{Hdn}-L-$ Lys(Boc)- $D$-NMe-Trp- $\beta$ Tyr(OTIPS)] (9d) was prepared according to a literature procedures. $^{\mathrm{S} 6}$

Deionized water was used for all experiments. All compounds intended for biological testing were purified using CHROMABOND-columns (1 mL, $100 \mathrm{mg}$ C18 silica gel, MachereyNagel, Düren, Germany) to remove solvent residues and salts.

Synthetic procedures are described in Supplementary Note 1.

\section{Chromatography}

Reaction progress was monitored by TLC on precoated, Merck Silica gel 60 F254 aluminabacked plates. TLC chromatograms were first visualized by UV-A or UV-B irradiation at 254 or $320 \mathrm{~nm}$, followed by staining with aqueous ninhydrin, $\mathrm{KMnO}_{4}$, or ceric ammonium molybdate solution, and gentle heating. Primary and secondary amines were detected with ninhydrin (6\% in EtOH). 
Flash silica gel chromatography was performed using silica gel $\left(\mathrm{SiO}_{2}\right.$, particle size $\left.40-63 \mu \mathrm{m}\right)$ purchased from Macherey \& Nagel, Düren (Germany) under a pressure of 0.3-0.5 bar.

Analytical HPLC was performed on a Shimadzu machine consisting of a LC-10AT (Pump), DGU-14AT (autosampler), CTO-10AC (column oven), C18 Gravity (precolumn), Nucleodur C18 Gravity $5 \mu \mathrm{m}$ (column), RF-10A (fluorescence detector), SDP-10A (UV/VIS-detector) und SCL-10A (controller). Evaluation was performed with Chromeleon (software). The gradient was started at $10 \% \mathrm{MeCN}$ (with $0.1 \%$ TFA) in $\mathrm{H}_{2} \mathrm{O}$ (with $0.1 \%$ TFA) with a flow of $1 \mathrm{~mL} \cdot \min -1$, and the proportion of organic component was linearly increased after $1 \mathrm{~min}$ to 95\% over a period of $10 \mathrm{~min}$ and then kept at that ratio for a period of $9 \min (\operatorname{method} A)$. Alternatively the gradient was started at 50\% MeCN (method B). Thirdly, a gradient was started at $10 \% \mathrm{MeCN}$ (with $0.1 \%$ TFA) in $\mathrm{H}_{2} \mathrm{O}$ (with $0.1 \%$ TFA) with a flow of $1 \mathrm{~mL} \cdot \mathrm{min}-1$, and the proportion of organic component linearly increased to $95 \%$ over a period of $10 \mathrm{~min}$ and then kept at that ratio for a period of $5 \min (\operatorname{method} C)$. Alternatively, LC-MS analysis was performed on a Shimadzu (HPLC) consisting of a DGU-14A (degasser), LC-10AT VP (pumps), SIL-20AT VP (autosampler), CTO-10AC VP (column oven), C18 Gravity (precolumn), Nucleodur C18 ISIS $3 \mu \mathrm{m}$ (column), SPD-10A VP (UV/VIS-detector), SCL-10A VP (Controller), Acurate Post-Column Splitter (splitter), fitted to a Finnigan LCQ (ESI-MS). The gradient was started at $10 \% \mathrm{MeCN}$ (with $1.0 \% \mathrm{AcOH}$ ) in $\mathrm{H}_{2} \mathrm{O}$ (with $1.0 \% \mathrm{AcOH}$ ) with a flow of $1 \mathrm{~mL} \cdot \mathrm{min}-1$, and the proportion of organic component was linearly increased to $100 \%$ over a period of $10 \mathrm{~min}$ and then kept at that proportion for a period of $5 \mathrm{~min}(\operatorname{method} A)$. Alternatively the gradient was started at $30 \% \mathrm{MeCN}(\operatorname{method} B)$ or was started at $50 \% \mathrm{MeCN}$ (method $C$ ). In some cases, $E$ - and Z-azobenzene isomers were clearly separated. Traces of analytical HPLC analyses of final compounds are reproduced in Figure S3.

Preparative HPLC purification was performed on a Varian device consisting of a ProStar 215 (pump), ProStar 340 (UV/VIS-detector) and a ProStar 701 (collector). A VP250/21 Nucleodur C18 Gravity $5 \mu \mathrm{m}$ was used as column. As mobile phase a gradient of water and acetonitrile was applied.

\section{NMR spectra}

${ }^{1} \mathrm{H}$ - and ${ }^{13} \mathrm{C}-\mathrm{NMR}$ spectra were recorded on Bruker Avance I $250\left(250 \mathrm{MHz}\left({ }^{1} \mathrm{H}\right)\right.$ and $63 \mathrm{~Hz}$ $\left({ }^{13} \mathrm{C}\right)$ ), Bruker Fourier $300\left(300 \mathrm{MHz}\left({ }^{1} \mathrm{H}\right)\right.$ and $\left.75 \mathrm{~Hz}\left({ }^{13} \mathrm{C}\right)\right)$, Bruker Avance III 400 (400 $\mathrm{MHz}\left({ }^{1} \mathrm{H}\right)$ and $\left.100 \mathrm{MHz}\left({ }^{13} \mathrm{C}\right)\right)$, Bruker Avance III HD $500\left(500 \mathrm{MHz}\left({ }^{1} \mathrm{H}\right)\right.$ and $100 \mathrm{MHz}$ $\left.\left({ }^{13} \mathrm{C}\right)\right)$, and Bruker $\mathrm{AC} 600\left(600 \mathrm{MHz}\left({ }^{1} \mathrm{H}\right)\right.$ and $\left.150 \mathrm{MHz}\left({ }^{13} \mathrm{C}\right)\right)$. Chemical shifts are expressed 
in parts per million (ppm) and the spectra are calibrated to residual solvent signals of $\mathrm{CDCl}_{3}$ (7.26 ppm $\left({ }^{1} \mathrm{H}\right)$ and $77.0 \mathrm{ppm}\left({ }^{13} \mathrm{C}\right)$ ), DMSO $\left(2.50 \mathrm{ppm}\left({ }^{1} \mathrm{H}\right)\right.$ and $\left.39.43 \mathrm{ppm}\left({ }^{13} \mathrm{C}\right)\right)$, respectively. Coupling constants are given in Hertz $(\mathrm{Hz})$ and the following notations indicate the multiplicity of the signals: s (singlet), $d$ (doublet), $t$ (triplet), q (quartet), qui (quintet), sxt (sextet), m (multiplet), br (broad signal). Owing to the presence of $E$ and $Z$ isomers of some compounds containing an azobenzene functionality, more signals were observed in the ${ }^{1} \mathrm{H}$ and

${ }^{13} \mathrm{C}$ spectra than would be expected for a single isomer, depending on illumination history. Signals for the major $E$ isomer are reported. Signals for the less stable Z-isomers are indicated where available. Signal identity and peak assignments were verified by 2D-NMR experiments (COSY, TOCSY, HSQC and HMBC) whenever necessary. NMR spectra are displayed in Supplementary Note 3.

\section{UV-Vis spectra and Polarimetry}

UV-Vis spectra were recorded using a JASCO V-730 UV-Visible Spectrophotometer with Helma SUPRASIL precision cuvettes (5 mm light path). All compounds were dissolved as $10 \mathrm{mM}$ stock solutions in DMSO and diluted to the given concentrations using cosolvents and buffers as indicated. Switching was achieved by using a blue LED (390 nm) UV-spectra of all compounds are reproduced in Figure S4.

Optical rotations were measured in a Jasco Polarimeter P 2000 at 589 nm, with values given in deg. $\mathrm{cm}^{2} \cdot \mathrm{g}^{-1}$ and concentrations $\mathrm{c}$ given in $\mathrm{g} / 100 \mathrm{~mL}$.

\section{Infrared (IR) spectra}

Fourier transform infrared spectroscopy (FT-IR) spectra were obtained with an IR-Affinity-1 from Shimadzu (ATR, neat or as a thin film). Wave numbers are reported in $\mathrm{cm}^{-1}$.

\section{Low- and high-resolution ESI mass spectrometry}

Low- and high-resolution ESI mass spectra were obtained on a Thermo-Finnigan LCQ (LR) and Bruker Maxis Impact (HR) spectrometers operating in either positive or negative ionization modes, respectively, fitted to Shimadzu AL-10 (LR-ESI-MS) or Dionex Ultima 3000 HPLC systems (HR-ESI-MS). 


\section{Solubility}

To analyze the solubility, the light scattering at $800 \mathrm{~nm}$ was measured on a V 630 spectrophotometer from Jasco in $5 \mathrm{~mm}$ cells at $25^{\circ} \mathrm{C}$. Saturated solutions of optojasp-1 were examined as $(E)$ - isomer (dark) and as $(Z)$ - isomer $(390 \mathrm{~nm})$ and are shown in Table S1. For this purpose, stock solutions of both isomers of optojasp-1 were prepared in acetonitrile $(200 \mu \mathrm{M})$ and mixed with PBS buffer $(6 \%$ ACN in PBS). The suspensions were stirred at 25 ${ }^{\circ} \mathrm{C}$ for one hour and then filtered through a syringe filter $(0.20 \mu \mathrm{m})$. The sample of the $(Z)-$ isomer was irradiated every $10 \mathrm{~s}$ for $1 \mathrm{~s}(390 \mathrm{~nm})$. The basic value of the saturated solutions prepared in this way was measured. The $(E)$ - isomer was then irradiated $(390 \mathrm{~nm})$ for $1 \mathrm{~s}$ every $10 \mathrm{~s}$ for $30 \mathrm{~min}$, the $(Z)$ - isomer stored in the dark for $14 \mathrm{~h}$. The samples were measured again to analyze potential particle formation. In order to force particle formation, the samples were mixed with $10 \mu \mathrm{L}$ of the respective stock solution and analyzed again.

Table S1. Solubility measurement of optojasp-1 by determination of light scattering at $800 \mathrm{~nm}$.

\begin{tabular}{cc}
\hline Entry & Absorbance [AU] \\
\hline$(\boldsymbol{E})$-Isomer (sat.) & $6.0 \mathrm{E}-3$ \\
$(\boldsymbol{E}) \rightarrow(\boldsymbol{Z})$ & $4.2 \mathrm{E}-3$ \\
$(\boldsymbol{Z})+$ optojasp-1 & $36.9 \mathrm{E}-3$ \\
$(\boldsymbol{Z})$-Isomer (sat.) & $4.4 \mathrm{E}-3$ \\
$(\boldsymbol{Z}) \rightarrow(\boldsymbol{E})$ & $6.3 \mathrm{E}-3$ \\
$(\boldsymbol{E})+$ optojasp-1 & $38.1 \mathrm{E}-3$ \\
\hline
\end{tabular}

\section{Aggregation}

Possible occurrence of aggregates was examined by UV-VIS. By changing the concentration over several orders of magnitude, the aggregation can be influenced, which occurs especially in the range between $1 \mathrm{mM}$ and $1 \mu \mathrm{M} .{ }^{\mathrm{S} 7}$ Due to the aggregation, a shift in the absorption maximum can be observed in dyes. ${ }^{\mathrm{S} 8}$ For optojasp-1, the $(E)$ - as well as the $(Z)$ - isomer in aqueous solution $\left(\mathrm{CH}_{3} \mathrm{CN} / \mathrm{PBS}, 1: 2\right)$ a concentration series was prepared and analyzed and are shown in Table S2. No significant shift in the absorption maximum was observed.

Table S2. Aggregation measurement of optojasp-1.

\begin{tabular}{ccc}
\hline $\mathbf{c}[\mathbf{m M}]$ & $\boldsymbol{\lambda}_{\text {max },(\mathbf{E})}[\mathrm{nm}]$ & $\boldsymbol{\lambda}_{\text {max },(\mathbf{Z})}[\mathrm{nm}]$ \\
\hline $\mathbf{0 . 5}$ & 360 & 440 \\
$\mathbf{0 . 1}$ & 360 & 441 \\
$\mathbf{0 . 0 5}$ & 360 & 441 \\
$\mathbf{0 . 0 1}$ & 360 & 439 \\
$\mathbf{0 . 0 0 5}$ & 358 & 439 \\
\hline
\end{tabular}




\section{Materials and Methods - Biology}

\section{Cell Culture}

HeLa (ACC-57, DSMZ), MDA-MB-231 (ACC-732, DSMZ) and mCherry-Lifeact MDAMB-231 cells (gift from A. Akhmanova, Utrecht University) were grown in Dulbecco's modified Eagle's medium (DMEM, PAN-Biotech P04-03550) supplemented with $10 \%$ heatinactivated fetal calf serum, $100 \mathrm{U} / \mathrm{mL}$ penicillin and $100 \mu \mathrm{g} / \mathrm{mL}$ streptomycin (Sigma Aldrich, P4333). Cells were grown at $37^{\circ} \mathrm{C}$ in a $10 \% \mathrm{CO}_{2}$ atmosphere. Prior to assays, cells were transferred to phenol red free medium (DMEM, PAN-Biotech P04-03591). Human Umbilical Vein Endothelial Cells (HUVECs) were purchased from Promocell (Heidelberg, Germany, C-12200) and grown in Endothelial Cell Growth Medium (PELO Biotech, Planegg, Germany, PB-MH-100-2199) supplemented with 10\% heat-inactivated fetal calf serum, $100 \mathrm{U} / \mathrm{mL}$ penicillin and $100 \mu \mathrm{g} / \mathrm{mL}$ streptomycin (Sigma Aldrich, $\mathrm{P} 4333$ ), at $37^{\circ} \mathrm{C}$ in a $5 \%$ $\mathrm{CO}_{2}$ atmosphere.

\section{MTT viability assay}

Mitochondrial dehydrogenase activity in HeLa cells was quantified by spectrophotometrically measuring the reduction of 3-(4,5-dimethylthiazol-2-yl)-2,5-diphenyl tetrazolium bromide (MTT) to formazan, according to standard protocols. ${ }^{\text {S9 }}$ Briefly, HeLa cells were seeded on 96well microtiter plates at 5000 cells/well. After $24 \mathrm{~h}$, cells were treated with the test compounds, shielded from ambient light inside light-proof boxes, and exposed to appropriate light regimes (typically pulses of $75 \mathrm{~ms}$ every $15 \mathrm{~s}$, if not indicated otherwise) by using LEDs mounted in an DISCO setup ${ }^{\mathrm{S} 1}$ approx. 0.5 inch on top of each well. The LEDs used (Roithner Lasertechnik, Vienna, Austria) had an input power of approx. $80 \mathrm{~mW}(20 \mathrm{~mA}, 4 \mathrm{~V})$, a spectral width of $30 \mathrm{nM}$ (FWHM), and an approx. light output of $3 \pm 2 \mathrm{Cd}$ or $1-5 \mathrm{~mW} / \mathrm{cm}^{2}$ (depending on wave length). ${ }^{\mathrm{S} 10}$ In the MTT experiments $1 \% \mathrm{DMSO}$ and $2 \% \mathrm{MeCN}$ were present as cosolvents for all compounds at all the concentrations tested, to ensure full solubility of all compounds and comparability of the data. Under these conditions, control cells were growing normally. Following $48 \mathrm{~h}$ of treatment, cells were incubated with $0.5 \mathrm{mg} / \mathrm{mL}$ MTT for 3 hours at $37{ }^{\circ} \mathrm{C}$. Formazan crystals were then dissolved in DMSO, and formazan absorbance was determined at $550 \mathrm{~nm}$ with a FLUOstar Omega microplate reader (BMG Labtech). For statistical analysis the absorbance readings for untreated controls (cosolvent only) were set as $100 \%$ of viable cells. Results are given as the mean percentage of viable cells relative to these 
controls \pm standard deviation (SD) from a representative experiment out of three independent trials performed in sextuplicates. Graphical representations and statistical analysis of the data were performed using GraphPad Prism (GraphPad Software, La Jolla, CA, USA). Fourparameter curve fitting for sigmoidal dose-response curves with a variable slope was used to determine the $\mathrm{EC}_{50}$ values, unless sigmoidal curve fitting was not appropriate in which case a linear regression fit was used instead. When the $50 \%$ of cell viability was not reached, $\mathrm{EC}_{50}$ values were marked as " $>\mathrm{X} \mu \mathrm{M}$ " indicating the highest concentration $(\mathrm{X} \mu \mathrm{M})$ tested.

\section{Confocal microscopy, fixed cell imaging}

\section{1) Actin and tubulin staining}

HeLa cells were seeded on coverslips one day prior to the experiment. Dilutions of optojasps were applied in the dark and cells were subsequently shielded from ambient light or exposed to the appropriate light regimes (typically $390 \mathrm{~nm}$ pulses of $75 \mathrm{~ms}$ every $15 \mathrm{~s}$ ) for 5 or $18 \mathrm{~h}$. Then, cells were washed with pre-warmed PBS, and cell extraction buffer (80 mM PIPES pH 6.8; $1 \mathrm{mM} \mathrm{MgCl}_{2}, 5 \mathrm{mM}$ ethylene glycol tetraacetic acid (EGTA) dipotassium salt and $0.5 \%$ Triton X-100) was added to remove actin monomers. After $30 \mathrm{~s}$ of extraction, cells were fixed for $10 \mathrm{~min}$ with $0.5 \%$ glutaraldehyde. Following glutaraldehyde quenching with $0.1 \%$ $\mathrm{NaBH}_{4}$ in PBS for 7 min, coverslips were blocked with PBS containing 10\% fetal calf serum. Actin staining was performed using Phalloidin Alexa Fluor 488 or 546 (Molecular Probes A12379 and A22283 respectively). Tubulin immunostaining was performed using rabbit anti$\alpha$-tubulin antibody (Abcam, ab18251) and goat anti-rabbit secondary antibody with AlexaFluor 488 (ThermoFisher, A 11008). Coverslips were mounted with Roti-Mount FluorCare reagent (Carl Roth, HP20.1) containing DAPI for nuclear staining. Samples were analysed with Leica SP5 confocal microscope (Leica Microsystems, Mannheim, Germany). Acquired images were processed using ImageJ (National Institutes of Health, USA). Representative images are shown. White scale bars correspond to $20 \mu \mathrm{m}$.

\section{2) MRTF staining}

HUVECs were plated on 8-well ibiTreat $\mu$ slides (Ibidi, Martinsried, Germany) $48 \mathrm{~h}$ prior to the experiment. Working stocks of optojasp-5 were prepared one day prior to the experiment and stored in the dark at $37{ }^{\circ} \mathrm{C}$ overnight to ensure the trans isomer was quantitatively present at the start of experiment. Cells were treated with optojasp-5 for $1 \mathrm{~h}$ in medium containing 0.75\% DMSO to ensure full solubility. Application of the inhibitor was performed in the darkroom conditions, and for the duration of the experiment cells were maintained either in the dark or under pulsed illuminations with $390 \mathrm{~nm}$ light (75 ms pulses every $15 \mathrm{~s}$ ). Following 
the treatment, cells were fixed with $4 \%$ PFA and permeabilized with $0.5 \%$ Triton $X-100$. The immunostaining was performed following the blocking step with $10 \%$ goat serum. MRTF was visualized using mouse mAb against MRTF-A (G-8) from Santa Cruz (sc-390324) and goat anti-mouse AlexaFluor 488 secondary antibody (ThermoFisher, A-11001). F-actin was visualized with Rhodamine-phalloidin (Sigma Aldrich) and nuclei were stained with $0.5 \mu \mathrm{g} / \mathrm{ml}$ Hoechst 33342 (Sigma Aldrich). Cells were subsequently mounted with FluorSave reagent mounting media (Merck Millipore, Darmstadt, Germany). Images were acquired using a Leica SP8 confocal microscope and analysed using ImageJ (National Institutes of Health, USA). Representative images are shown. Nuclear levels of MRTF-A were determined via quantification of total MRTF-A signal intensity in relation to the intensity in Hoechst positive areas. Results are given as mean percentage of nuclear MRTF-A \pm SEM from 3 representative images acquired in 3 independent experiments. Significance was determined using unpaired Student t-tests, $\mathrm{p}$ value $<0.05$.

\section{Live cell imaging of MDA-MB-231 mCherry-Lifeact}

MDA-MB-231 cells stably expressing mCherry-Lifeact were plated on 8-well ibiTreat $\mu$ slides (Ibidi, Martinsried, Germany) and imaged twenty-four hours later using a Leica SP5 confocal microscope (Leica Microsystems, Mannheim, Germany). Prior to imaging, cells were treated with $5 \mu \mathrm{M}$ optojasp-1. Throughout the experiment samples were maintained at $37{ }^{\circ} \mathrm{C}$ in a $5 \% \mathrm{CO}_{2}$ atmosphere. Cells were imaged for $12 \mathrm{~h}$ using the $561 \mathrm{~nm}$ laser line with a frame rate of one image every $10 \mathrm{~min}$. Cells marked as "exposed to UV light" (movie 2) were first only imaged for $2 \mathrm{~h}$, then in addition to the imaging sequence cells were exposed to six UV light pulses of $30 \mathrm{~s}$ applied every $10 \mathrm{~min}$ (epifluorescence mode, DAPI excitation filter), and following $1 \mathrm{~h}$ of this UV-regime cells were imaged for a further $9 \mathrm{~h}$ with additional $405 \mathrm{~nm}$ diode laser line illuminations every $10 \mathrm{~min}$ (confocal laser-scanning mode) in order to maintain $c i s$-isomer state of the inhibitor. Image processing was performed using the opensource ImageJ software (National Institutes of Health, USA). White scale bars correspond to $40 \mu \mathrm{m}$.

\section{Live cell imaging of MDA-MB-231 (migration assays)}

MDA-MB-231 cells were plated on 8-well ibiTreat $\mu$-slides (Ibidi, Martinsried, Germany). Twenty-four hours later cells were treated with optojasp-1/3 using $0.25 \%$ DMSO and 1\% $\mathrm{MeCN}$ as cosolvents in order to ensure the solubility of the test compounds. Cells were imaged for $18-20 \mathrm{~h}$ at the frame rate of one image every $10 \mathrm{~min}$ using a bright-field $\mathrm{u}$-iMIC 
digital microscope with phase contrast (TiLL/Agilent, Gräfelfing, Deutschland). During imaging cells were maintained under $37{ }^{\circ} \mathrm{C}, 80 \%$ humidity and $5 \% \mathrm{CO}_{2}$, using an Ibidi incubation system (Ibidi $\mathrm{GmbH}$ ). Cells were imaged using a $650 \mathrm{~nm}$ light source and in between of the recording time points cells were maintained in the dark or under pulsed LED illuminations with $390 \mathrm{~nm}$ light at a rate of $75 \mathrm{~ms}$ pulse every $15 \mathrm{~s}$ as in cell culture experiments. Acquired movies were processed using ImageJ (National Institutes of Health, USA). Cells were tracked using Manual Tracking Plugin (National Institutes of Health, USA) and the cell trajectories were analysed using the Chemotaxis and Migration Tool (Ibidi Martinsried, Germany). For every experimental condition at least 15 cells were tracked and average accumulated distance and mean velocity were calculated. Only viable non-dividing cells were taken into account. Statistical analysis was performed using GraphPad Prism (Graph Pad Software, La Jolla, CA, USA). Results are expressed as mean \pm SD.

\section{Analysis of cell division, live cell imaging of MDA-MB-231}

Cell division of MDA-MB-231 cells was imaged using a bright-field iMIC digital microscope with phase contrast (TILL/Agilent, Gräfelfing, Germany). Cells seeded on 8-well ibiTreat $\mu$ slides (Ibidi, Martinsried, Germany) were treated with $2.5 \mu \mathrm{M}$ optojasp-1 (using $0.25 \%$ DMSO and 1\% MeCN as cosolvents) and exposed to $390 \mathrm{~nm}$ light pulsed illumination (75 ms every 15 s) or maintained in the dark. Samples were kept under $37{ }^{\circ} \mathrm{C}, 80 \%$ humidity and $5 \%$ $\mathrm{CO}_{2}$ during the entire experiment. Images were taken at a frame rate of 1 image/10 min using a $650 \mathrm{~nm}$ light source. Experiment was performed independently three times and representative movies of dividing cells are shown. Image processing was done using ImageJ (National Institutes of Health, USA). White scale bars correspond to $40 \mu \mathrm{m}$.

\section{Confocal microscopy, MRTF live cell imaging}

HUVEC cells were plated on 8-well ibiTreat $\mu$-slides (Ibidi, Martinsried, Germany) coated with $50 \mu \mathrm{g} / \mathrm{ml}$ fibronectin in sterile $\mathrm{H}_{2} \mathrm{O}$. After $24 \mathrm{~h}$ cells were transiently transfected with a plasmid encoding for murine MRTF-A, which was C-terminally fused to mCherry and expressed from the commercially available pcDNA 3.1 vector after insertion via KpnI and NotI restriction sites. Cells were transfected using the Targefect-HUVEC ${ }^{\mathrm{TM}}$ kit (Targeting Systems, El Cajon, CA, USA) according to the manufacturer's instructions. Cells were imaged twenty-four hours later using a confocal Leica SP8 microscope (Leica Microsystems, Mannheim, Germany). During imaging cells were maintained at $37^{\circ} \mathrm{C}$ in a $5 \% \mathrm{CO}_{2}$ atmosphere. Cells were treated with $500 \mathrm{~nm}$ optojasp-5 with addition of $0.75 \%$ DMSO, or 
else with cosolvent only, and imaged briefly (20 min) before compound activation. Then, cells were imaged for $50 \mathrm{~min}$ with $561 \mathrm{~nm}$ laser at the rate of two frames per minute, with alternating phases of pulsed photoisomerisation illuminations at $405 \mathrm{~nm}$ within the selected region of interest (ROI, $25 \mu \mathrm{m} \times 55 \mu \mathrm{m}$ ). Images were processed using Image J (National Institutes of Health, USA).

\section{Luciferase reporter assay}

One day prior to treatment, HUVECs were transfected with pGL4.74 [hRluc/TK] Renilla luciferase control vector and pGL4.34 [luc2P/SRF-RE/Hygro] construct encoding Firefly luciferase under the control of the promoter containing serum response elements. Vectors were purchased from Promega and transfection was performed using Targefect-HUVEC (Targeting Systems) according to the manufacturer's instructions. Cells were treated for $6 \mathrm{~h}$ with optojasp-5 (or jasplakinolide as a positive control), and cultured either in the dark or under pulsed illumination with $390 \mathrm{~nm}$ light (75 ms pulses every $15 \mathrm{~s}$ ) with $0.75 \%$ DMSO as cosolvent. The working stocks of optojasp-5 were prepared one day prior to the experiment and stored in the dark at $37{ }^{\circ} \mathrm{C}$ overnight to ensure the trans isomerisation state of the test compounds. Following $6 \mathrm{~h}$ of treatment cells were lysed and reporter gene assay was performed using the Dual Luciferase Reporter Assay System (Promega) on a Berthold Orion II Luminometer. Transfection efficiencies were normalized to the activity of Renilla luciferase. Results are given as the mean relative Firefly luciferase activity \pm SEM from 3 representative experiments performed in duplicates. Graphical representations and statistical analysis of the data were performed using GraphPad Prism (GraphPad Software, La Jolla, CA, USA).

\section{Actin polymerisation assay}

For the in vitro actin polymerization assay pyrene labelled muscle actin assay from Cytoskeleton, Inc was used. The supplier's protocols were followed, with specific modifications (Actin Polymerization Biochem Kit ${ }^{\mathrm{TM}}$, Cat. \# BK003). Dye to protein (G-actin) ratio was 0.6. https://www.cytoskeleton.com/pdf-storage/datasheets/bk003.pdf.

G-actin was diluted to a concentration of $5 \mu \mathrm{M}$ in G-buffer and secondary stocks of compounds were pipetted to give a final concentration of $20 \mu \mathrm{M}$, keeping the final concentration of DMSO at $2 \%$. After shaking for 10 seconds, fluorescence intensity was 
measured in a plate reader every 60 seconds over $4 \mathrm{~h}$, at $37^{\circ} \mathrm{C}$, using excitation at $360 \mathrm{~nm}$ and detection at $410 \mathrm{~nm}$. Cis/trans-ratios remained unaffected using these conditions (HPLC control, see Figure S5). Experiments were done in duplicates and normalized to fluorescence emission of G-actin in non-polymerizing buffer, followed over the course of experiment. Slopes were calculated in the linear range of plots and compared in relative to jasplakinolide.

\section{Detailed protocol information:}

Test compounds were dissolved in non-polymerizing buffer provided by the supplier as " $\mathrm{G}$ Buffer" (5 mM Tris- $\mathrm{HCl} \mathrm{pH} 8.0,0.2 \mathrm{mM} \mathrm{CaCl}_{2}, 0.2 \mathrm{mM}$ ATP) by pipetting DMSO primary stock solutions of test compounds to give secondary stock solutions. Black, 384-well plates were used for measurement.

\section{G-Buffer preparation:}

1. An aliquot of ATP (\# BSA04, Cytoskeleton, Inc.) was kept on ice until it liquified. (Previously stored at $-80^{\circ} \mathrm{C}$ ). After thawing it was centrifuged for $5 \mathrm{~s}$ in a microcentrifuge to collect the liquid at the bottom of the tube.

2. G buffer was prepared by adding $2.0 \mu \mathrm{L}$ ATP (\# BSA04, Cytoskeleton, Inc.) per $1.0 \mathrm{~mL}$ of "General Actin Buffer" (\# BSA01, Cytoskeleton, Inc.).

Pyrene-G-actin solution preparation:

$1.1 \mathrm{~mL}$ of cold water was added to $1 \mathrm{mg}$ of pyrene labelled G-actin (\# AP05 Cytoskeleton, Inc.) and the mixture was divided to aliquots of $5 \mu \mathrm{L}$. Aliquots were frozen in liquid nitrogen and stored at $-80{ }^{\circ} \mathrm{C}$.

2. G-actin stock solution was prepared by dissolving an aliquot of pyrene actin $(5 \mu \mathrm{L})$ in $356 \mu \mathrm{L}$ of cooled $\mathrm{G}$ buffer (concentration of actin is $0.25 \mathrm{mg} / \mathrm{mL}$ ). Solution was mixed by pipetting up and down and placed on ice for one hour (in order to depolymerize actin oligomers). If several aliquots of actin were used, they were transferred to a common vial after diluting.

3. G-actin stock solution was centrifuged at $4{ }^{\circ} \mathrm{C}$ and $14000 \mathrm{rpm} / \mathrm{min}$ for 30 minutes.

4. The supernatant was transferred to a new vial and kept on ice. (pyrene-G-actin solution) 


\section{Sample preparation:}

1. An $1.0 \mathrm{mM}$ stock solution of optojasp-1 was prepared in DMSO, similar for jasplakinolide (positive control) and the corresponding Azo-1 (internal reference) $\operatorname{MainStock}(\mathrm{s})$.

2. DMSO primary stock was made by pipetting of DMSO to G-buffer in ratio 2:15. This can be also used to dilute the concentrations of the PrimaryStocks for concentration series. DMSO-PS.

3. MainStock of the jasplakinolide is diluted with $\mathrm{G}$ buffer to obtain $118 \mu \mathrm{M}$ solution (primary stock). (20 $\mu \mathrm{L}$ of the MainStock was dissolved in $150 \mu \mathrm{L}$ G buffer) jasplakinolide-PS.

4. MainStock of the optojasp-1 was diluted with $\mathrm{G}$ buffer to obtain $118 \mu \mathrm{M}$ solution (primary stock). (20 $\mu \mathrm{L}$ of the MainStock was dissolved in $150 \mu \mathrm{L} \mathrm{G}$ buffer) - optojasp-1-PS.

5. The main stock of the azo-1 reference was dilited with $\mathrm{G}$ buffer to a $118 \mu \mathrm{M}$ solution (primary stock). ( $20 \mu \mathrm{L}$ of the MainStock was dissolved in $150 \mu \mathrm{L}$ G buffer) - azo-1-PS.

5. When analyzing $(E) /(Z)$-isomers, the primary stock was split into two vials. One half was stored in the dark (E-optojasp-1 and $E$-azo-1), the other half was irradiated at $380 \mathrm{~nm}$ for $30 \mathrm{~s}$ shortly before compound addition (Z-optojasp-1 and Z-azo-1).

Carrying out the assay:

All experiments were carried out as duplicate determinations. A blank value and a reference value for jasplakinolide (positive control and for referencing) were recorded for each optojasp-1 isomer.

12 wells were used for the polymerization assay for optojasp-1:

Well $1+2$ : pyrene-G-actin + E-azo-1-PS ("E baseline reference")

Well 3 + 4: pyrene-G-actin + Z-azo-1-PS ("Z baseline reference")

Well 5 + 6: pyrene-G-actin + E-azo-1-PS + jasplakinolide-PS ("E positive control / Ref.)

Well 7 + 8: pyrene-G-actin + Z-azo-1-PS + jasplakinolide-PS ("Z positive control / Ref.)

Well 9 + 10: pyrene-G-actin + E-optojasp-1-PS

Well $11+12$ : pyrene-G-actin + Z-optojasp-1-PS 
$50 \mu \mathrm{L}$ pyrene $\mathrm{G}$ actin solution was pipetted into each well (1-12). In order to keep final concentrations and dilutions constant, $10 \mu \mathrm{L}$ of DMSO-PS was added to wells 1 - 4 and wells 9 - 12. In well $1+2$ and $5+6,10 \mu \mathrm{L}$ of $E$-azo-1-PS was added and in Well $3+4$ and $7+8$ $10 \mu \mathrm{L} Z$-azo-1-PS. $10 \mu \mathrm{L}$ of jasplakinolide-PS was pipetted into wells $5-8,10 \mu \mathrm{L}$ from $E$ optojasp-1-PS into wells $9+10$ and $10 \mu \mathrm{L}$ of Z-optojasp-1-PS into wells $11+12$.

The 384 well plate prepared in this way was placed in a plate reader (Tecan Infinite 200 PRO) and the measurement was initiated after $10 \mathrm{~min}$.

Plate reader measurement parameters:

Measurement type: $\quad$ Kinetic

Fluorescence reading from: Top-Mode

Fluorescence wavelengths: Excitation

Emission

Temperature:

Gain:

Number of Flashes:

Integration Time:

Lag Time:

Settle Time:

Mirror:

Shaking:
$37{ }^{\circ} \mathrm{C}$

50

3

$40 \mu \mathrm{s}$

$0 \mu \mathrm{s}$

$0 \mathrm{~ms}$ 50\% Mirror $5 \mathrm{~s}$ (orbital)
120 cycles, 60 s interval time

$350 \mathrm{~nm} \pm 20 \mathrm{~nm}$

$410 \mathrm{~nm} \pm 20 \mathrm{~nm}$

To evaluate the data, the values of the double determinations were averaged. The intensity of emitted enhanced fluorescence of the reference wells was subtracted from the intensity of emitted fluorescence of tested compounds. The slope $\mathrm{k}$ was determined from the data obtained in the range of the first 60 minutes. For this purpose, a linear regression according to $\mathrm{y}=\mathrm{kx}+\mathrm{c}(\mathrm{c}=0)$ was carried out by using Origin(Pro), Version 2019b (OriginLab Corporation, Northampton, MA, USA). 


\section{Supplementary Note 1: Chemical Synthesis and Characterisation}

Synthesis of Azoswitch Azo-1 (16):
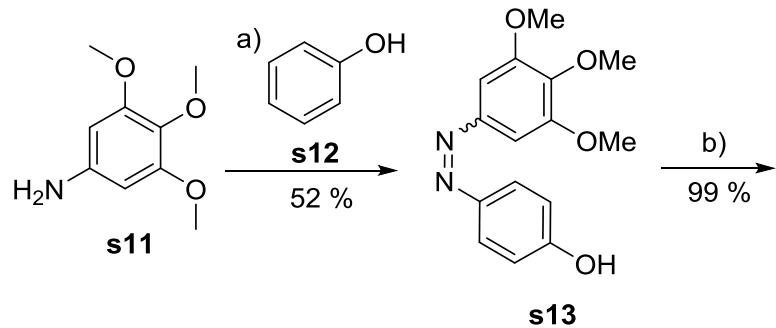
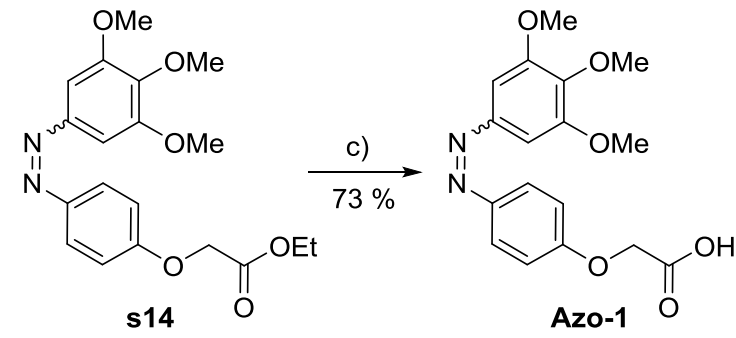

Conditions: a) 1. Amyl nitrite, $\mathrm{HCl}^{*} \mathrm{aq}, \mathrm{MeOH}, 0^{\circ} \mathrm{C} 2 . \mathrm{NaOH}^{*}$ aq, $\mathrm{MeOH}$, phenol, $0^{\circ} \mathrm{C}$. b) Ethyl bromoacetate, $\mathrm{K}_{2} \mathrm{CO}_{3}, \mathrm{Me}_{2} \mathrm{CO}$, rfx. c) $1 . \mathrm{NaOH}^{*} \mathrm{aq}, \mathrm{EtOH} / \mathrm{H}_{2} \mathrm{O}, \mathrm{rfx} 2$ 2. $\mathrm{HCl}^{*}$ aq

Azobenzene s13 was prepared according to literature procedure. ${ }^{\mathrm{S} 1, \mathrm{~S} 11}$

\section{Ethyl 2-(4-((3,4,5-trimethoxyphenyl)diazenyl)phenoxy)acetate (s14):}

To a solution of Azobenzene $\mathbf{s 1 3}\left(123 \mathrm{mg}, 0.428 \mathrm{mmol}, 1.0\right.$ equiv.) and $\mathrm{K}_{2} \mathrm{CO}_{3}$ (239 mg, 1.73 mmol, 4.0 equiv.) in Acetone (10 mL) Ethyl bromoacetate ( $155 \mu \mathrm{L}, 1.39 \mathrm{mmol}, 3.3$ equiv.) was added and stirred at $80{ }^{\circ} \mathrm{C}$ for $18 \mathrm{~h}$. The reaction mixture was concentrated under reduced pressure. The residue was dissolved in EtOAc $(15 \mathrm{~mL})$ and washed with phosphate buffer $(\mathrm{pH}$ $=7$ ). The organic layer was separated followed by extraction of the aqueous layer with EtOAc (3 x $10 \mathrm{~mL})$. The combined organic layers were dried $\left(\mathrm{Na}_{2} \mathrm{SO}_{4}\right)$, concentrated under reduced pressure and purified by silica-gel chromatography (EtOAc/petroleum ether, 1:4) to provide Azobenzene $\mathbf{s 1 4}(159 \mathrm{mg}, 99 \%)$ as a red oil. $\mathrm{R}_{\mathrm{f}}=0.18$ (EtOAc/petroleum ether, 1:4); ${ }^{1} \mathrm{H}-$ NMR: (400 MHz, $\left.\mathrm{CDCl}_{3}\right): \delta=7.90(\mathrm{~d}, J=8.5 \mathrm{~Hz}, 2 \mathrm{H}), 7.22(\mathrm{~s}, 2 \mathrm{H}), 7.03(\mathrm{~d}, J=8.5 \mathrm{~Hz}, 2 \mathrm{H})$, $4.71(\mathrm{~s}, 2 \mathrm{H}), 4.30(\mathrm{q}, J=7.4 \mathrm{~Hz}, 2 \mathrm{H}), 3.96(\mathrm{~s}, 6 \mathrm{H}), 3.93(\mathrm{~s}, 3 \mathrm{H}), 1.31(\mathrm{t}, J=7.6 \mathrm{~Hz}, 3 \mathrm{H})$.; ${ }^{13} \mathrm{C}-$ NMR: $\left(100 \mathrm{MHz} ; \mathrm{CDCl}_{3}\right): \delta=168.5,160.0,153.5,148.6,147.5,140.3,124.6,114.9,100.2$, 65.5, 61.6, 61.0, 56.2, 14.2; HPLC: $(\mathrm{C} 18$ Gravity, method $A) \mathrm{t}_{\mathrm{R}},(Z)=11.79 \mathrm{~min}, \mathrm{t}_{\mathrm{R}},(E)=$ 13.33 min; HRMS (ESI): m/Zcalcd for $\mathrm{C}_{19} \mathrm{H}_{23} \mathrm{~N}_{2} \mathrm{O}_{6}[\mathrm{M}+\mathrm{H}]^{+}: 375.1551$, found: 375.1553 .

\section{2-(4-((3,4,5-trimethoxyphenyl)diazenyl)phenoxy)acetic acid (Azo-1):}

Azobenzene $\mathbf{s 1 4}(139 \mathrm{mg}, 0.371 \mathrm{mmol}, 1.0$ equiv.) was dissolved in Methanol $(6.0 \mathrm{~mL})$, treated with aqueous $\mathrm{NaOH}(1.0 \mathrm{~mL}, 1 \mathrm{M})$ and stirred for $2 \mathrm{~h}$ at room temperature. The 
mixture was diluted with water $(7 \mathrm{~mL})$ before Methanol was removed under reduced pressure. The residue was extracted with EtOAc $(5 \times 5 \mathrm{~mL})$. The combined organic layers were dried $\left(\mathrm{Na}_{2} \mathrm{SO}_{4}\right)$ and concentrated under reduced pressure. If necessary the residue was purified by silica-gel chromatography (EtOAc/petroleum ether, 3:7 $+0.5 \%$ formic acid) to provide Azobenzen Azo-1 (94.1 mg, 73\%) as an orange solid. $\mathrm{R}_{\mathrm{f}}=0.22$ (EtOAc/petroleum ether, 3:7 $+0.5 \%$ formic acid); ${ }^{1} \mathrm{H}-\mathrm{NMR}:\left(300 \mathrm{MHz}, \mathrm{CDCl}_{3}\right): \delta=7.93(\mathrm{~d}, J=9.0 \mathrm{~Hz}, 2 \mathrm{H}), 7.23(\mathrm{~s}, 2 \mathrm{H})$, $7.06(\mathrm{~d}, J=9.0 \mathrm{~Hz}, 2 \mathrm{H}), 4.80$ (s, 2H), 3.98 (s, 6H), 3.94 (s, 3H).; ${ }^{13} \mathrm{C}-\mathrm{NMR}$ : (100 MHz; $\left.\mathrm{CDCl}_{3}\right): \delta=172.7,159.5,153.5,148.5,147.7,140.4,124.7,115.0,100.2,64.8,61.1,56.2$; HPLC: (C18 Gravity, method $A) \mathrm{t}_{\mathrm{R}},(Z)=10.10 \mathrm{~min}, \mathrm{t}_{\mathrm{R}},(E)=11.49 \mathrm{~min} ;$ HRMS (ESI): $\mathrm{m} / \mathrm{Z}$ calcd for $\mathrm{C}_{17} \mathrm{H}_{19} \mathrm{~N}_{2} \mathrm{O}_{6}[\mathrm{M}+\mathrm{H}]^{+}$: 347.1238, found: 347.1232 .

\section{Synthesis of Azoswitch Azo-2 (17):}

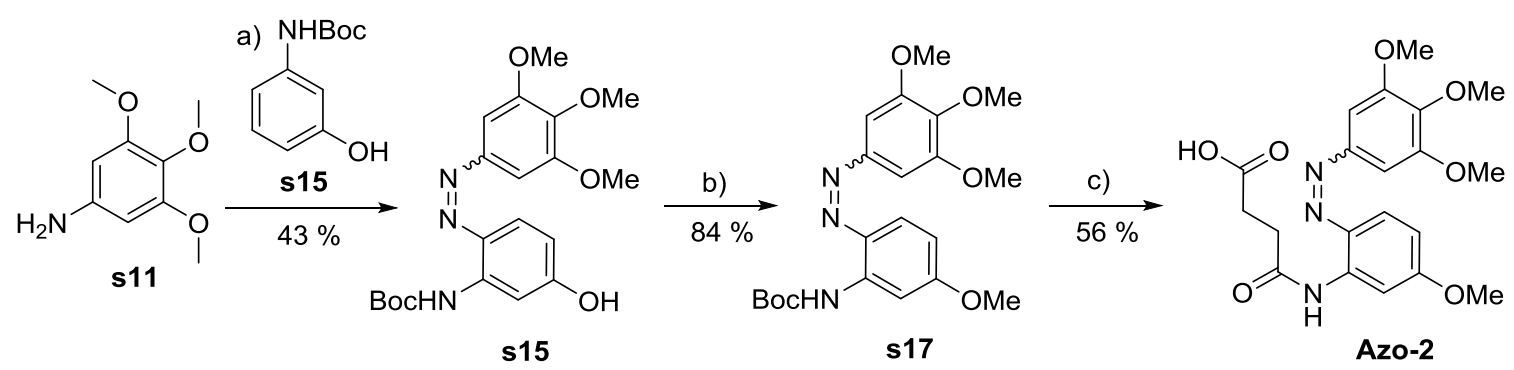

Conditions: a) 1 . Amyl nitrite, $\mathrm{HCl}^{*} \mathrm{aq}, \mathrm{MeOH}, 0^{\circ} \mathrm{C} 2 . \mathrm{NaOH}^{*}$ aq, $\mathrm{MeOH}, \mathbf{s} 15,0^{\circ} \mathrm{C}$. b) $\mathrm{Mel}, \mathrm{K}_{2} \mathrm{CO}_{3}, \mathrm{Me}_{2} \mathrm{CO}, \mathrm{RT}$. c) $1.4 \mathrm{M} \mathrm{HCl}$ in dioxane, $\mathrm{MeOH}$ 2. succinic anhydride, $\mathrm{K}_{2} \mathrm{CO}_{3}, \mathrm{DMF}, 70^{\circ} \mathrm{C}$.

Azobenzene s17 was prepared according to a literature procedure. ${ }^{\mathrm{S} 12}$

\section{4-((5-methoxy-2-((3,4,5-trimethoxyphenyl)diazenyl)phenyl)amino $)-4-o x o b u t a n o i c \quad$ acid} (Azo-2):

A solution of Azobenzene $\mathbf{s 1 7}$ (218 mg, $0.522 \mathrm{mmol}, 1.0$ equiv.) in a mixture of dioxane and Methanol (1:1, $4 \mathrm{~mL})$ was treated with $\mathrm{HCl}(2.0 \mathrm{~mL}, 4 \mathrm{M}$ in dioxane) and stirred at room temperature for $4 \mathrm{~h}$. After evaporation of all solvents, $\mathrm{K}_{2} \mathrm{CO}_{3}(788 \mathrm{mg}, 5.80 \mathrm{mmol}, 11.2$ equiv.) and succinic anhydride (234 mg, $2.34 \mathrm{mmol}, 4.5$ equiv.) were added and suspended in DMF $(4.0 \mathrm{~mL})$. The resulting mixture was stirred for $16 \mathrm{~h}$ at $65{ }^{\circ} \mathrm{C}$. After addition of water $(30 \mathrm{~mL})$ and EtOAc $(20 \mathrm{~mL})$ the $\mathrm{pH}$ was adjusted with sat. $\mathrm{NaHCO}_{3}$ to 11 . The organic layer was separated, the $\mathrm{pH}$ of the aqueous phase was adjusted to 4 with $\mathrm{HCl}(1 \mathrm{M})$, and extracted with EtOAc $(3 \times 50 \mathrm{~mL})$. The combined organic layers were dried $\left(\mathrm{Na}_{2} \mathrm{SO}_{4}\right)$ and concentrated 
under reduced pressure. If necessary the residue was purified by silica-gel chromatography (EtOAc/petroleum ether, 3:7 + 0.5\% formic acid) to provide azobenzene Azo-2 (122 mg, $56 \%)$ as an orange solid. $\mathrm{R}_{\mathrm{f}}=0.19$ (EtOAc/petroleum ether, $3: 7+0.5 \%$ formic acid); ${ }^{1} \mathrm{H}-$ NMR: (400 MHz, $\left.\mathrm{CDCl}_{3}\right): \delta=10.75(\mathrm{~s}, 1 \mathrm{H}), 8.29$ (d, $\left.J=2.3 \mathrm{~Hz}, 1 \mathrm{H}\right), 7.82(\mathrm{~d}, J=9.1 \mathrm{~Hz}$, $1 \mathrm{H}), 7.13(\mathrm{~s}, 2 \mathrm{H}), 6.73(\mathrm{dd}, J=9.1,2.6 \mathrm{~Hz}, 1 \mathrm{H}), 3.96(\mathrm{~s}, 6 \mathrm{H}), 3.94(\mathrm{~s}, 3 \mathrm{H}), 3.91$ (s, 3H), 2.87$2.82(\mathrm{~m}, 2 \mathrm{H}), 2.81-2.76(\mathrm{~m}, 2 \mathrm{H}) ;{ }^{13} \mathrm{C}-\mathrm{NMR}:\left(100 \mathrm{MHz} ; \mathrm{CDCl}_{3}\right): \delta=176.6,170.1,163.3$, $153.7,148.3,140.4,136.8,133.3,124.5,111.1,103.7,99.9,61.1,56.3,55.8,32.5,29.0$; HPLC: $($ C18 Gravity, method $A) \mathrm{t}_{\mathrm{R}},(E)=11.88 \mathrm{~min}$; HRMS $(\mathrm{ESI}): \mathrm{m} / \mathrm{Z}$ calcd for $\mathrm{C}_{20} \mathrm{H}_{24} \mathrm{~N}_{3} \mathrm{O}_{7}$ $[\mathrm{M}+\mathrm{H}]^{+}:$418.1609, found: 418.1617 .

\section{Synthesis of Optojasp 1-8:}

\section{$L$-Pea-L-Dap(Boc)-D-NMe-Trp- $\beta$ Tyr(OTIPS)-OH (7a):}<smiles>C=C(C)C[C@H](C)C(=O)N[C@H](CNC(=O)OCc1ccccc1)C(=O)N1c2cccc3[nH]cc(c23)C[C@H]1C(=O)NC(CC(=O)O)c1ccc(OC(F)(F)F)cc1</smiles>

A fritted $10 \mathrm{~mL}$-syringe was charged with polystyrene-bound 2-chlorotrityl chloride (100-200 mesh; $0.62 \mathrm{~g} ; 0.62 \mathrm{mmol}, 1.0$ equiv.). The resin was washed with $\mathrm{CH}_{2} \mathrm{Cl}_{2}$ and swollen for 15 min in DMF. A solution of $N$-Fmoc-protected $\beta$-Tyrosine 1 ( $0.35 \mathrm{~g}, 0.62 \mathrm{mmol}, 1.0$ equiv.) and $N, N$-diisopropylethylamine ( $0.53 \mathrm{~mL}, 3.1 \mathrm{mmol}, 5.0$ equiv.) in $\mathrm{DMF} / \mathrm{CH}_{2} \mathrm{Cl}_{2}(1: 1,5 \mathrm{~mL})$ was added in one portion at room temperature via needle, and the suspension was shaken (40 $\mathrm{rpm})$ at room temperature for $4 \mathrm{~h}$. The resin was drained and washed with $\mathrm{CH}_{2} \mathrm{Cl}_{2} / \mathrm{MeOH} / \mathrm{DIPEA}(17: 2: 1 ; 3 \times 5 \mathrm{~mL}), \mathrm{CH}_{2} \mathrm{Cl}_{2}(3 \times 5 \mathrm{~mL})$, DMF $(3 \times 10 \mathrm{~mL})$, and $\mathrm{MeOH}$ $(3 \times 5 \mathrm{~mL})$. The resin was dried under reduced pressure for $14 \mathrm{~h}$. The amino acid loading was determined to be $0.32 \mathrm{mmol} \cdot \mathrm{g}-1$ by Fmoc-deprotection of a small resin sample $(2 \mathrm{x} 7 \mathrm{mg})$ using piperidine/DMF $(1: 5 v / v)$ and subsequent measuring of the UV-absorption $(\lambda=301 \mathrm{~nm})$ against a blank sample.

The resin (1.0 g, $0.20 \mathrm{mmol})$ was swollen for 15 Minutes in DMF and deprotected by washing with piperidine/DMF $(1: 5 v / v ; 6 \mathrm{~mL} ; 1 \times 5 \mathrm{~min}+1 \times 15 \mathrm{~min})$ and DMF $(5 \mathrm{~mL})$. Fmoc- $D-$ tryptophan 11 (104.9 mg, $0.238 \mathrm{mmol}, 1.2$ equiv.), HATU (90.5 mg, $0.238 \mathrm{mmol}, 1.2$ equiv.), 
HOAt (32.4 mg, $0.238 \mathrm{mmol}, 1.2$ equiv.) and DIPEA ( $81.5 \mu 1,0.476 \mathrm{mmol}, 2.4$ equiv.) were successively dissolved in $\mathrm{DMF} / \mathrm{CH}_{2} \mathrm{Cl}_{2}(1: 1,5 \mathrm{~mL})$, shaken for $1 \mathrm{~min}$, and then added via needle to the resin at room temperature. The suspension was shaken (40 rpm) for $4 \mathrm{~h}$, washed with DMF (4 x $5 \mathrm{~mL})$ and dried.

The resin was swollen for 15 Minutes in DMF and deprotected by washing it with piperidine/DMF $(1: 5 \mathrm{v} / v ; 6 \mathrm{~mL} ; 1 \times 5 \mathrm{~min}+1 \times 15 \mathrm{~min})$ and DMF $(5 \mathrm{~mL})$. Fmoc- $L-$ diaminopropionic acid 12a (338.1 mg, $0.794 \mathrm{mmol}, 4.0$ equiv.), HATU (301.8 mg, $0.794 \mathrm{mmol}, 4.0$ equiv.), HOAt (108.0 mg, $0.794 \mathrm{mmol}, 4.0$ equiv.) and DIPEA (271.7 $\mu \mathrm{l}$, $1.587 \mathrm{mmol}, 8.0$ equiv.) were successively dissolved in $\mathrm{DMF} / \mathrm{CH}_{2} \mathrm{Cl}_{2}(1: 1,5 \mathrm{~mL})$, shaken for $1 \mathrm{~min}$, and then added via needle to the resin at room temperature. The suspension was shaken (40 rpm) for $14 \mathrm{~h}$, washed with $\mathrm{DMF}(4 \times 5 \mathrm{~mL})$ and dried. The resin was subjected to deprotection and subsequent coupling with pentenoic acid 13 (30.5 mg, $0.238 \mathrm{mmol}$, 1.2 equiv.) using the procedure described previously for the coupling of tryptophan $\mathbf{1 1 .}$

For cleavage, the resin was suspended in $\mathrm{CH}_{2} \mathrm{Cl}_{2} / \mathrm{HFIP}(2: 1 v / v, 6 \mathrm{~mL}, 1 \times 10 \mathrm{~min}$, $2 \times 15 \mathrm{~min})$. The combined filtrates were concentrated under reduced pressure and purified by silica-gel chromatography (20:1) to provide peptide acid 7a $(136 \mathrm{mg}, 82 \%$ based on the loading of the first amino acid) as colorless solid. $\mathrm{R}_{\mathrm{f}}=0.25\left(\mathrm{CH}_{2} \mathrm{Cl}_{2} / \mathrm{MeOH}, 20: 1\right) ;[\alpha]_{D}^{25.0}=$ $+15.3\left(c=0.95\right.$ in $\left.\mathrm{CHCl}_{3}\right) ;{ }^{1} \mathrm{H}-\mathrm{NMR}:\left(400 \mathrm{MHz}, \mathrm{CDCl}_{3}\right): \delta=8.73$ (br, $\left.1 \mathrm{H}\right), 7.57$ (d, $J=7.6 \mathrm{~Hz}, 1 \mathrm{H}), 7.30(\mathrm{~d}, J=7.8 \mathrm{~Hz}, 1 \mathrm{H}), 7.27-7.01(\mathrm{~m}, 6 \mathrm{H}), 6.93-6.89(\mathrm{~m}, 1 \mathrm{H}), 6.76(\mathrm{~d}$, $J=8.1 \mathrm{~Hz}, 3 \mathrm{H}), 5.55(\mathrm{~s}, 1 \mathrm{H}), 5.42(\mathrm{~s}, 1 \mathrm{H}), 4.72(\mathrm{~d}, J=10.9 \mathrm{~Hz}, 1 \mathrm{H}), 4.68-4.55(\mathrm{~m}, 2 \mathrm{H})$, 3.48-3.16 (m, 2H), 3.09-2.73 (m, 4H), 2.92 (s, 3H), 2.45-2.26 (m, 2H), 2.02-1.94 (m, 1H), $1.66(\mathrm{~s}, 3 \mathrm{H}), 1.45-1.39(\mathrm{~m}, 9 \mathrm{H}), 1.26(\mathrm{~s}, 3 \mathrm{H}), 1.11-1.06(\mathrm{~m}, 21 \mathrm{H})$; IR: $\widetilde{v}_{\max }=3302,2931$, 2862, 1643, 1512, 1265; HPLC: $t_{R}=15.17$ min (C18 Gravity, method B); HRMS (ESI): m/Z calcd for $\mathrm{C}_{45} \mathrm{H}_{68} \mathrm{~N}_{5} \mathrm{O}_{8} \mathrm{Si}[\mathrm{M}+\mathrm{H}]^{+}:$834.4832, found: 834.4855.

\section{$L-P e a-L-D a b(B o c)-D-N M e-T r p-\beta T y r(O T I P S)-O H(7 b):$}<smiles>C=C(C)C[C@H](C)C(=O)N[C@@H](CCNC(=O)OCc1ccccc1)C(=O)N1c2cccc3[nH]cc(c23)C[C@H]1C(=O)N[C@@H](CC(=O)O)c1ccc(O[SnH3])cc1</smiles> 
According to the procedure described for the synthesis of compound $\mathbf{7 a}$ peptide acid $\mathbf{7 b}$ (137 mg, 65\% based on the loading of the first amino acid) was obtained by replacing Fmoc$L$-diaminopropionic acid 12a with Fmoc- $L$-diaminobutyric acid 12b. $\mathrm{R}_{\mathrm{f}}=0.26$ $\left(\mathrm{CH}_{2} \mathrm{Cl}_{2} / \mathrm{MeOH}, 20: 1\right) ;[\alpha]_{D}^{22.9}=+30.3\left(c=0.99\right.$ in $\left.\mathrm{CHCl}_{3}\right) ;{ }^{1} \mathrm{H}-\mathrm{NMR}:\left(250 \mathrm{MHz}, \mathrm{CDCl}_{3}\right): \delta$ $=8.48(\mathrm{br}, 1 \mathrm{H}), 7.53(\mathrm{~d}, J=7.3 \mathrm{~Hz}, 1 \mathrm{H}), 7.29(\mathrm{~m}, J=7.2 \mathrm{~Hz}, 1 \mathrm{H}), 7.19-6.89$ (m, 7H), 6.77 (d, $J=7.7 \mathrm{~Hz}, 2 \mathrm{H}), 6.78-6.72(\mathrm{~m}, 1 \mathrm{H}), 5.50-5.32(\mathrm{~m}, 2 \mathrm{H}), 4.93$ (br s, 1H), 4.73 (s, 1H), 4.67 (s, 1H), 3.49-3.19 (m, 2H), 3.08-2.70 (m, 4H), 2.88 (s, 3H), 2.60-2.28 (m, 4H), 2.02 (dd, $J=13.2,7.7 \mathrm{~Hz}, 1 \mathrm{H}), 1.65(\mathrm{~s}, 3 \mathrm{H}), 1.41(\mathrm{~s}, 9 \mathrm{H}), 1.27(\mathrm{~d}, J=6.6 \mathrm{~Hz}, 3 \mathrm{H}), 1.09$ (d, 21H, $J=6.5 \mathrm{~Hz}$ ); IR: $\tilde{v}_{\max }=3309,2927,2866,1643,1508,1265 ;$ HPLC: $t_{R}=15.15 \mathrm{~min}(\mathrm{C} 18$ Gravity, method B); HRMS (ESI): $\mathrm{m} / \mathrm{Z}$ calcd for $\mathrm{C}_{46} \mathrm{H}_{70} \mathrm{~N}_{5} \mathrm{O}_{8} \mathrm{Si}[\mathrm{M}+\mathrm{H}]^{+}$: 848.4989, found: 848.4993.

\section{$L$-Pea-L-Orn(Boc)-D-NMe-Trp- $\beta$ Tyr(OTIPS)-OH (7c):}<smiles>C=C(C)C[C@H](C)C(=O)N[C@@H](CCCNC(=O)OCc1ccccc1)C(=O)N1c2cccc3[nH]cc(c23)C[C@H]1C(=O)NC(CC(=O)O)c1ccc(OC(C)(C)C)cc1</smiles>

According to the procedure described for the synthesis of compound $\mathbf{7 a}$ peptide acid $\mathbf{7 c}$ (160 mg, 72\% based on the loading of the first amino acid) was obtained by replacing Fmoc$D$-diaminopropionic acid 12a with Fmoc- $D$-ornithine 12c. $\mathrm{R}_{\mathrm{f}}=0.26\left(\mathrm{CH}_{2} \mathrm{Cl}_{2} / \mathrm{MeOH}, 20: 1\right)$; $[\alpha]_{D}^{22.9}=+22.5\left(c=0.99\right.$ in $\left.\mathrm{CHCl}_{3}\right) ;{ }^{1} \mathrm{H}-\mathrm{NMR}:\left(300 \mathrm{MHz}, \mathrm{CDCl}_{3}\right): \delta=8.84(\mathrm{br}, 1 \mathrm{H}), 7.58(\mathrm{~d}$, $J=7.6 \mathrm{~Hz}, 1 \mathrm{H}), 7.36(\mathrm{~d}, J=7.1 \mathrm{~Hz}, 1 \mathrm{H}), 7.20-712(\mathrm{~m}, 4 \mathrm{H}), 7.10-7.02(\mathrm{~m}, 2 \mathrm{H}), 6.95(\mathrm{~s}, 1 \mathrm{H})$, $6.81(\mathrm{~d}, 2 \mathrm{H}), 6.65(\mathrm{~s}, 1 \mathrm{H}), 5.66(\mathrm{~s}, 1 \mathrm{H}), 5.42(\mathrm{q}, J=7.4 \mathrm{~Hz}, 1 \mathrm{H}), 4.75(\mathrm{~s}, 1 \mathrm{H}), 4.69(\mathrm{~s}, 1 \mathrm{H})$, 4.63-4.56 (m, 1H), 3.40-3.28 (m, 2H), 2.91 (s, 3H), 2.87-2.82 (m, 2H), 2.81-2.70 (m, 2H), 2.52-2.46 (m, 1H), 2.37-2.29 (m, 1H), $2.02(\mathrm{q}, J=6.6 \mathrm{~Hz}, 1 \mathrm{H}), 1.66(\mathrm{~s}, 3 \mathrm{H}), 1.47(\mathrm{~s}, 9 \mathrm{H})$, 1.45-1.40 (m, 2H), $1.27(\mathrm{~d}, J=6.3 \mathrm{~Hz}, 3 \mathrm{H}), 1.09(\mathrm{~d}, 21 \mathrm{H}), 0.89-0.83(\mathrm{~m}, 2 \mathrm{H})$; IR: $\tilde{v}_{\max }=$ 3309, 2927, 2866, 1643, 1508, 1265; HPLC: $t_{R}=15.15$ min (C18 Gravity, method B); HRMS (ESI): $\mathrm{m} / \mathrm{Z}$ calcd for $\mathrm{C}_{47} \mathrm{H}_{72} \mathrm{~N}_{5} \mathrm{O}_{8} \mathrm{Si}[\mathrm{M}+\mathrm{H}]^{+}:$862.5145, found: $862.5160, \mathrm{~m} / \mathrm{Z}$ calcd for $\mathrm{C}_{47} \mathrm{H}_{71} \mathrm{~N}_{5} \mathrm{O}_{8} \mathrm{SiNa}[\mathrm{M}+\mathrm{Na}]^{+}$: 884.4964, found: 884.4968. 


\section{$L$-Pea-L-Dap(Boc)-D-NMe-Trp- $\beta$ Tyr(OTIPS)-O-2-(S)-hexene (8a):}

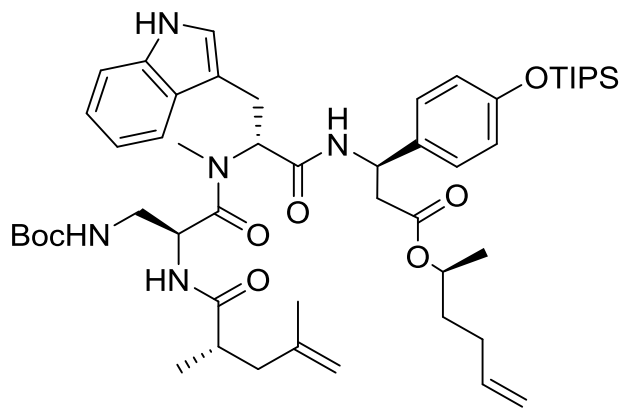

(S)-5-Hexen-2-ol (5) $(17.4 \mu 1,143.4 \mu \mathrm{mol}, 4.0$ equiv.) was added to a solution of peptide acid 7a (30 mg, $35.9 \mu \mathrm{mol}, \quad 1.0$ equiv), 4-(dimethylamino)pyridine $\quad(17.5 \mathrm{mg}, 143.4 \mu \mathrm{mol}$, 4.0 equiv.), $\quad N, N$-diisopropylethylamine $\quad(12.2 \mu \mathrm{L}, \quad 71.7 \mu \mathrm{mol}, \quad 2.0$ equiv.) and $N$-(3dimethylaminopropyl)- $N$ '-ethylcarbodiimide hydrochloride (13.7 mg, $71.7 \mu \mathrm{mol}, 2.0$ equiv.) in $\mathrm{CH}_{2} \mathrm{Cl}_{2}(2.0 \mathrm{~mL})$ under an atmosphere of argon. After addition of DMF $(200 \mu \mathrm{L})$ the mixture was stirred at room temperature for $16 \mathrm{~h}$. The reaction was quenched by addition of saturated aqueous $\mathrm{NH}_{4} \mathrm{Cl}$-solution $(3 \mathrm{~mL})$ and EtOAc $(2.0 \mathrm{~mL})$. After separation the aqueous layer was extracted with EtOAc $(2 \times 5 \mathrm{~mL})$. The combined organic layers were dried $\left(\mathrm{Na}_{2} \mathrm{SO}_{4}\right)$, concentrated under reduced pressure, and purified by silica-gel chromatography (2:1 EtOAc/cyclohexane) to provide diene $8 \mathbf{a}(27.0 \mathrm{mg}, 82 \%)$ as a pale yellow solid. $\mathrm{R}_{\mathrm{f}}=$ 0.30 (EtOAc/cyclohexan, 2:1); $[\alpha]_{D}^{25.5}=+21.9\left(c=1.0\right.$ in $\left.\mathrm{CHCl}_{3}\right) ;{ }^{1} \mathrm{H}-\mathrm{NMR}$ : $(400 \mathrm{MHz}$, $\mathrm{CDCl}_{3}$, rotamer mixture 1:1): $\delta=8.81(\mathrm{~d}, J=8.3 \mathrm{~Hz}, 1 \mathrm{H}), 8.14(\mathrm{~d}, J=4.8 \mathrm{~Hz}, 1 \mathrm{H}), 7.61(\mathrm{~d}$, $J=4.8 \mathrm{~Hz}, 1 \mathrm{H}), 7.46(\mathrm{~d}, J=7.3 \mathrm{~Hz}, 1 \mathrm{H}), 7.33(\mathrm{~d}, J=8.1 \mathrm{~Hz}, 1 \mathrm{H}), 7.25-7.05(\mathrm{~m}, 11 \mathrm{H}), 6.98$ (s, 1H), $6.91(\mathrm{~m}, 2 \mathrm{H}), 6.77(\mathrm{~d}, J=8.6 \mathrm{~Hz}, 4 \mathrm{H}), 6.31(\mathrm{~d}, J=5.6 \mathrm{~Hz}, 1 \mathrm{H}), 5.79-5.69(\mathrm{~m}, 2 \mathrm{H})$, $5.69(\mathrm{dd}, J=10.9,5.8 \mathrm{~Hz}, 1 \mathrm{H}), 5.53-5.47(\mathrm{~m}, 1 \mathrm{H}), 5.38$ (q, $J=7.1 \mathrm{~Hz}, 1 \mathrm{H}), 5.00-4.92$ (m, $5 \mathrm{H}), 4.89-4.81(\mathrm{~m}, 3 \mathrm{H}), 4.77(\mathrm{~d}, J=7.6 \mathrm{~Hz}, 2 \mathrm{H}), 4.68(\mathrm{~d}, J=5.6 \mathrm{~Hz}, 2 \mathrm{H}), 4.56(\mathrm{dd}, J=10.0$, $3.9 \mathrm{~Hz}, 2 \mathrm{H}), 4.43(\mathrm{t}, J=5.4 \mathrm{~Hz}, 1 \mathrm{H}), 3.66(\mathrm{dd}, J=15.3,4.2 \mathrm{~Hz}, 1 \mathrm{H}), 3.50(\mathrm{dd}, J=15.7$, $5.3 \mathrm{~Hz}, 1 \mathrm{H}), 3.25-3.16(\mathrm{~m}, 2 \mathrm{H}), 3.06$ (dd, $J=15.2,10.4 \mathrm{~Hz}, 2 \mathrm{H}), 2.96$ (s, 3H), 2.92 (s, 3H), 2.83-2.74 (m, 4H), 2.45-2.28 (m, 2H), 2.02-1.99 (m, 4H), 1.68 (s, 3H), 1.67 (s, 3H), $1.63-$ $1.47(\mathrm{~m}, 6 \mathrm{H}), 1.43(\mathrm{~s}, 9 \mathrm{H}), 1.42(\mathrm{~s}, 9 \mathrm{H}), 1.25-1.18(\mathrm{~m}, 14 \mathrm{H}), 1.09(\mathrm{dd}, J=7.2,2.7 \mathrm{~Hz}, 42 \mathrm{H})$; ${ }^{13} \mathrm{C}-\mathrm{NMR}:\left(100 \mathrm{MHz} ; \mathrm{CDCl}_{3}\right.$, rotamer mixture 1:1): $\delta=176.8,174.7,171.2,170.5,170.1$, $169.9,168.8,167.7,156.8,155.4,155.3,143.6,142.8,137.7,137.6,136.1,136.0,133.9$, $127.9,128.6,127.2,126.9,122.9,122.4,122.2$, 119.9, 119.8, 119.4, 118.1, 115.0, 114.9, 112.4, 112.1, 111.2, 111.1, 110.9, 80.5, 79.9, 77.2, 70.8, 70.7, 62.6, 60.4, 56.9, 49.9, 49.7, 49.5, 41.9, 41.7, 41.0, 40.8, 39.0, 38.6, 34.9, 34.8, 29.7, 29.5, 29.4, 28.3, 22.7, 22.2, 21.0, $19.8,19.8,19.717 .9,17.4,14.2,14.1,12.6$; IR: $\tilde{v}_{\max }=3302,3062,2924,2866,2360,2341$, 
1647, 1508, 1458, 1365, 1269, 1172; HPLC: $t_{R}=21.12$ min (C18 Gravity, method B); HRMS (ESI): $\mathrm{m} / \mathrm{Z}$ calcd for $\mathrm{C}_{51} \mathrm{H}_{78} \mathrm{~N}_{5} \mathrm{O}_{8} \mathrm{Si}[\mathrm{M}+\mathrm{H}]^{+}:$916.5614, found: 916.5629 .

\section{$L$-Pea-L-Dab(Boc)-D-NMe-Trp- $\beta$ Tyr(OTIPS)-O-2-(S)-hexene (8b):}

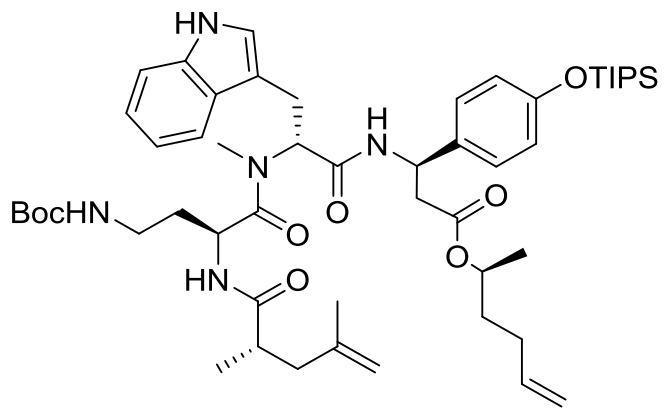

Peptide acid 7b (60 mg, $70.7 \mu \mathrm{mol}, 1.0$ equiv), was treated with $(S)-5$-Hexen-2-ol (5) (32.6 $\mu \mathrm{l}, \quad 269.6 \mu \mathrm{mol}, \quad 3.8$ equiv.), 4 -(dimethylamino)pyridine $\quad(33.0 \mathrm{mg}, \quad 270.0 \mu \mathrm{mol}$, 3.8 equiv.), $\quad N, N$-diisopropylethylamine $(23.0 \mu \mathrm{L}, 134.4 \mu \mathrm{mol}, 1.9$ equiv. $)$ and $N$-(3dimethylaminopropyl)- $N$ '-ethylcarbodiimide hydrochloride (26.0 mg, $135.6 \mu$ mol, 1.9 equiv.) in $\mathrm{CH}_{2} \mathrm{Cl}_{2}(2.0 \mathrm{~mL})$ according to the procedure described for the synthesis of compound $\mathbf{8 a}$, to provide diene $\mathbf{8 b}(37.0 \mathrm{mg}, 57 \%)$ as a pale yellow solid. $\mathrm{R}_{\mathrm{f}}=0.29$ (EtOAc/cyclohexan, 2:1); $[\alpha]_{D}^{24.1}=+16.1\left(c=1.0\right.$ in $\left.\mathrm{CHCl}_{3}\right) ;{ }^{1} \mathrm{H}-\mathrm{NMR}:\left(250 \mathrm{MHz}, \mathrm{CDCl}_{3}\right): \delta=8.34(\mathrm{br} \mathrm{s}, 1 \mathrm{H}), 7.60(\mathrm{~d}$, $J=7.8 \mathrm{~Hz}, 1 \mathrm{H}), 7.32(\mathrm{~d}, J=8.1 \mathrm{~Hz}, 1 \mathrm{H}), 7.17(\mathrm{t}, J=7.3 \mathrm{~Hz}, 1 \mathrm{H}), 7.12(\mathrm{t}, J=7.5 \mathrm{~Hz}, 1 \mathrm{H})$, 7.09-7.02 (m, 1H), $7.06(\mathrm{~d}, J=8.6 \mathrm{~Hz}, 2 \mathrm{H}), 6.95(\mathrm{~d}, J=1.8 \mathrm{~Hz}, 1 \mathrm{H}), 6.77(\mathrm{~d}, J=8.6 \mathrm{~Hz}$, $2 \mathrm{H}), 6.53(\mathrm{~d}, J=6.8 \mathrm{~Hz}, 1 \mathrm{H}), 5.76-5.66(\mathrm{~m}, 1 \mathrm{H}), 5.55(\mathrm{dd}, J=10.0,6.2 \mathrm{~Hz}, 1 \mathrm{H}), 5.35(\mathrm{dd}$, $J=6.8 \mathrm{~Hz}, 1 \mathrm{H}), 5.16($ br s, 1H) , 4.96-4.91 (m, 2H), 4.85-4.79 (m, 1H), $4.76(\mathrm{~s}, 1 \mathrm{H}), 4.69$ (s, $1 \mathrm{H}), 4.71-4.66(\mathrm{~m}, 1 \mathrm{H}), 3.52(\mathrm{dd}, J=15.4,6.1 \mathrm{~Hz}, 1 \mathrm{H}), 3.28(\mathrm{dd}, J=15.3,10.5 \mathrm{~Hz}, 1 \mathrm{H})$, 3.10-3.01 (m, 1H), $2.95(\mathrm{~s}, 3 \mathrm{H}), 2.86(\mathrm{dd}, J=15.2,6.8 \mathrm{~Hz}, 1 \mathrm{H}), 2.72(\mathrm{dd}, J=15.2,6.6 \mathrm{~Hz}$, $1 \mathrm{H}), 2.58-2.50(\mathrm{~m}, 1 \mathrm{H}), 2.48-2.42(\mathrm{~m}, 1 \mathrm{H}), 2.38-2.32(\mathrm{~m}, 1 \mathrm{H}), 2.11(\mathrm{dd}, J=14.1,7.6 \mathrm{~Hz}$, $1 \mathrm{H}), 1.98-1.86(\mathrm{~m}, 2 \mathrm{H}), 1.68(\mathrm{~s}, 3 \mathrm{H}), 1.52-1.45(\mathrm{~m}, 3 \mathrm{H}), 1.43(\mathrm{~s}, 9 \mathrm{H}), 1.29-1.19(\mathrm{~m}, 4 \mathrm{H})$, 1.12-1.10 (m, 3H), 1.09 (d, $J=7.1 \mathrm{~Hz}, 21 \mathrm{H})$; ${ }^{13} \mathrm{C}-\mathrm{NMR}:\left(62.5 \mathrm{MHz} ; \mathrm{CDCl}_{3}\right): \delta=176.8$, $173.0,170.5,168.9,156.1,155.5,142.8,137.6,136.3,132.7,127.5,127.2$, 122.6, 122.1, $119.8,119.5,118.7,114.9,112.4,111.2,110.9$, 79.2, 77.2, 70.8, 56.9, 49.4, 47.2, 41.8, 40.7, 39.0, 34.8, 32.4, 29.7, 29.4, 28.4, 23.6, 22.3, 19.8, 17.9, 17.6, 12.6; IR: $\tilde{v}_{\max }=3309,2927$, 2866, 1643, 1508, 1269, 1172, 771; HPLC: $t_{R}=21.01$ min (C18 Gravity, method B); HRMS (ESI): $\mathrm{m} / \mathrm{Z}$ calcd for $\mathrm{C}_{52} \mathrm{H}_{80} \mathrm{~N}_{5} \mathrm{O}_{8} \mathrm{Si}[\mathrm{M}+\mathrm{H}]^{+}:$930.5781, found: 930.5800 . 


\section{$L$-Pea-L-Orn(Boc)-D-NMe-Trp- $\beta$ Tyr(OTIPS)-O-2-(S)-hexene (8c):}<smiles>C=CCCC(C)OC(=O)CC(NC(=O)CCN(C(=O)C(CCCNC(C)(C)C)NC(=O)[C@H](C)CC(=C)O)c1cccc2[nH]ccc12)c1ccc(OC(C)(C)C)cc1</smiles>

Peptide acid 7c $(58.0 \mathrm{mg}, 65.0 \mu \mathrm{mol}, 1.0$ equiv), was treated with $(S)-5$-Hexen-2-ol (5) (31.0 $\mu \mathrm{l}, \quad 258.0 \mu \mathrm{mol}, \quad 4.0$ equiv.), 4-(dimethylamino)pyridine $\quad(32.0 \mathrm{mg}, \quad 258.0 \mu \mathrm{mol}$, 4.0 equiv.), $\quad N, N$-diisopropylethylamine $(23.0 \mu \mathrm{L}, \quad 129.0 \mu \mathrm{mol}, 2.0$ equiv.) and $N$-(3dimethylaminopropyl)- $N$ '-ethylcarbodiimide hydrochloride (25.0 mg, $129.0 \mu \mathrm{mol}, 2.0$ equiv.) in $\mathrm{CH}_{2} \mathrm{Cl}_{2}(1.2 \mathrm{~mL})$ according to the procedure described for the synthesis of compound $\mathbf{8 a}$, to provide diene $8 \mathbf{c}(49.0 \mathrm{mg}, 80 \%)$ as a pale yellow solid. $\mathrm{R}_{\mathrm{f}}=0.34$ (EtOAc/cyclohexan, 2:1); $[\alpha]_{D}^{24.1}=+13.5\left(c=1.0\right.$ in $\left.\mathrm{CHCl}_{3}\right) ;{ }^{1} \mathrm{H}-\mathrm{NMR}:\left(300 \mathrm{MHz}, \mathrm{CDCl}_{3}\right): \delta=9.01$ (br s, $\left.1 \mathrm{H}\right), 7.61(\mathrm{~d}$, $J=7.7 \mathrm{~Hz}, 1 \mathrm{H}), 7.37(\mathrm{~d}, J=7.8 \mathrm{~Hz}, 1 \mathrm{H}), 7.16(\mathrm{~d}, J=7.7 \mathrm{~Hz}, 1 \mathrm{H}), 7.20-7.08(\mathrm{~m}, 4 \mathrm{H}), 6.95$ (s, $1 \mathrm{H}), 6.80(\mathrm{~d}, J=8.6 \mathrm{~Hz}, 2 \mathrm{H}), 6.41(\mathrm{~d}, J=5.2 \mathrm{~Hz}, 1 \mathrm{H}), 5.79-5.67(\mathrm{~m}, 2 \mathrm{H}), 5.45-5.35(\mathrm{~m}, 1 \mathrm{H})$, 4.99-4.90 (m, 2H), 4.88-4.81 (m, 1H), $4.76(\mathrm{~s}, 1 \mathrm{H}), 4.69(\mathrm{~s}, 1 \mathrm{H}), 4.53(\mathrm{q}, J=6.1 \mathrm{~Hz}, 1 \mathrm{H})$, $4.44(\mathrm{t}, 1 \mathrm{H}, J=5.3 \mathrm{~Hz}), 3.46(\mathrm{dd}, J=15.0,4.7 \mathrm{~Hz}, 1 \mathrm{H}), 3.27(\mathrm{dd}, J=15.9,12.2 \mathrm{~Hz}, 1 \mathrm{H}), 2.94$ (s, 3H), 2.97-2.90 (m, 1H), $2.77(\mathrm{dd}, J=15.3,6.3 \mathrm{~Hz}, 1 \mathrm{H}), 2.79-2.68(\mathrm{~m}, 1 \mathrm{H}), 2.46-2.31(\mathrm{~m}$, 2H), 2.04-1.91 (m, 4H), $1.67(\mathrm{~s}, 3 \mathrm{H}), 1.52-1.41(\mathrm{~m}, 3 \mathrm{H}), 1.48(\mathrm{~s}, 9 \mathrm{H}), 1.29-1.20(\mathrm{~m}, 7 \mathrm{H})$, $1.09(\mathrm{~d}, J=6.9 \mathrm{~Hz}, 21 \mathrm{H}), 0.77-0.68(\mathrm{~m}, 2 \mathrm{H}) ;{ }^{13} \mathrm{C}-\mathrm{NMR}:\left(62.5 \mathrm{MHz} ; \mathrm{CDCl}_{3}\right): \delta=176.4$, 173.2 , 170.5, 169.0, 156.3, 155.4, 142.8, 137.7, 136.7, 133.0, 127.6, 127.4, 122.2, 121.9, 119.8, 119.3, 118.6, 114.8, 112.4, 111.2, 110.8, 79.6, 77.2, 70.7, 56.7, 53.4, 49.5, 49.4, 41.8, $40.9,38.7,34.9,29.7,29.4,28.5,23.2,22.7,22.2,19.8,17.9,17.2,12.6$; IR: $\tilde{v}_{\max }=3305$, 2924, 2866, 2360, 2341, 1643, 1265; HPLC: $t_{R}=21.31$ min (C18 Gravity, method B); HRMS (ESI): $\mathrm{m} / \mathrm{Z}$ calcd for $\mathrm{C}_{53} \mathrm{H}_{82} \mathrm{~N}_{5} \mathrm{O}_{8} \mathrm{Si}[\mathrm{M}+\mathrm{H}]^{+}: 944.5937$ found: 944.5944. 
cyclo-[(2S,4E,8S)Hdn-L-Dap(Boc)-D-NMe-Trp- $\beta$ Tyr(OTIPS)] (9a):<smiles>C/C1=C/CC[C@H](C)OC(=O)C[C@@H](c2ccc(OC(F)(F)F)cc2)NC(=O)[C@H](Cc2c[nH]c3ccccc23)C1=O</smiles>

Diene 8a (38.0 mg, $41.5 \mu \mathrm{mol}, 1.0$ equiv.) was dissolved in $\mathrm{CH}_{2} \mathrm{Cl}_{2}(38 \mathrm{~mL}, \mathrm{c}=1.1$ mmol-1-1) and heated to reflux for 20 min under an atmosphere of argon. After addition of a solution of $2^{\text {nd }}$ generation Grubbs catalyst ( $3.8 \mathrm{mg}, 4.47 \mu \mathrm{mol}, 0.11$ equiv., in $0.5 \mathrm{~mL} \mathrm{CH} \mathrm{Cl}_{2}$ ) the reaction mixture was stirred under reflux for additional $3 \mathrm{~h}$. After cooling, the solvent was removed under reduced pressure and purified by silica-gel chromatography (2:1 EtOAc/cyclohexane) to provide cyclopeptide $9 \mathbf{a}(27.0 \mathrm{mg}, 82 \%)$ as an off-white solid. $\mathbf{R}_{\mathrm{f}}=$ 0.21 (EtOAc/Cyclohexan, 2:1); $[\alpha]_{D}^{24.2}=+25.8\left(c=0.8\right.$ in $\left.\mathrm{CHCl}_{3}\right) ;{ }^{1} \mathrm{H}-\mathrm{NMR}:(400 \mathrm{MHz}$, $\left.\mathrm{CDCl}_{3}\right): \delta=1$ amino-hydrogen not observed, 8.19 (br s, $\left.1 \mathrm{H}\right), 7.64(\mathrm{~d}, J=7.8 \mathrm{~Hz}, 1 \mathrm{H})$, $7.35(\mathrm{~d}, J=7.8 \mathrm{~Hz}, 1 \mathrm{H}), 7.20(\mathrm{t}, J=7.6 \mathrm{~Hz}, 1 \mathrm{H}), 7.14$ (t, $J=7.8 \mathrm{~Hz}, 1 \mathrm{H}), 7.09$ (d, $J=8.6 \mathrm{~Hz}$, 1H), $7.05(\mathrm{~d}, J=8.3 \mathrm{~Hz}, 2 \mathrm{H}), 6.99(\mathrm{~s}, 1 \mathrm{H}), 6.80(\mathrm{~d}, J=8.3 \mathrm{~Hz}, 2 \mathrm{H}), 6.69$ (d, $J=5.1 \mathrm{~Hz}, 1 \mathrm{H})$, $5.68(\mathrm{dd}, J=8.8,7.3 \mathrm{~Hz}, 1 \mathrm{H}), 5.24(\mathrm{td}, J=7.7,3.8 \mathrm{~Hz}, 1 \mathrm{H}), 5.03(\mathrm{t}, J=6.7 \mathrm{~Hz}, 1 \mathrm{H}), 4.92-$ $4.88(\mathrm{~m}, 1 \mathrm{H}), 4.85-4.80(\mathrm{~m}, 1 \mathrm{H}), 3.42-3.36(\mathrm{~m}, 1 \mathrm{H}), 3.33-3.23(\mathrm{~m}, 2 \mathrm{H}), 2.97(\mathrm{~s}, 3 \mathrm{H}), 2.84-$ $2.77(\mathrm{~m}, 2 \mathrm{H}), 2.56(\mathrm{dd}, J=15.4,7.8 \mathrm{~Hz}, 1 \mathrm{H}), 2.49-2.41(\mathrm{~m}, 2 \mathrm{H}), 1.91(\mathrm{~d}, J=11.1 \mathrm{~Hz}, 1 \mathrm{H})$, 1.87-1.80 (m, 2H), 1.58-1.51 (m, 1H), $1.48(\mathrm{~s}, 3 \mathrm{H}), 1.43(\mathrm{~s}, 9 \mathrm{H}), 1.27-1.22(\mathrm{~m}, 4 \mathrm{H}), 1.17$ (m, $3 \mathrm{H}), 1.10(\mathrm{~d}, J=7.3 \mathrm{~Hz}, 21 \mathrm{H}) .{ }^{13} \mathrm{C}-\mathrm{NMR}:\left(100 \mathrm{MHz} ; \mathrm{CDCl}_{3}\right): \delta=175.6,171.8,170.4,168.8$, $155.8,155.4,136.2,133.9,132.8,127.1,127.0,124.7,122.4,122.3,119.9,119.5,118.6$, $111.3,110.9$, 79.3, 77.2, 69.6, 56.1, 50.2, 49.0, 43.4, 43.1, 39.8, 35.5 , 30.4, 28.4, 23.3, 23.0, 20.3, 20.0, 17.9, 16.2, 12.6. IR: $\tilde{v}_{\max }=3332,3305,2924,2866,1635,1508,1265,1172$; HPLC: $t_{R}=17.84$ min (C18 Gravity, method $B$ ); HRMS (ESI): m/Z calcd for $\mathrm{C}_{49} \mathrm{H}_{74} \mathrm{~N}_{5} \mathrm{O}_{8} \mathrm{Si}$ $[\mathrm{M}+\mathrm{H}]^{+}:$888.5301, found: 888.5313. 
cyclo-[(2S,4E,8S)Hdn-L-Dab(Boc)-D-NMe-Trp- $\beta \operatorname{Tyr}($ OTIPS)] (9b):

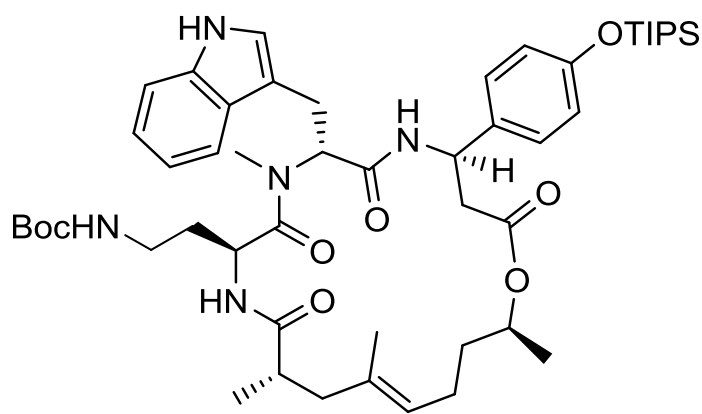

Diene $8 \mathbf{b}\left(39.0 \mathrm{mg}, 42.0 \mu \mathrm{mol}, 1.0\right.$ equiv.) was treated with a solution of $2^{\text {nd }}$ generation Grubbs catalyst $\left(3.7 \mathrm{mg}, 4.35 \mu \mathrm{mol}, 0.1\right.$ equiv., in $0.5 \mathrm{~mL} \mathrm{CH}_{2} \mathrm{Cl}_{2}$ ) according to the procedure described for the synthesis of compound 9a, to provide cyclopeptide $9 \mathbf{b}(23.8 \mathrm{mg}, 63 \%)$ as an off-white solid. $\mathrm{R}_{\mathrm{f}}=0.17($ EtOAc/Cyclohexan, $2: 1) ;[\alpha]_{D}^{23.8}=+35.8\left(c=1.0\right.$ in $\left.\mathrm{CHCl}_{3}\right) ;{ }^{1} \mathrm{H}$ NMR: $\left(600 \mathrm{MHz}, \mathrm{CDCl}_{3}\right.$ ): $\delta=1$ amino-hydrogen not observed, 8.32 (br s, 1H), 7.61 (d, $J=7.9 \mathrm{~Hz}, 1 \mathrm{H}), 7.33(\mathrm{~d}, J=8.1 \mathrm{~Hz}, 1 \mathrm{H}), 7.18(\mathrm{t}, J=7.5 \mathrm{~Hz}, 1 \mathrm{H}), 7.12(\mathrm{t}, J=7.5 \mathrm{~Hz}, 1 \mathrm{H})$, 7.12-7.10 (m, 1H), $7.06(\mathrm{~d}, J=8.4 \mathrm{~Hz}, 2 \mathrm{H}), 6.96(\mathrm{~s}, 1 \mathrm{H}), 6.80(\mathrm{~d}, J=8.4 \mathrm{~Hz}, 2 \mathrm{H}), 6.62(\mathrm{~d}$, $J=7.2 \mathrm{~Hz}, 1 \mathrm{H}), 5.68(\mathrm{dd}, J=10.0,6.3 \mathrm{~Hz}, 1 \mathrm{H}), 5.24-5.22(\mathrm{~m}, 1 \mathrm{H}), 5.02(\mathrm{t}, J=6.8 \mathrm{~Hz}, 1 \mathrm{H})$, 4.88-4.83 (m, 2H), 3.35 (dd, $J=15.7,6.1 \mathrm{~Hz}, 1 \mathrm{H}), 3.22$ (dd, $J=15.5,10.4 \mathrm{~Hz}, 2 \mathrm{H}), 2.89$ (s, $3 \mathrm{H}), 2.80(\mathrm{dd}, J=15.6,4.0 \mathrm{~Hz}, 1 \mathrm{H}), 2.64-2.56(\mathrm{~m}, 1 \mathrm{H}), 2.57(\mathrm{dd}, J=15.5,7.6 \mathrm{~Hz}, 1 \mathrm{H})$, 2.53-2.47 (m, 1H), 2.44-2.40 (m, 1H), $1.92(\mathrm{~d}, J=13.2 \mathrm{~Hz}, 1 \mathrm{H}), 1.84-1.79(\mathrm{~m}, 2 \mathrm{H}), 1.58-$ $1.49(\mathrm{~m}, 3 \mathrm{H}), 1.45(\mathrm{~s}, 3 \mathrm{H}), 1.43(\mathrm{~s}, 9 \mathrm{H}), 1.25-1.21(\mathrm{~m}, 4 \mathrm{H}), 1.18(\mathrm{~d}, J=6.8 \mathrm{~Hz}, 3 \mathrm{H}), 1.10(\mathrm{~d}$, 21H); ${ }^{13} \mathrm{C}-\mathrm{NMR}:\left(150 \mathrm{MHz} ; \mathrm{CDCl}_{3}\right): \delta=175.9,173.2,170.4,169.0,156.1,155.4,136.3$, 133.4, 132.7, 127.1, 127.0, 124.9, 122.4, 122.1, 119.9, 119.4, 118.6, 111.2, 110.7, 78.9, 77.2, 69.5, 55.8, 48.9, 47.0, 43.4, 39.6, 36.4, 35.5, 33.1, 29.7, 28.4, 23.3, 23.1, 20.5, 20.4, 17.9, 16.0, 12.6; IR: $\tilde{v}_{\max }=3321,2924,2854,1716,1635,1508,1265,1168$; HPLC: $t_{R}=17.87 \mathrm{~min}$ (C18 Gravity, method B); HRMS (ESI): m/Z calcd for $\mathrm{C}_{50} \mathrm{H}_{76} \mathrm{~N}_{5} \mathrm{O}_{8} \mathrm{Si}[\mathrm{M}+\mathrm{H}]^{+}: 902.5458$, found: 902.5458 . 
cyclo-[(2S,4E,8S)Hdn-L-Orn(Boc)-D-NMe-Trp- $\beta \operatorname{Tyr}($ OTIPS)] (9c):

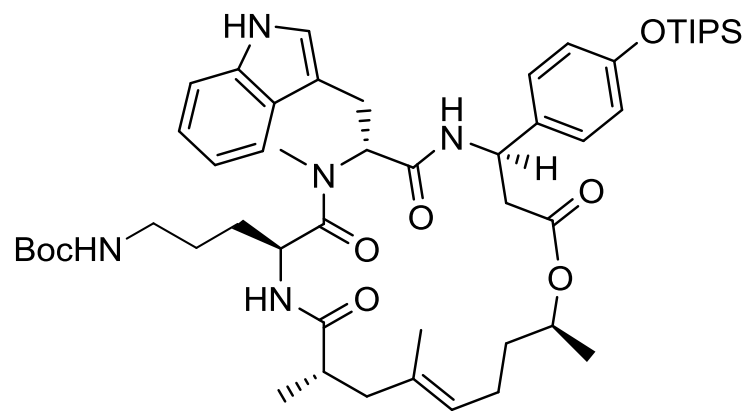

Diene $8 \mathrm{c}$ ( $75.0 \mathrm{mg}, 79.4 \mu \mathrm{mol}, 1.0$ equiv.) was treated with a solution of $2^{\text {nd }}$ generation Grubbs catalyst $\left(7.5 \mathrm{mg}, 8.82 \mu \mathrm{mol}, 0.1\right.$ equiv., in $\left.0.5 \mathrm{~mL} \mathrm{CH}_{2} \mathrm{Cl}_{2}\right)$ according to the procedure described for the synthesis of compound 9a, to provide cyclopeptide 9c (54 mg, 74\%) as an off-white solid. $\mathrm{R}_{\mathrm{f}}=0.15($ EtOAc/Cyclohexan, $2: 1) ;[\alpha]_{D}^{22.8}=+46.2\left(c=1.0\right.$ in $\left.\mathrm{CHCl}_{3}\right) ;{ }^{1} \mathrm{H}$ NMR: $\left(600 \mathrm{MHz}, \mathrm{CDCl}_{3}\right): \delta=1$ amino-hydrogen not observed, $9.56(\mathrm{br}, 1 \mathrm{H}), 7.65$ (d, $J=7.8 \mathrm{~Hz}, 1 \mathrm{H}), 7.42(\mathrm{~d}, J=8.1 \mathrm{~Hz}, 1 \mathrm{H}), 7.37(\mathrm{~d}, J=8.4 \mathrm{~Hz}, 1 \mathrm{H}), 7.20(\mathrm{t}, J=7.9 \mathrm{~Hz}, 1 \mathrm{H})$, $7.17-7.11(\mathrm{~m}, 3 \mathrm{H}), 6.95(\mathrm{~s}, 1 \mathrm{H}), 6.86(\mathrm{~d}, J=8.5 \mathrm{~Hz}, 2 \mathrm{H}), 6.66(\mathrm{~d}, J=6.1 \mathrm{~Hz}, 1 \mathrm{H}), 5.76$ (dd, $J=12.1,4.8 \mathrm{~Hz}, 1 \mathrm{H}), 5.26(\mathrm{~m}, 1 \mathrm{H}), 5.04(\mathrm{t}, J=6.5 \mathrm{~Hz}, 1 \mathrm{H}), 4.91$ (q, $J=4.8 \mathrm{~Hz}, 1 \mathrm{H}), 4.86-$ 4.79 (m, 1H), 3.49 (dd, $J=16.4,12.0 \mathrm{~Hz}, 1 \mathrm{H}), 3.26$ (dd, $J=16.4,4.7 \mathrm{~Hz}, 1 \mathrm{H}), 3.08-3.00$ (m, $1 \mathrm{H}), 2.86(\mathrm{~s}, 3 \mathrm{H}), 2.81(\mathrm{dd}, J=15.5,4.1 \mathrm{~Hz}, 1 \mathrm{H}), 2.73-2.66(\mathrm{~m}, 1 \mathrm{H}), 2.60(\mathrm{dd}, J=15.4$, $7.6 \mathrm{~Hz}, 1 \mathrm{H}), 2.49$ (d, $J=9.0 \mathrm{~Hz}, 2 \mathrm{H}), 2.01-1.80(\mathrm{~m}, 6 \mathrm{H}), 1.53$ (s, 9H), 1.50 (s, 3H), 1.33-1.24 $(\mathrm{m}, 4 \mathrm{H}), 1.18(\mathrm{~d}, J=5.6 \mathrm{~Hz}, 3 \mathrm{H}), 1.10(\mathrm{~d}, 21 \mathrm{H}, J=7.2 \mathrm{~Hz}), 1.04-0.95(\mathrm{~m}, 2 \mathrm{H}) ;{ }^{13} \mathrm{C}-\mathrm{NMR}$ : $\left(150 \mathrm{MHz} ; \mathrm{CDCl}_{3}\right): \delta=174.6,173.7,170.5,169.1,156.3,155.4,136.3,133.9,132.9,127.3$, $127.1,124.4,121.8,121.7,119.9,119.1,118.4,111.4,110.2,79.7,77.2$, 69.5, 61.8, 55.7, 49.2, 49.0, 43.2, 40.4, 39.6, 35.5, 30.1, 29.7, 28.5, 23.2, 22.7, 20.4, 20.4, 17.9, 16.2, 12.6; HPLC: $t_{R}=17.73 \mathrm{~min}\left(\mathrm{C} 18\right.$ Gravity, method $B$ ); HRMS (ESI): $\mathrm{m} / \mathrm{Z}$ calcd for $\mathrm{C}_{51} \mathrm{H}_{78} \mathrm{~N}_{5} \mathrm{O}_{8} \mathrm{Si}$ $[\mathrm{M}+\mathrm{H}]^{+}:$: 916.5614 , found: 916.5635 . 
cyclo-[(2S,4E,8S)Hdn-Dap(Tdpa)-D-NMe-Trp- $\beta$ Tyr] (optojasp-1):

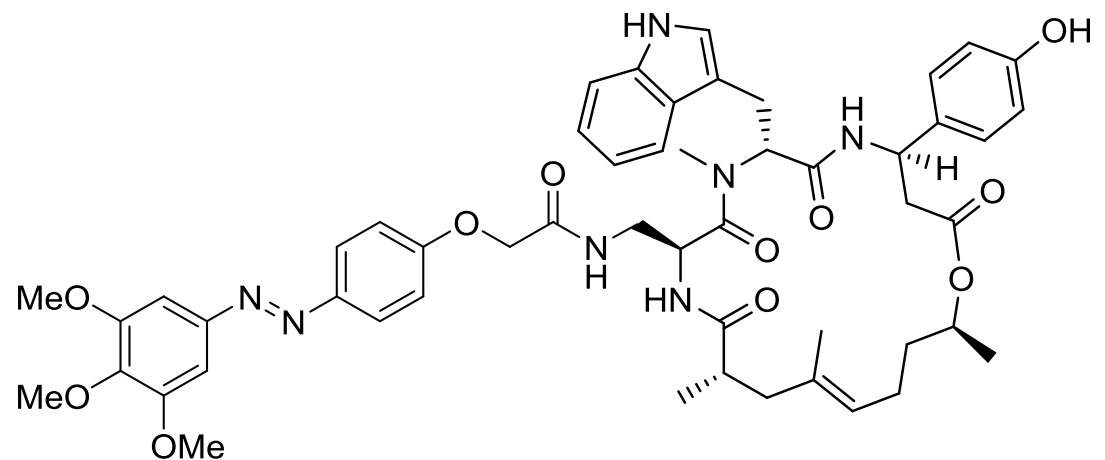

$\mathrm{HCl}$ in dioxane $(4 \mathrm{M}, 200 \mu \mathrm{L})$ was added to a solution of Boc-protected compound 9a (13.0 mg, $14.6 \mu \mathrm{mol}, 1.0$ equiv.) in $\mathrm{CH}_{2} \mathrm{Cl}_{2}(220 \mu \mathrm{L})$ under an atmosphere of argon at $0^{\circ} \mathrm{C}$. After stirring for $2.5 \mathrm{~h}$, the reaction mixture was concentrated under reduced pressure to afford crude acid 10a (LC-MS (ESI): $t_{R}=5.37 \mathrm{~min}$ (C18 Gravity, method $C$ ), $\mathrm{m} / \mathrm{Z}$ calcd for $\mathrm{C}_{44} \mathrm{H}_{66} \mathrm{~N}_{5} \mathrm{O}_{6}[\mathrm{M}+\mathrm{H}]^{+}:$788.5, found: 788.7). The residue was dissolved in THF (200 $\left.\mu \mathrm{L}\right)$ and was added to a solution of Azo-1 (5.1 mg, $14.6 \mu \mathrm{mol}, 1.0$ equiv.), HATU (13.4 mg, $35.1 \mu \mathrm{mol}, 2.4$ equiv.) and $N, N$-diisopropylethylamine $(19.9 \mu \mathrm{L}, 117.1 \mu \mathrm{mol}, 8.0$ equiv.) in THF $(200 \mu \mathrm{L})$ under an atmosphere of argon. After stirring at room temperature for $4 \mathrm{~h}$, the reaction mixture was filtered through silica-gel and evaporated to dryness. The residue was dissolved in THF $(400 \mu \mathrm{L})$ and hydrogen fluoride pyridine $(24 \mu \mathrm{L}, 70 \%)$ was added and stirred at room temperature for $18 \mathrm{~h}$. The reaction mixture was concentrated under nitrogen flow and directly purified by silica-gel chromatography $\left(1: 1 \mathrm{CH}_{2} \mathrm{Cl}_{2} /\right.$ acetone $)$ to provide optojasp-1 (11.6 mg, 71\%) as an orange solid. $\mathrm{R}_{\mathrm{f}}=0.19 \quad\left(1: 1 \mathrm{CH}_{2} \mathrm{Cl}_{2}\right.$ /acetone); $[\alpha]_{D}^{25.5}=+36.7\left(c=1.0\right.$ in $\left.\mathrm{CHCl}_{3}\right) ;{ }^{1} \mathrm{H}-\mathrm{NMR}, E$-isomer: $\left(600 \mathrm{MHz}, \mathrm{DMSO}-\mathrm{d}_{6}\right): \delta=10.64(\mathrm{~s}$, 1H), $9.09(\mathrm{~s}, 1 \mathrm{H}), 8.24(\mathrm{~d}, J=8.6 \mathrm{~Hz}, 1 \mathrm{H}), 7.86(\mathrm{~d}, J=8.8 \mathrm{~Hz}, 2 \mathrm{H}), 7.76(\mathrm{t}, J=5.8 \mathrm{~Hz}, 1 \mathrm{H})$, $7.65(\mathrm{~d}, J=7.9 \mathrm{~Hz}, 1 \mathrm{H}), 7.38(\mathrm{~d}, J=8.4 \mathrm{~Hz}, 1 \mathrm{H}), 7.32(\mathrm{~d}, J=8.1 \mathrm{~Hz}, 1 \mathrm{H}), 7.22(\mathrm{~s}, 2 \mathrm{H}), 7.11$ $(\mathrm{d}, J=9.0 \mathrm{~Hz}, 2 \mathrm{H}), 7.07-7.02(\mathrm{~m}, 3 \mathrm{H}), 7.01(\mathrm{~d}, J=2.0 \mathrm{~Hz}, 1 \mathrm{H}), 6.96(\mathrm{t}, J=7.5 \mathrm{~Hz}, 1 \mathrm{H}), 6.68$ $(\mathrm{d}, J=8.6 \mathrm{~Hz}, 2 \mathrm{H}), 5.49(\mathrm{dd}, J=6.5,9.4 \mathrm{~Hz}, 1 \mathrm{H}), 5.22-5.17(\mathrm{~m}, J=3.4,19.0 \mathrm{~Hz}, 1 \mathrm{H}), 5.00$ (t, $J=7.0 \mathrm{~Hz}, 1 \mathrm{H}), 4.97(\mathrm{dt}, J=4.2,8.6 \mathrm{~Hz}, 1 \mathrm{H}), 4.74(\mathrm{sxt}, J=6.3 \mathrm{~Hz}, 1 \mathrm{H}), 4.49$ (d, $J=2.4$ $\mathrm{Hz}, 2 \mathrm{H}), 3.90$ (s, 6H), 3.79 (s, 3H), $3.11(\mathrm{~s}, 3 \mathrm{H}), 3.09$ (d, $J=6.4 \mathrm{~Hz}, 1 \mathrm{H}), 3.02(\mathrm{dd}, J=9.5$, $15.0 \mathrm{~Hz}, 1 \mathrm{H}), 3.00-2.96(\mathrm{~m}, J=5.7 \mathrm{~Hz}, 1 \mathrm{H}), 2.81-2.75(\mathrm{~m}, J=5.9 \mathrm{~Hz}, 1 \mathrm{H}), 2.69(\mathrm{dd}, J=$ 10.6, 15.2 Hz, 1H), 2.62 (dd, $J=3.7,15.2 \mathrm{~Hz}, 1 \mathrm{H}), 2.56-2.53(\mathrm{~m}, 1 \mathrm{H}), 2.20$ (dd, $J=11.1$, $14.2 \mathrm{~Hz}, 1 \mathrm{H}), 1.92-1.84(\mathrm{~m}, J=7.0 \mathrm{~Hz}, 2 \mathrm{H}), 1.81(\mathrm{~d}, J=13.4 \mathrm{~Hz}, 1 \mathrm{H}), 1.52$ (s, 3H), 1.59 1.49 (m, 1H), 1.47-1.38 (m, $J=6.9,13.9 \mathrm{~Hz}, 1 \mathrm{H}), 1.15$ (d, $J=6.4 \mathrm{~Hz}, 3 \mathrm{H}), 0.98$ (d, $J=6.8$ $\mathrm{Hz}, 3 \mathrm{H}) ;{ }^{13} \mathrm{C}-\mathrm{NMR}$ : $E$-isomer (126 MHz; DMSO-d 6 ): $\delta=175.5,170.7,170.5,170.0,168.0$, $160.6,156.7,153.8,148.3,146.8,140.3,136.6$, 133.5, 133.2, 127.6, 127.4, 124.8, 123.8, 
$123.7,121.3,119.2,118.5,115.8,115.5,111.6,110.0,100.4,71.2,67.4,60.7,56.5,55.3$, $49.3,48.5,43.2,41.9,40.7,38.3,35.4,31.0,25.8,24.1,20.0,19.8,17.2 ;$ IR: $\widetilde{v}_{\max }=3733$, 3672, 3594, 2974, 2901, 1711, 1511, 1397, 1250, 1227, 1056, 670, 652; UV-VIS: $\lambda_{\max }$ $\left(\mathrm{CH}_{3} \mathrm{CN}\right)=E$-isomer.: $360 \mathrm{~nm}, \varepsilon_{360}=17.4 \times 10^{3} \mathrm{~L} \cdot \mathrm{mol}^{-1} \cdot \mathrm{cm}^{-1}, Z$-isomer: $441 \mathrm{~nm}, \varepsilon_{441}=1.80 \mathrm{x}$ $10^{3} \mathrm{~L} \cdot \mathrm{mol}^{-1} \cdot \mathrm{cm}^{-1}$; HPLC: $(\mathrm{C} 18$ Gravity, $\operatorname{method} C) \mathrm{t}_{\mathrm{R}},(Z)=10.23 \mathrm{~min}, \mathrm{t}_{\mathrm{R}},(E)=11.40 \mathrm{~min}$; HRMS (ESI): $\mathrm{m} / \mathrm{Z}$ calcd for $\mathrm{C}_{52} \mathrm{H}_{62} \mathrm{~N}_{7} \mathrm{O}_{11}[\mathrm{M}+\mathrm{H}]^{+}: 960,4502$, found: 960,$4512 ; \mathrm{m} / \mathrm{Z}$ calcd for $\mathrm{C}_{52} \mathrm{H}_{61} \mathrm{~N}_{7} \mathrm{O}_{11} \mathrm{Na}[\mathrm{M}+\mathrm{Na}]^{+}$, 982.4321, found: 982.4333 .

cyclo-[(2S,4E,8S)Hdn-Dab(Tdpa)-D-NMe-Trp- $\beta$ Tyr] (optojasp-2):

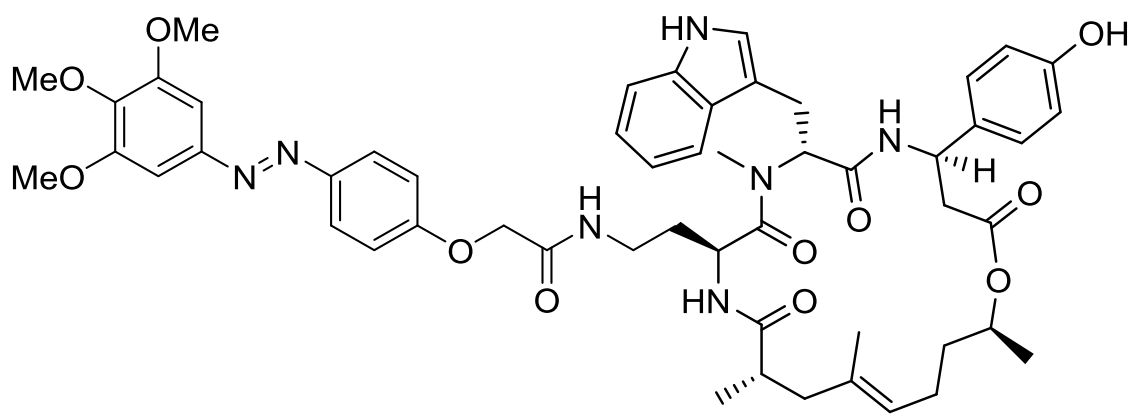

Boc-protected compound $9 \mathbf{b}(10.0 \mathrm{mg}, 11.1 \mu \mathrm{mol}, 1.0$ equiv.) was treated according to the procedure described for the synthesis of optojasp-1 with $\mathrm{HCl}$ to afford crude acid 10b (LCMS (ESI): $t_{R}=7.65$ min $(\mathrm{C} 18$ Gravity, method $B), \mathrm{m} / \mathrm{Z}$ calcd for $\mathrm{C}_{45} \mathrm{H}_{68} \mathrm{~N}_{5} \mathrm{O}_{6}[\mathrm{M}+\mathrm{H}]^{+}: 802.5$, found: 803.1). The crude product was treated with Azo-1 (3.8 mg, $11.1 \mu \mathrm{mol}, 1.0$ equiv.), HATU (10.1 mg, $26.6 \mu \mathrm{mol}, 2.4$ equiv.) and $N, N$-diisopropylethylamine (15.1 $\mu 1,88.7 \mu \mathrm{mol}$, 8.0 equiv.). Finally the residue was treated with hydrogen fluoride pyridine to provide optojasp-2 $(6.3 \mathrm{mg}, 54 \%)$ as an orange solid after silica-gel chromatography (1:1 $\mathrm{CH}_{2} \mathrm{Cl}_{2}$ /acetone). $\mathrm{R}_{\mathrm{f}}=0.18\left(1: 1 \mathrm{CH}_{2} \mathrm{Cl}_{2}\right.$ /acetone $) ;[\alpha]_{D}^{25.5}=+29.8\left(c=0.9\right.$ in $\left.\mathrm{CHCl}_{3}\right) ;{ }^{1} \mathrm{H}-$ NMR, E-isomer: (600 MHz, DMSO-d $\left.{ }_{6}\right): \delta=10.74$ (d, $\left.J=1.5 \mathrm{~Hz}, 1 \mathrm{H}\right), 9.27$ (br. s., $\left.1 \mathrm{H}\right), 8.51$ $(\mathrm{d}, J=8.8 \mathrm{~Hz}, 1 \mathrm{H}), 7.89(\mathrm{t}, J=6.2 \mathrm{~Hz}, 1 \mathrm{H}), 7.88(\mathrm{~d}, J=8.8 \mathrm{~Hz}, 2 \mathrm{H}), 7.82(\mathrm{~d}, J=8.6 \mathrm{~Hz}, 1 \mathrm{H})$, $7.62(\mathrm{~d}, J=7.9 \mathrm{~Hz}, 1 \mathrm{H}), 7.28(\mathrm{~d}, J=8.1 \mathrm{~Hz}, 1 \mathrm{H}), 7.22$ (s, 2H), 7.14 (d, $J=9.0 \mathrm{~Hz}, 2 \mathrm{H}), 7.05-$ $7.00(\mathrm{~m}, J=8.6 \mathrm{~Hz}, 3 \mathrm{H}), 6.97(\mathrm{~d}, J=1.8 \mathrm{~Hz}, 1 \mathrm{H}), 6.94(\mathrm{t}, J=7.4 \mathrm{~Hz}, 1 \mathrm{H}), 6.65$ (d, $J=8.4$ $\mathrm{Hz}, 2 \mathrm{H}), 5.46(\mathrm{dd}, J=6.8,9.0 \mathrm{~Hz}, 1 \mathrm{H}), 5.15(\mathrm{ddd}, J=3.3,8.5,11.2 \mathrm{~Hz}, 1 \mathrm{H}), 4.95(\mathrm{t}, J=6.6$ $\mathrm{Hz}, 1 \mathrm{H}), 4.72-4.65(\mathrm{~m}, 2 \mathrm{H}), 4.56(\mathrm{~s}, 2 \mathrm{H}), 3.87$ (s, 6H), $3.74(\mathrm{~s}, 3 \mathrm{H}), 2.97$ (s, 3H), 3.07-2.92 (m, 3H), 2.83-2.74 (m, $J=7.3 \mathrm{~Hz}, 1 \mathrm{H}), 2.64$ (dd, $J=11.1,15.1 \mathrm{~Hz}, 1 \mathrm{H}), 2.61-2.54(\mathrm{~m}, 2 \mathrm{H})$, 2.21-2.14 (m, $J=13.2 \mathrm{~Hz}, 1 \mathrm{H}), 1.89-1.80(\mathrm{~m}, 2 \mathrm{H}), 1.77$ (d, $J=13.4 \mathrm{~Hz}, 1 \mathrm{H}), 1.60-1.52$ (m, 2H), $1.49(\mathrm{~s}, 3 \mathrm{H}), 1.52-1.43(\mathrm{~m}, 1 \mathrm{H}), 1.40-1.34(\mathrm{~m}, 1 \mathrm{H}), 1.11(\mathrm{~d}, J=6.2 \mathrm{~Hz}, 3 \mathrm{H}), 0.96(\mathrm{~d}, J$ $=6.6 \mathrm{~Hz}, 3 \mathrm{H}) ;{ }^{13} \mathrm{C}-\mathrm{NMR}$ : E-isomer $(126 \mathrm{MHz}$; DMSO-d 6 ): $\delta=175.4,172.1,170.7,170.0$, 
$167.5,160.7,156.7,153.8,148.3,146.9,140.3,136.6,133.6,133.2,127.5,127.5,124.8$, $123.9,123.6,121.3,119.0,118.6,115.9,115.5,111.6,110.0,100.5,71.2$, 67.6, 60.7, 56.4, $55.3,49.3,46.5,43.3,41.8,38.3,35.4,35.2,30.8,29.5,25.8,24.0,20.0,19.9$, 17.2; IR: $\tilde{v}_{\max }=3734,3626,3590,2974,2901,1710,1672,1512,1396,1226,1053,671,652$; UVVIS: $\lambda_{\max }\left(\mathrm{CH}_{3} \mathrm{CN}\right)=E$-isomer.: $361 \mathrm{~nm}, \varepsilon_{361}=17.2 \times 10^{3} \mathrm{~L} \cdot \mathrm{mol}^{-1} \cdot \mathrm{cm}^{-1}, Z$-isomer: $441 \mathrm{~nm}$, $\varepsilon_{441}=1.62 \times 10^{3} \mathrm{~L} \cdot \mathrm{mol}^{-1} \cdot \mathrm{cm}^{-1}$; HPLC: $(\mathrm{C} 18$ Gravity, method $C) \mathrm{t}_{\mathrm{R}},(Z)=10.0 \mathrm{~min}, \mathrm{t}_{\mathrm{R}},(E)=$ 11.2 min; HRMS (ESI): m/z calcd for $\mathrm{C}_{53} \mathrm{H}_{64} \mathrm{~N}_{7} \mathrm{O}_{11}[\mathrm{M}+\mathrm{H}]^{+}$: 974.4659, found: 974.4670 .

cyclo-[(2S,4E,8S)Hdn-Orn(Tdpa)-D-NMe-Trp- $\beta$ Tyr] (optojasp-3):<smiles>COc1cc(N=Nc2ccc(OCC(=O)NCCC[C@@H]3NC(=O)[C@H](C)C/C(C)=C/CC[C@H](C)OC(=O)C[C@@H](c4ccc(O)cc4)NC(=O)[C@@H](Cc4c[nH]c5ccccc45)N(C)C3=O)cc2)cc(OC)c1OC</smiles>

Boc-protected compound 9c (18.0 mg, $19.7 \mu \mathrm{mol}, 1.0$ equiv.) was treated according to the procedure described for the synthesis of optojasp-1 with $\mathrm{HCl}$ to afford crude acid 10c. LCMS (ESI): $t_{R}=5.44$ min (C18 Gravity, method $\left.C\right), \mathrm{m} / \mathrm{Z}$ calcd for $\mathrm{C}_{46} \mathrm{H}_{70} \mathrm{~N}_{5} \mathrm{O}_{6}[\mathrm{M}+\mathrm{H}]^{+}: 816.5$, found: 816.7 .

Then the crude product was treated with Azo-1 (6.8 mg, $19.7 \mu$ mol, 1.0 equiv.), HATU (17.9 mg, $47.2 \mu \mathrm{mol}, 2.4$ equiv.) and $N, N$-diisopropylethylamine (27.0 $\mu 1,157 \mu \mathrm{mol}$, 8.0 equiv.). Finally the residue was treated with hydrogen fluoride pyridine to provide optojasp-3 (13 mg, 67\%) as an orange solid after silica-gel chromatography (1:1 $\mathrm{CH}_{2} \mathrm{Cl}_{2}$ /acetone). $\mathrm{R}_{\mathrm{f}}=0.19\left(1: 1 \mathrm{CH}_{2} \mathrm{Cl}_{2}\right.$ /acetone); $[\alpha]_{D}^{22.8}=+26.6\left(c=0.44\right.$ in $\left.\mathrm{CHCl}_{3}\right) ;{ }^{1} \mathrm{H}-$ NMR, $E$-isomer: (600 MHz, DMSO-d $\left.)_{6}\right): \delta=10.78$ (d, $\left.J=1.5 \mathrm{~Hz}, 1 \mathrm{H}\right), 9.31$ (br. s., $\left.1 \mathrm{H}\right), 8.61$ $(\mathrm{d}, J=8.8 \mathrm{~Hz}, 1 \mathrm{H}), 7.95(\mathrm{t}, J=5.7 \mathrm{~Hz}, 1 \mathrm{H}), 7.88(\mathrm{~d}, J=9.0 \mathrm{~Hz}, 2 \mathrm{H}), 7.74(\mathrm{~d}, J=8.6 \mathrm{~Hz}, 1 \mathrm{H})$, $7.66(\mathrm{~d}, J=7.9 \mathrm{~Hz}, 1 \mathrm{H}), 7.31(\mathrm{~d}, J=8.1 \mathrm{~Hz}, 1 \mathrm{H}), 7.22(\mathrm{~s}, 2 \mathrm{H}), 7.12(\mathrm{~d}, J=9.0 \mathrm{~Hz}, 2 \mathrm{H}), 7.10$ $(\mathrm{d}, J=8.6 \mathrm{~Hz}, 2 \mathrm{H}), 7.06-7.01(\mathrm{~m}, J=7.0 \mathrm{~Hz}, 2 \mathrm{H}), 6.96(\mathrm{t}, J=7.6 \mathrm{~Hz}, 1 \mathrm{H}), 6.69(\mathrm{~d}, J=8.6$ $\mathrm{Hz}, 2 \mathrm{H}), 5.51(\mathrm{dd}, J=5.5,10.8 \mathrm{~Hz}, 1 \mathrm{H}), 5.18(\mathrm{ddd}, J=2.9,9.0,11.4 \mathrm{~Hz}, 1 \mathrm{H}), 4.93(\mathrm{t}, J=6.6$ $\mathrm{Hz}, 1 \mathrm{H}), 4.68(\mathrm{sxt}, J=6.4 \mathrm{~Hz}, 1 \mathrm{H}), 4.61(\mathrm{dt}, J=4.7,8.6 \mathrm{~Hz}, 1 \mathrm{H}), 4.55(\mathrm{~s}, 2 \mathrm{H}), 3.88(\mathrm{~s}, 6 \mathrm{H})$, $3.76(\mathrm{~s}, 3 \mathrm{H}), 3.04(\mathrm{~s}, 3 \mathrm{H}), 3.08-2.99(\mathrm{~m}, 2 \mathrm{H}), 2.95(\mathrm{dd}, J=5.3,14.7 \mathrm{~Hz}, 1 \mathrm{H}), 2.88(\mathrm{tt}, J=6.5$, $13.2 \mathrm{~Hz}, 1 \mathrm{H}), 2.83(\mathrm{tt}, J=6.3,12.9 \mathrm{~Hz}, 1 \mathrm{H}), 2.67(\mathrm{dd}, J=11.3,14.9 \mathrm{~Hz}, 1 \mathrm{H}), 2.59(\mathrm{dd}, J=$ 
2.9, $14.7 \mathrm{~Hz}, 1 \mathrm{H}), 2.17(\mathrm{dd}, J=11.9,14.3 \mathrm{~Hz}, 1 \mathrm{H}), 1.91-1.77(\mathrm{~m}, J=7.2,12.0 \mathrm{~Hz}, 2 \mathrm{H}), 1.74$ (d, $J=14.3 \mathrm{~Hz}, 1 \mathrm{H}), 1.48$ (s, 3H), 1.53-1.46 (m, 1H), 1.43-1.33 (m, 1H), 1.15 (d, $J=6.4 \mathrm{~Hz}$, $3 \mathrm{H}), 1.08-0.99(\mathrm{~m}, 2 \mathrm{H}), 0.93(\mathrm{~d}, J=6.8 \mathrm{~Hz}, 3 \mathrm{H}), 0.90-0.78(\mathrm{~m}, 2 \mathrm{H}) ;{ }^{13} \mathrm{C}-\mathrm{NMR}: E$-isomer $\left(126 \mathrm{MHz} ;\right.$ DMSO-d $\left.{ }_{6}\right): \delta=175.0,172.5,170.8,170.4,167.4,160.7,156.7,153.8,148.3$, $146.8,140.3$, 136.6, 133.6, 133.4, 127.5, 127.5, 124.8, 123.8, 123.6, 121.3, 119.1, 118.6, $115.8,115.5,111.6,110.0,100.4,71.3,67.6,60.7,56.4,55.1,49.4,48.0,43.1,42.0,38.5$, 38.2, 35.3, 31.0, 29.1, 26.0, 25.3, 24.1, 20.1, 20.0, 17.3; IR: $\tilde{v}_{\max }=3734,3672,3595,2974$, 2900, 1710, 1514, 1394, 1227, 1053, 671, 652; UV-VIS: $\lambda_{\max }\left(\mathrm{CH}_{3} \mathrm{CN}\right)=E$-isomer.: $360 \mathrm{~nm}$, $\varepsilon_{360}=17301 \mathrm{l} \cdot \mathrm{mol}-1 \cdot \mathrm{cm}-1$, Z-isomer: $439 \mathrm{~nm}, \varepsilon_{439}=16051 \cdot \mathrm{mol}-1 \cdot \mathrm{cm}-1 ;$ HPLC: $(\mathrm{C} 18$ Gravity, method $C) \mathrm{t}_{\mathrm{R}},(Z)=10.23$ min, $\mathrm{t}_{\mathrm{R}},(E)=11.29 \mathrm{~min} ; \mathrm{HRMS}(\mathrm{ESI}): \mathrm{m} / \mathrm{Z}$ calcd for $\mathrm{C}_{54} \mathrm{H}_{66} \mathrm{~N}_{7} \mathrm{O}_{11}$ $[\mathrm{M}+\mathrm{H}]^{+}:$988.4815, found: $988.4829 ; \mathrm{m} / \mathrm{Z}$ calcd for $\mathrm{C}_{54} \mathrm{H}_{65} \mathrm{~N}_{7} \mathrm{O}_{11} \mathrm{Na}[\mathrm{M}+\mathrm{Na}]^{+}, 1010.4634$, found: 1010.4649 .

cyclo-[(2S,4E,8S)Hdn-Lys(Tdpa)-D-NMe-Trp- $\beta$ Tyr] (optojasp-4):

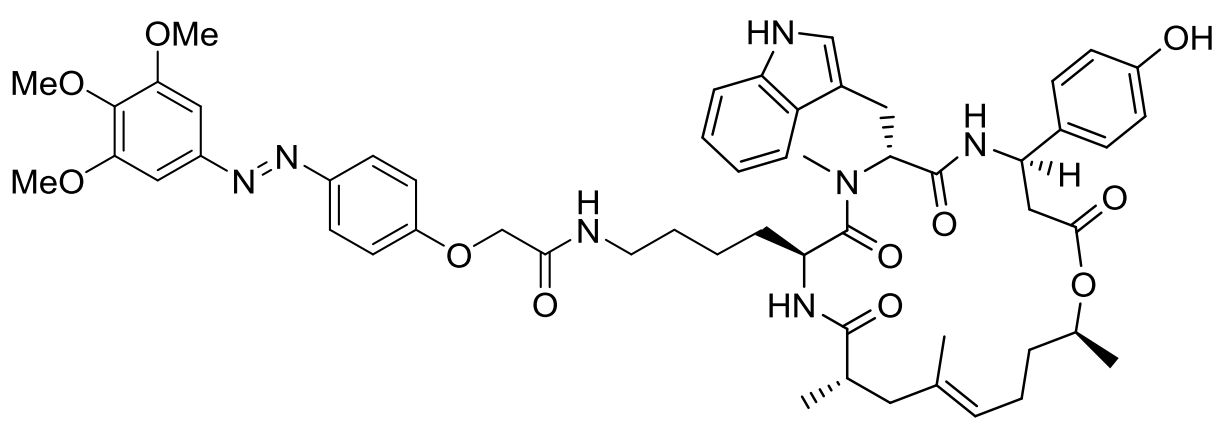

Boc-protected compound 9d (10.0 mg, $10.8 \mu \mathrm{mol}, 1.0$ equiv.) was treated according to the procedure described for the synthesis of optojasp-1. At first with $\mathrm{HCl}$ to afford crude acid 10d. LC-MS (ESI): $t_{R}=5.67$ min (C18 Gravity, method $C$ ), $\mathrm{m} / \mathrm{Z}$ calcd for $\mathrm{C}_{47} \mathrm{H}_{72} \mathrm{~N}_{5} \mathrm{O}_{6}$ $[\mathrm{M}+\mathrm{H}]^{+}: 830.5$, found: 831.2 .

Then the crude product was treated with Azo-1 (3.7 mg, $10.8 \mu \mathrm{mol}, 1.0$ equiv.), HATU (9.8 mg, $25.8 \mu \mathrm{mol}, 2.4$ equiv.) and $N, N$-diisopropylethylamine (14.6 $\mu 1,86 \mu \mathrm{mol}$, 8.0 equiv.). Finally the residue was treated with hydrogen fluoride pyridine to provide optojasp-4 (5.3 mg, 48\%) as an orange solid after silica-gel chromatography (1:1 $\mathrm{CH}_{2} \mathrm{Cl}_{2}$ /acetone). $\mathrm{R}_{\mathrm{f}}=0.18\left(1: 1 \mathrm{CH}_{2} \mathrm{Cl}_{2}\right.$ /acetone $) ;[\alpha]_{D}^{25.3}=+31.8\left(c=0.3\right.$ in $\left.\mathrm{CHCl}_{3}\right) ;{ }^{1} \mathrm{H}-$ NMR, $E$-isomer: (500 MHz, DMSO-d $\left.{ }_{6}\right): \delta=10.81(\mathrm{~d}, J=1.6 \mathrm{~Hz}, 1 \mathrm{H}), 9.35$ (br. s., $\left.1 \mathrm{H}\right), 8.65$ $(\mathrm{d}, J=8.9 \mathrm{~Hz}, 1 \mathrm{H}), 8.09(\mathrm{t}, J=6.0 \mathrm{~Hz}, 1 \mathrm{H}), 7.90(\mathrm{~d}, J=8.9 \mathrm{~Hz}, 2 \mathrm{H}), 7.73(\mathrm{~d}, J=8.5 \mathrm{~Hz}, 1 \mathrm{H})$, $7.67(\mathrm{~d}, J=7.9 \mathrm{~Hz}, 1 \mathrm{H}), 7.29$ (d, $J=8.2 \mathrm{~Hz}, 1 \mathrm{H}), 7.23(\mathrm{~s}, 2 \mathrm{H}), 7.15(\mathrm{~d}, J=9.2 \mathrm{~Hz}, 2 \mathrm{H}), 7.13$ $(\mathrm{d}, J=8.5 \mathrm{~Hz}, 2 \mathrm{H}), 7.06(\mathrm{~d}, J=2.1 \mathrm{~Hz}, 1 \mathrm{H}), 7.03(\mathrm{t}, J=7.3 \mathrm{~Hz}, 1 \mathrm{H}), 6.95(\mathrm{t}, J=7.3 \mathrm{~Hz}, 1 \mathrm{H})$, 
$6.70(\mathrm{~d}, J=8.5 \mathrm{~Hz}, 2 \mathrm{H}), 5.52(\mathrm{dd}, J=5.0,11.4 \mathrm{~Hz}, 1 \mathrm{H}), 5.19$ (ddd, $J=2.9,9.0,11.3 \mathrm{~Hz}, 1 \mathrm{H})$, $4.93(\mathrm{t}, J=6.6 \mathrm{~Hz}, 1 \mathrm{H}), 4.67$ (sxt, $J=6.4 \mathrm{~Hz}, 1 \mathrm{H}), 4.59$ (s, 2H), 4.61-4.54 (m, 1H), 3.88 (s, $6 \mathrm{H}), 3.76(\mathrm{~s}, 3 \mathrm{H}), 3.04$ (s, 3H), 3.08-2.88 (m, 5H), 2.68 (dd, $J=11.6,14.6 \mathrm{~Hz}, 1 \mathrm{H}), 2.59$ (dd, $J=3.1,14.6 \mathrm{~Hz}, 1 \mathrm{H}), 2.18(\mathrm{dd}, J=12.2,15.3 \mathrm{~Hz}, 1 \mathrm{H}), 1.92-1.76(\mathrm{~m}, J=7.3 \mathrm{~Hz}, 2 \mathrm{H}), 1.72$ (d, $J=14.3 \mathrm{~Hz}, 1 \mathrm{H}), 1.49$ (s, $3 \mathrm{H}), 1.54-1.45(\mathrm{~m}, 1 \mathrm{H}), 1.43-1.33(\mathrm{~m}, 1 \mathrm{H}), 1.16$ (d, $J=6.4 \mathrm{~Hz}$, $3 \mathrm{H}), 1.22-1.09(\mathrm{~m}, 2 \mathrm{H}), 0.92(\mathrm{~d}, J=6.7 \mathrm{~Hz}, 3 \mathrm{H}), 0.87-0.77(\mathrm{~m}, 3 \mathrm{H}), 0.73-0.62(\mathrm{~m}, 1 \mathrm{H}) ;{ }^{13} \mathrm{C}-$ NMR: $E$-isomer (150 MHz; DMSO-d $\left.{ }_{6}\right): \delta=174.5,172.3,170.3,170.1,167.0,160.2,156.3$, $153.3,147.8,146.4,139.9,136.1,133.1,133.0,127.1,127.0,124.3,123.4,123.0,120.8$, 118.7, 118.1, 115.4, 115.1, 111.2, 109.5, 100.0, 71.0, 67.1, 60.2, 56.0, 54.6, 49.0, 47.7, 42.5, $41.7,38.0,37.6,34.9,30.6,30.6,28.6,25.6,23.7,22.0,19.7,19.5,16.9$; IR: $\tilde{v}_{\max }=3735$, 3626, 3594, 2975, 2901, 1711, 1512, 1398, 1250, 1227, 1052, 670, 652; UV-VIS: $\lambda_{\max }$ $\left(\mathrm{CH}_{3} \mathrm{CN}\right)=E$-isomer.: $360 \mathrm{~nm}, \varepsilon_{360}=15.8 \times 10^{3} \mathrm{~L} \cdot \mathrm{mol}^{-1} \cdot \mathrm{cm}^{-1}, Z$-isomer: $442 \mathrm{~nm}, \varepsilon_{442}=1.49 \mathrm{x}$ $10^{3} \mathrm{~L} \cdot \mathrm{mol}^{-1} \cdot \mathrm{cm}^{-1}$; HPLC: (C18 Gravity, method $\left.C\right) \mathrm{t}_{\mathrm{R}},(Z)=10.05 \mathrm{~min}, \mathrm{t}_{\mathrm{R}},(E)=11.27 \mathrm{~min}$; HRMS (ESI): $\mathrm{m} / \mathrm{Z}$ calcd for $\mathrm{C}_{55} \mathrm{H}_{68} \mathrm{~N}_{7} \mathrm{O}_{11}[\mathrm{M}+\mathrm{H}]^{+}: 1002.4971$, found: $1002.4975 ; \mathrm{m} / \mathrm{Z}$ calcd for $\mathrm{C}_{55} \mathrm{H}_{67} \mathrm{~N}_{7} \mathrm{O}_{11} \mathrm{Na}[\mathrm{M}+\mathrm{Na}]^{+}, 1024.4791$, found: 1024.4796 .

cyclo-[(2S,4E,8S)Hdn-Dap(Mtdps)-D-NMe-Trp- $\beta$ Tyr] (optojasp-5):<smiles>COc1ccc(/N=N/c2cc(OC)c(OC)c(OC)c2)c(NC(=O)CCC(=O)NC[C@@H]2NC(=O)[C@H](C)C/C(C)=C/CC[C@H](C)OC(=O)C[C@@H](c3ccc(O)cc3)NC(=O)[C@H](Cc3c[nH]c4ccccc34)N(c3ccccc3)C2=O)c1</smiles>

Boc-protected compound 9a $(10.0 \mathrm{mg}, 11.3 \mu \mathrm{mol}, 1.0$ equiv.) was treated according to the procedure described for the synthesis of optojasp-1 with $\mathrm{HCl}$ to afford crude acid 10a. LCMS (ESI): $t_{R}=5.38$ min $(\mathrm{C} 18$ Gravity, method $C), \mathrm{m} / \mathrm{Z}$ calcd for $\mathrm{C}_{44} \mathrm{H}_{66} \mathrm{~N}_{5} \mathrm{O}_{6}[\mathrm{M}+\mathrm{H}]^{+}: 788.5$, found: 788.7 .

Then the crude product was treated with Azo-2 (4.7 mg, $11.3 \mu \mathrm{mol}, 1.0$ equiv.), HATU (10.3 mg, $27.0 \mu \mathrm{mol}, 2.4$ equiv.) and $N, N$-diisopropylethylamine (15.3 $\mu 1,90.1 \mu \mathrm{mol}$, 8.0 equiv.). Finally the residue was treated with hydrogen fluoride pyridine to provide optojasp-5 $(8.9 \mathrm{mg}, 77 \%)$ as an orange solid after silica-gel chromatography (1:1 
$\mathrm{CH}_{2} \mathrm{Cl}_{2}$ /acetone). $\mathrm{R}_{\mathrm{f}}=0.21\left(1: 1 \mathrm{CH}_{2} \mathrm{Cl}_{2}\right.$ /acetone $) ;[\alpha]_{D}^{25.5}=+16.9\left(c=1.0\right.$ in $\left.\mathrm{CHCl}_{3}\right) ;{ }^{1} \mathrm{H}-$ NMR, E-isomer: (600 MHz, DMSO-d 6 ): $\delta=10.77$ (s, 1H), 10.26 (s, 1H), 9.32 (br. s., 1H), $8.56(\mathrm{~d}, J=8.6 \mathrm{~Hz}, 1 \mathrm{H}), 7.99(\mathrm{~d}, J=2.9 \mathrm{~Hz}, 1 \mathrm{H}), 7.75(\mathrm{~d}, J=9.0 \mathrm{~Hz}, 1 \mathrm{H}), 7.71$ (t, $J=5.5 \mathrm{~Hz}$, $1 \mathrm{H}), 7.66(\mathrm{~d}, J=7.7 \mathrm{~Hz}, 1 \mathrm{H}), 7.61(\mathrm{~d}, J=8.6 \mathrm{~Hz}, 1 \mathrm{H}), 7.36(\mathrm{~s}, 2 \mathrm{H}), 7.29$ (d, $J=8.1 \mathrm{~Hz}, 1 \mathrm{H})$, $7.05(\mathrm{~d}, J=8.8 \mathrm{~Hz}, 2 \mathrm{H}), 7.02(\mathrm{~d}, J=7.9 \mathrm{~Hz}, 1 \mathrm{H}), 6.98(\mathrm{~d}, J=2.2 \mathrm{~Hz}, 1 \mathrm{H}), 6.94(\mathrm{t}, J=7.5 \mathrm{~Hz}$, $1 \mathrm{H}), 6.79(\mathrm{dd}, J=2.8,9.1 \mathrm{~Hz}, 1 \mathrm{H}), 6.67(\mathrm{~d}, J=8.4 \mathrm{~Hz}, 2 \mathrm{H}), 5.48(\mathrm{t}, J=8.1 \mathrm{~Hz}, 1 \mathrm{H}), 5.16$ (ddd, $J=3.1,8.6,11.4 \mathrm{~Hz}, 1 \mathrm{H}), 4.92(\mathrm{t}, J=6.7 \mathrm{~Hz}, 1 \mathrm{H}), 4.88(\mathrm{dt}, J=4.1,9.0 \mathrm{~Hz}, 1 \mathrm{H}), 4.67$ (sxt, $J=6.3 \mathrm{~Hz}, 1 \mathrm{H}), 3.89(\mathrm{~s}, 6 \mathrm{H}), 3.84(\mathrm{~s}, 3 \mathrm{H}), 3.76(\mathrm{~s}, 3 \mathrm{H}), 3.09-3.04(\mathrm{~m}, 3 \mathrm{H}), 2.97$ (d, $J=$ $8.1 \mathrm{~Hz}, 2 \mathrm{H}), 2.75-2.63(\mathrm{~m}, 5 \mathrm{H}), 2.59(\mathrm{dd}, J=3.1,15.0 \mathrm{~Hz}, 1 \mathrm{H}), 2.38-2.26(\mathrm{~m}, J=8.0,15.5$ $\mathrm{Hz}, 3 \mathrm{H}), 2.13(\mathrm{dd}, J=11.6,14.4 \mathrm{~Hz}, 1 \mathrm{H}), 1.90-1.77(\mathrm{~m}, J=7.9,15.7 \mathrm{~Hz}, 2 \mathrm{H}), 1.72(\mathrm{~d}, J=$ 14.1 Hz, 1H), 1.47 (s, 3H), 1.54-1.44 (m, 1H), 1.41-1.32 (m, 1H), $1.14(\mathrm{~d}, J=6.4 \mathrm{~Hz}, 3 \mathrm{H})$, $0.93(\mathrm{~d}, J=6.6 \mathrm{~Hz}, 3 \mathrm{H}) ;{ }^{13} \mathrm{C}-\mathrm{NMR}: E$-isomer (126 MHz, DMSO-d 6 ): $\delta=175.3,172.0,171.6$, $170.7,170.6,170.0,163.0,156.7,153.7,148.6,140.3,139.2$, 136.5, 134.9, 133.5, 133.3, $127.5,127.4,123.8,123.6,121.3,119.2$, 118.8, 118.5, 115.5, 111.6, 110.5, 110.0, 106.2, $101.1,71.2,60.7,56.5,56.0,55.6,49.3,48.5,43.2,41.9,40.8,38.3,35.3,32.4,30.9,30.5$, 26.0, 24.0, 20.0, 19.8, 17.2; IR: $\tilde{v}_{\max }=3730,3626,3594,2959,2924,1667,1523,1458$, 1234, 1126, 1056, 671, 652; UV-VIS: $\lambda_{\max }\left(\mathrm{CH}_{3} \mathrm{CN}\right)=E$-isomer.: $391 \mathrm{~nm}, \varepsilon_{391}=17.3 \times 10^{3}$ $\mathrm{L} \cdot \mathrm{mol}^{-1} \cdot \mathrm{cm}^{-1}, Z$-isomer: $452 \mathrm{~nm}, \varepsilon_{452}=2.66 \times 10^{3} \mathrm{~L} \cdot \mathrm{mol}-1 \cdot \mathrm{cm}-1$; HPLC: (C18 Gravity, method $C) \mathrm{t}_{\mathrm{R}},(Z)=10.12$ min, $\mathrm{t}_{\mathrm{R}},(E)=11.66 \mathrm{~min} ; \mathrm{HRMS}(\mathrm{ESI}): \mathrm{m} / \mathrm{Z}$ calcd for $\mathrm{C}_{55} \mathrm{H}_{67} \mathrm{~N}_{8} \mathrm{O}_{12}$ $[\mathrm{M}+\mathrm{H}]^{+}:$1031.4873, found: $1031.4892 ; \mathrm{m} / \mathrm{Z}$ calcd for $\mathrm{C}_{55} \mathrm{H}_{66} \mathrm{~N}_{8} \mathrm{O}_{12} \mathrm{Na}[\mathrm{M}+\mathrm{Na}]^{+}, 1053.4692$, found: 1053.4708 .

cyclo-[(2S,4E,8S)Hdn-Dab(Mtdps)-D-NMe-Trp- $\beta$ Tyr] (optojasp-6):

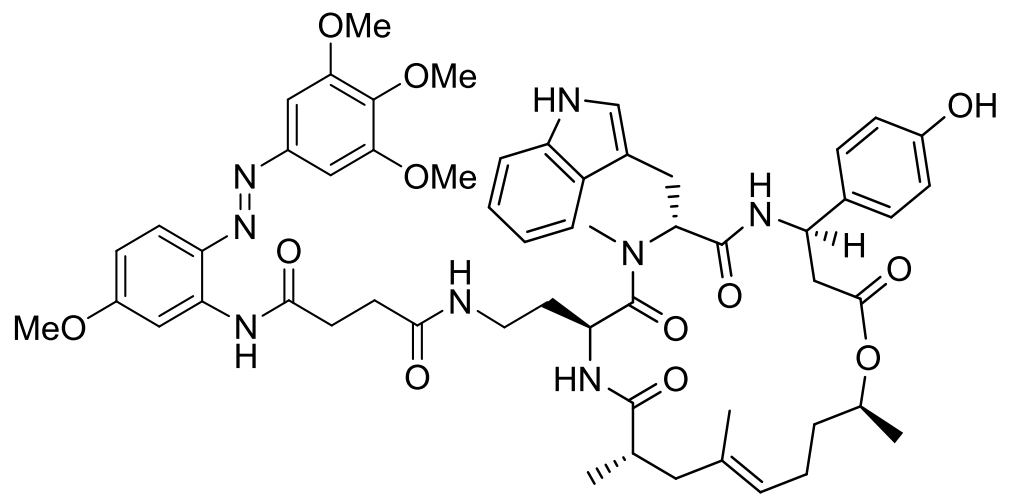

Boc-protected compound $9 \mathrm{~b}(10.0 \mathrm{mg}, 11.1 \mu \mathrm{mol}, 1.0$ equiv. $)$ was treated according to the procedure described for the synthesis of optojasp-1 with $\mathrm{HCl}$ to afford crude acid $\mathbf{1 0 b}$. LC- 
MS (ESI): $t_{R}=7.65$ min $(\mathrm{C} 18$ Gravity, method $B), \mathrm{m} / \mathrm{Z}$ calcd for $\mathrm{C}_{45} \mathrm{H}_{68} \mathrm{~N}_{5} \mathrm{O}_{6}[\mathrm{M}+\mathrm{H}]^{+}: 802.5$, found: 803.1 .

Then the crude product was treated with Azo-2 (4.6 mg, $11.1 \mu \mathrm{mol}, 1.0$ equiv.), HATU (10.1 mg, $26.6 \mu \mathrm{mol}, 2.4$ equiv.) and $N, N$-diisopropylethylamine (15.1 $\mu 1,88.7 \mu \mathrm{mol}$, 8.0 equiv.). Finally the residue was treated with hydrogen fluoride pyridine to provide optojasp-6 $(6.7 \mathrm{mg}, 59 \%)$ as an orange solid after silica-gel chromatography (1:1 $\mathrm{CH}_{2} \mathrm{Cl}_{2}$ /acetone). $\mathrm{R}_{\mathrm{f}}=0.22\left(1: 1 \mathrm{CH}_{2} \mathrm{Cl}_{2}\right.$ /acetone $) ;[\alpha]_{D}^{25.4}=+23.0\left(c=1.0\right.$ in $\left.\mathrm{CHCl}_{3}\right) ;{ }^{1} \mathrm{H}-$ NMR, $E$-isomer: (600 MHz, DMSO-d ${ }_{6}$ ): $\delta=10.71$ (br. s., 1H), 10.28 (s, 1H), 9.38 (br. s., $1 \mathrm{H}), 8.52(\mathrm{~d}, J=8.8 \mathrm{~Hz}, 1 \mathrm{H}), 8.01(\mathrm{~d}, J=2.6 \mathrm{~Hz}, 1 \mathrm{H}), 7.77(\mathrm{~d}, J=8.6 \mathrm{~Hz}, 1 \mathrm{H}), 7.72(\mathrm{~d}, J=$ $9.0 \mathrm{~Hz}, 1 \mathrm{H}), 7.65(\mathrm{t}, J=4.4 \mathrm{~Hz}, 1 \mathrm{H}), 7.61(\mathrm{~d}, J=7.9 \mathrm{~Hz}, 1 \mathrm{H}), 7.36(\mathrm{~s}, 2 \mathrm{H}), 7.23$ (d, $J=7.3$ $\mathrm{Hz}, 1 \mathrm{H}), 7.04$ (d, $J=8.4 \mathrm{~Hz}, 2 \mathrm{H}), 7.00$ (t, $J=7.5 \mathrm{~Hz}, 1 \mathrm{H}), 6.94-6.90$ (m, 2H), 6.76 (dd, $J=$ 2.6, $9.0 \mathrm{~Hz}, 1 \mathrm{H}), 6.66(\mathrm{~d}, J=8.4 \mathrm{~Hz}, 2 \mathrm{H}), 5.42(\mathrm{dd}, J=6.1,9.8 \mathrm{~Hz}, 1 \mathrm{H}), 5.15(\mathrm{ddd}, J=2.6$, 8.8, 11.2 Hz, 1H), $4.92(\mathrm{t}, J=6.8 \mathrm{~Hz}, 1 \mathrm{H}), 4.71-4.63(\mathrm{~m}, 2 \mathrm{H}), 3.87(\mathrm{~s}, 6 \mathrm{H}), 3.80(\mathrm{~s}, 3 \mathrm{H})$, $3.74(\mathrm{~s}, 3 \mathrm{H}), 3.00(\mathrm{~s}, 3 \mathrm{H}), 2.97-2.79(\mathrm{~m}, 4 \mathrm{H}), 2.75-2.67(\mathrm{~m}, 3 \mathrm{H}), 2.65(\mathrm{dd}, J=11.2,15.0 \mathrm{~Hz}$, $1 \mathrm{H}), 2.56(\mathrm{dd}, J=3.1,15.0 \mathrm{~Hz}, 1 \mathrm{H}), 2.45-2.42(\mathrm{~m}, 2 \mathrm{H}), 2.14(\mathrm{dd}, J=11.7,14.1 \mathrm{~Hz}, 1 \mathrm{H})$, 1.88-1.76 (m, 2H), 1.73 (d, $J=14.1 \mathrm{~Hz}, 1 \mathrm{H}), 1.46$ (s, 3H), 1.53-1.42 (m, 2H), 1.41-1.32 (m, $2 \mathrm{H}), 1.12(\mathrm{~d}, J=6.4 \mathrm{~Hz}, 3 \mathrm{H}), 0.91(\mathrm{~d}, J=6.6 \mathrm{~Hz}, 3 \mathrm{H}) ;{ }^{13} \mathrm{C}-\mathrm{NMR}$ : E-isomer $(126 \mathrm{MHz}$, DMSO- $\mathrm{d}_{6}$ ): $\delta=175.2,172.2,171.8,171.5,170.7,170.1,163.0,156.7,153.7,148.6,140.3$, $139.3,136.6,134.9,133.6,133.3,127.5,127.4,123.8,123.6,121.3,119.0,118.6,118.6$, 115.5, 111.6, 110.5, 110.0, 106.1, 101.1, 71.2, 60.7, 56.5, 56.0, 55.3, 49.4, 46.6, 43.2, 41.9, $38.2,35.7,35.3,32.6,30.9,30.8,29.5,26.0,24.0,20.0,19.9,17.2$; IR: $\tilde{v}_{\max }=3731,3626$, 3595, 2969, 2901, 1666, 1511, 1231, 1053, 671, 652; UV-VIS: $\lambda_{\max }\left(\mathrm{CH}_{3} \mathrm{CN}\right)=E$-isomer.: $391 \mathrm{~nm}, \varepsilon_{391}=17.0 \times 10^{3} \mathrm{~L} \cdot \mathrm{mol}^{-1} \cdot \mathrm{cm}^{-1}, Z$-isomer: $453 \mathrm{~nm}, \varepsilon_{453}=2.60 \times 10^{3} \mathrm{~L} \cdot \mathrm{mol}^{-1} \cdot \mathrm{cm}^{-1}$; HPLC: $(C 18$ Gravity, method $C) \mathrm{t}_{\mathrm{R}},(Z)=10.13 \mathrm{~min}, \mathrm{t}_{\mathrm{R}},(E)=11.35 \mathrm{~min}$; HRMS (ESI): $\mathrm{m} / \mathrm{Z}$ calcd for $\mathrm{C}_{56} \mathrm{H}_{69} \mathrm{~N}_{8} \mathrm{O}_{12}[\mathrm{M}+\mathrm{H}]^{+}:$1045.5031, found: $1045.5047 ; \mathrm{m} / \mathrm{Z}$ calcd for $\mathrm{C}_{56} \mathrm{H}_{68} \mathrm{~N}_{8} \mathrm{O}_{12} \mathrm{Na}$ $[\mathrm{M}+\mathrm{Na}]^{+}, 1067.4850$, found: 1067.4862 . 


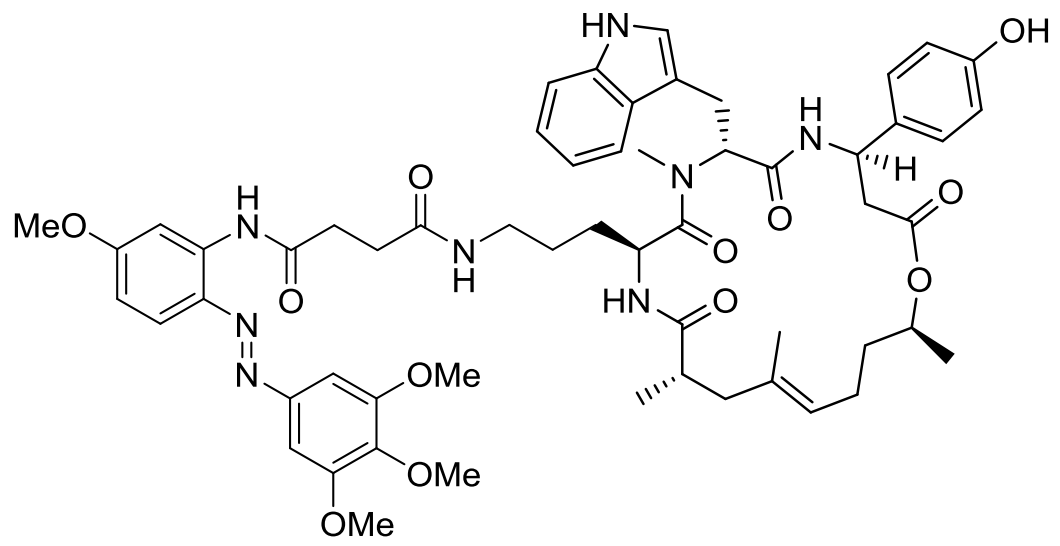

Boc-protected compound 9c $(10.0 \mathrm{mg}, 10.9 \mu \mathrm{mol}, 1.0$ equiv.) was treated according to the procedure described for the synthesis of optojasp-1 with $\mathrm{HCl}$ to afford crude acid 10c. LCMS (ESI): $t_{R}=5.44$ min (C18 Gravity, method $C$ ), $\mathrm{m} / \mathrm{Z}$ calcd for $\mathrm{C}_{46} \mathrm{H}_{70} \mathrm{~N}_{5} \mathrm{O}_{6}[\mathrm{M}+\mathrm{H}]^{+}: 816.5$, found: 816.7 .

Then the crude product was treated with Azo-2 (4.6 mg, $10.9 \mu \mathrm{mol}, 1.0$ equiv.), HATU (10.0 mg, $26.2 \mu \mathrm{mol}, 2.4$ equiv.) and $N, N$-diisopropylethylamine (14.9 $\mu 1,87.3 \mu \mathrm{mol}$, 8.0 equiv.). Finally the residue was treated with hydrogen fluoride pyridine to provide optojasp-7 $(6.5 \mathrm{mg}, 58 \%)$ as an orange solid after silica-gel chromatography (1:1 $\mathrm{CH}_{2} \mathrm{Cl}_{2}$ /acetone). $\mathrm{R}_{\mathrm{f}}=0.22\left(1: 1 \mathrm{CH}_{2} \mathrm{Cl}_{2}\right.$ /acetone $\left.) ; \alpha\right]_{D}^{25.3}=+26.8\left(c=1.0\right.$ in $\left.\mathrm{CHCl}_{3}\right) ;{ }^{1} \mathrm{H}-$ NMR, E-isomer: (500 MHz, DMSO-d $\left.{ }_{6}\right): \delta=10.74$ (d, $\left.J=1.8 \mathrm{~Hz}, 1 \mathrm{H}\right), 10.27$ (s, 1H), 9.30 (s, $1 \mathrm{H}), 8.61(\mathrm{~d}, J=8.9 \mathrm{~Hz}, 1 \mathrm{H}), 8.02(\mathrm{~d}, J=2.7 \mathrm{~Hz}, 1 \mathrm{H}), 7.75(\mathrm{~d}, J=9.2 \mathrm{~Hz}, 1 \mathrm{H}), 7.70(\mathrm{~d}, J=$ $9.2 \mathrm{~Hz}, 1 \mathrm{H}), 7.68$ (t, $J=5.2 \mathrm{~Hz}, 1 \mathrm{H}), 7.65$ (d, $J=7.9 \mathrm{~Hz}, 1 \mathrm{H}), 7.39$ (s, 2H), 7.27 (d, $J=7.9$ Hz, 1H), $7.10(\mathrm{~d}, J=8.9 \mathrm{~Hz}, 2 \mathrm{H}), 7.03-6.98(\mathrm{~m}, 2 \mathrm{H}), 6.94(\mathrm{t}, J=7.0 \mathrm{~Hz}, 1 \mathrm{H}), 6.79$ (dd, $J=$ 2.7, $9.2 \mathrm{~Hz}, 1 \mathrm{H}), 6.69(\mathrm{~d}, J=8.5 \mathrm{~Hz}, 2 \mathrm{H}), 5.49(\mathrm{dd}, J=5.5,10.7 \mathrm{~Hz}, 1 \mathrm{H}), 5.18(\mathrm{ddd}, J=2.9$, 8.8, 11.2 Hz, 1H), $4.92(\mathrm{t}, J=6.6 \mathrm{~Hz}, 1 \mathrm{H}), 4.68(\mathrm{sxt}, J=6.3 \mathrm{~Hz}, 1 \mathrm{H}), 4.56$ (dt, $J=5.0,8.5$ $\mathrm{Hz}, 1 \mathrm{H}), 3.90(\mathrm{~s}, 6 \mathrm{H}), 3.83(\mathrm{~s}, 3 \mathrm{H}), 3.76(\mathrm{~s}, 3 \mathrm{H}), 3.01(\mathrm{~s}, 3 \mathrm{H}), 3.05-2.89(\mathrm{~m}, 3 \mathrm{H}), 2.72(\mathrm{t}, J=$ $7.0 \mathrm{~Hz}, 2 \mathrm{H}), 2.78-2.66(\mathrm{~m}, 3 \mathrm{H}), 2.58(\mathrm{dd}, J=3.1,15.0 \mathrm{~Hz}, 1 \mathrm{H}), 2.43(\mathrm{t}, J=7.0 \mathrm{~Hz}, 2 \mathrm{H})$, 2.19-2.12 (m, $J=11.9,13.7 \mathrm{~Hz}, 1 \mathrm{H}), 1.84$ (tt, $J=7.6,15.3 \mathrm{~Hz}, 2 \mathrm{H}), 1.73$ (d, $J=15.0 \mathrm{~Hz}$, $1 \mathrm{H}), 1.48(\mathrm{~s}, 3 \mathrm{H}), 1.54-1.44(\mathrm{~m}, 1 \mathrm{H}), 1.42-1.34(\mathrm{~m}, 1 \mathrm{H}), 1.15(\mathrm{~d}, J=6.1 \mathrm{~Hz}, 3 \mathrm{H}), 1.00$ $0.93(\mathrm{~m}, 2 \mathrm{H}), 0.91(\mathrm{~d}, J=6.7 \mathrm{~Hz}, 3 \mathrm{H}), 0.87-0.79(\mathrm{~m}, 2 \mathrm{H}) ;{ }^{13} \mathrm{C}-\mathrm{NMR}$ : $E$-isomer $(126 \mathrm{MHz}$, DMSO- $\left.\mathrm{d}_{6}\right): \delta=174.9,172.6,171.8,171.4,170.8,170.4,163.0,156.7,153.7,148.6,140.3$, $139.3,136.5,134.9,133.6,133.5,127.5,127.4,123.8,123.6,121.3,119.1,118.6,118.5$, 115.5, 111.6, 110.4, 110.0, 106.1, 101.1, 71.3, 60.7, 56.5, 56.0, 55.1, 49.4, 48.0, 43.1, 42.1, $38.7,38.2,35.3,32.7,31.0,30.8,29.5,25.9,24.1,22.6,20.1,20.0,17.3 ;$ IR: $\tilde{v}_{\max }=3730$, 
3703, 3626, 3594, 2970, 2901, 1670, 1512, 1231, 1053, 670, 652; UV-VIS: $\lambda_{\max }\left(\mathrm{CH}_{3} \mathrm{CN}\right)=$ $E$-isomer.: $390 \mathrm{~nm}, \varepsilon_{390}=16.7 \times 10^{3} \mathrm{~L} \cdot \mathrm{mol}^{-1} \cdot \mathrm{cm}^{-1}, Z$-isomer: $453 \mathrm{~nm}, \varepsilon_{453}=2.46 \times 10^{3}$ $\mathrm{L} \cdot \mathrm{mol}^{-1} \cdot \mathrm{cm}^{-1}$; HPLC: $(\mathrm{C} 18$ Gravity, $\operatorname{method} C) \mathrm{t}_{\mathrm{R}},(Z)=10.13 \mathrm{~min}, \mathrm{t}_{\mathrm{R}},(E)=11.24 \mathrm{~min}$; HRMS (ESI): $\mathrm{m} / \mathrm{Z}$ calcd for $\mathrm{C}_{57} \mathrm{H}_{71} \mathrm{~N}_{8} \mathrm{O}_{12}[\mathrm{M}+\mathrm{H}]^{+}:$1059.5186, found: $1059.5190 ; \mathrm{m} / \mathrm{Z}$ calcd for $\mathrm{C}_{57} \mathrm{H}_{70} \mathrm{~N}_{8} \mathrm{O}_{12} \mathrm{Na}[\mathrm{M}+\mathrm{Na}]^{+}, 1081.5005$, found: 1081.5005 .

cyclo-[(2S,4E,8S)Hdn-Lys(Mtdps)-D-NMe-Trp- $\beta$ Tyr] (optojasp-8):

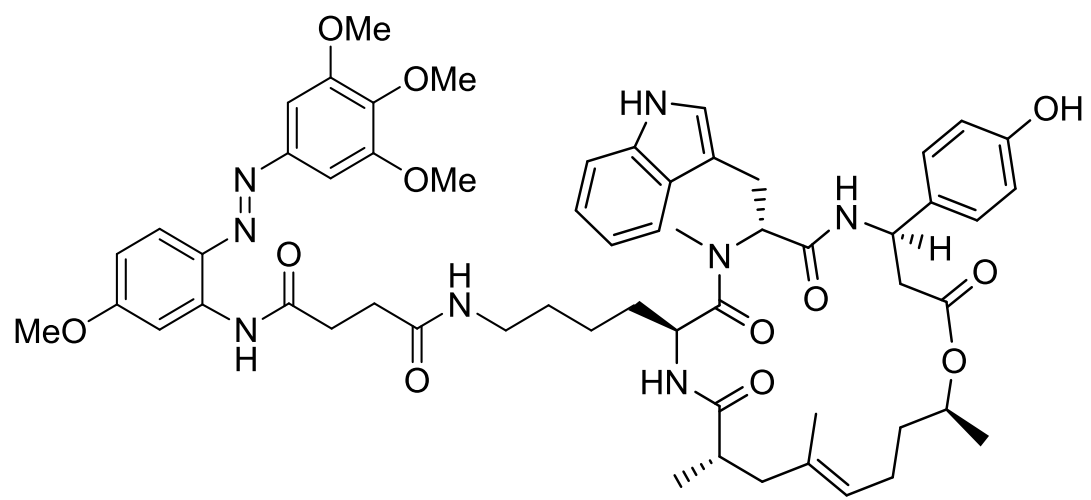

Boc-protected compound 9d (19.0 mg, $20.4 \mu \mathrm{mol}, 1.0$ equiv.) was treated according to the procedure described for the synthesis of optojasp-1 with $\mathrm{HCl}$ to afford crude acid 10d. LCMS (ESI): $t_{R}=5.67$ min $(\mathrm{C} 18$ Gravity, method $C), \mathrm{m} / \mathrm{Z}$ calcd for $\mathrm{C}_{47} \mathrm{H}_{72} \mathrm{~N}_{5} \mathrm{O}_{6}[\mathrm{M}+\mathrm{H}]^{+}: 830.5$, found: 831.2 .

Then the crude product was treated with Azo-2 (8.5 mg, $20.4 \mu \mathrm{mol}, 1.0$ equiv.), HATU (18.6 mg, $49.0 \mu \mathrm{mol}, 2.4$ equiv.) and $N, N$-diisopropylethylamine (27.8 $\mu 1,163 \mu \mathrm{mol}$, 8.0 equiv.). Finally the residue was treated with hydrogen fluoride pyridine to provide optojasp-8 (17.0 mg, $81 \%)$ as an orange solid after silica-gel chromatography (1:1 $\mathrm{CH}_{2} \mathrm{Cl}_{2}$ /acetone). $\mathrm{R}_{\mathrm{f}}=0.21\left(1: 1 \mathrm{CH}_{2} \mathrm{Cl}_{2}\right.$ /acetone $) ;[\alpha]_{D}^{25.2}=+31.6\left(c=0.8\right.$ in $\left.\mathrm{CHCl}_{3}\right) ;{ }^{1} \mathrm{H}-$ NMR, E-isomer: (600 MHz, DMSO-d $\left.)_{6}\right): \delta=10.78$ (br. s., 1H), 10.28 (s, 1H), 9.31 (s, 1H), $8.63(\mathrm{~d}, J=8.4 \mathrm{~Hz}, 1 \mathrm{H}), 8.04(\mathrm{~d}, J=1.8 \mathrm{~Hz}, 1 \mathrm{H}), 7.84$ (t, $J=5.4 \mathrm{~Hz}, 1 \mathrm{H}), 7.74(\mathrm{~d}, J=9.2 \mathrm{~Hz}$, 1H), $7.67(\mathrm{~d}, J=8.6 \mathrm{~Hz}, 1 \mathrm{H}), 7.65(\mathrm{~d}, J=7.9 \mathrm{~Hz}, 1 \mathrm{H}), 7.39$ (s, 2H), 7.27 (d, $J=8.1 \mathrm{~Hz}, 1 \mathrm{H})$, $7.12(\mathrm{~d}, J=8.4 \mathrm{~Hz}, 2 \mathrm{H}), 7.03(\mathrm{~s}, 1 \mathrm{H}), 7.00(\mathrm{t}, J=7.4 \mathrm{~Hz}, 1 \mathrm{H}), 6.93(\mathrm{t}, J=7.5 \mathrm{~Hz}, 1 \mathrm{H}), 6.78$ $(\mathrm{dd}, J=2.0,9.2 \mathrm{~Hz}, 1 \mathrm{H}), 6.70(\mathrm{~d}, J=8.3 \mathrm{~Hz}, 2 \mathrm{H}), 5.50(\mathrm{dd}, J=4.7,11.3 \mathrm{~Hz}, 1 \mathrm{H}), 5.18$ (ddd, $J=2.4,8.8,11.0 \mathrm{~Hz}, 1 \mathrm{H}), 4.92(\mathrm{t}, J=6.6 \mathrm{~Hz}, 1 \mathrm{H}), 4.67(\mathrm{sxt}, J=6.2 \mathrm{~Hz}, 1 \mathrm{H}), 4.57-4.50$ (m, $1 \mathrm{H}), 3.90(\mathrm{~s}, 6 \mathrm{H}), 3.83(\mathrm{~s}, 3 \mathrm{H}), 3.75(\mathrm{~s}, 3 \mathrm{H}), 3.01(\mathrm{~s}, 3 \mathrm{H}), 3.05-2.98(\mathrm{~m}, 1 \mathrm{H}), 2.92(\mathrm{dd}, J=$ 5.0, $14.9 \mathrm{~Hz}, 1 \mathrm{H}), 2.84(\mathrm{td}, J=6.6,12.9 \mathrm{~Hz}, 1 \mathrm{H}), 2.79(\mathrm{td}, J=6.5,13.4 \mathrm{~Hz}, 1 \mathrm{H}), 2.74(\mathrm{t}, J=$ $6.8 \mathrm{~Hz}, 2 \mathrm{H}), 2.68(\mathrm{dd}, J=11.9,14.3 \mathrm{~Hz}, 1 \mathrm{H}), 2.63-2.55(\mathrm{~m}, 2 \mathrm{H}), 2.46(\mathrm{t}, J=6.8 \mathrm{~Hz}, 2 \mathrm{H})$, $2.16(\mathrm{dd}, J=11.6,14.3 \mathrm{~Hz}, 1 \mathrm{H}), 1.89-1.76(\mathrm{~m}, J=8.6 \mathrm{~Hz}, 2 \mathrm{H}), 1.72(\mathrm{~d}, J=14.7 \mathrm{~Hz}, 1 \mathrm{H})$, 
$1.48(\mathrm{~s}, 3 \mathrm{H}), 1.53-1.44(\mathrm{~m}, 1 \mathrm{H}), 1.41-1.34(\mathrm{~m}, 1 \mathrm{H}), 1.16(\mathrm{~d}, J=6.2 \mathrm{~Hz}, 3 \mathrm{H}), 1.11-1.02(\mathrm{~m}$, $2 \mathrm{H}), 0.91(\mathrm{~d}, J=6.6 \mathrm{~Hz}, 3 \mathrm{H}), 0.83-0.74(\mathrm{~m}, 3 \mathrm{H}), 0.69-0.62(\mathrm{~m}, 1 \mathrm{H}) ;{ }^{13} \mathrm{C}-\mathrm{NMR}: E$-isomer $\left(150 \mathrm{MHz} ;\right.$ DMSO-d $\left.\mathrm{d}_{6}\right): \delta=174.9,172.7,171.8,171.6,170.8,170.5,163.0,156.7,153.7$, $148.6,140.3,139.3,136.6,134.8,133.6,133.5,127.5,127.4,123.8,123.4,121.3,119.1$, 118.6, 118.5, 115.5, 111.6, 110.4, 110.0, 106.0, 101.1, 71.4, 60.7, 56.5, 56.0, 55.0, 49.5, 48.1, $42.9,42.1$, 38.8, 38.1, 35.3, 32.9, 31.0, 31.0, 30.9, 29.0, 26.0, 24.2, 22.5, 20.1, 19.9, 17.4; IR: $\tilde{v}_{\max }=3730,3704,3595,2970,2901,1668,1514,1234,1057,671$, 652; UV-VIS: $\lambda_{\max }$ $\left(\mathrm{CH}_{3} \mathrm{CN}\right)=E$-isomer.: $391 \mathrm{~nm}, \varepsilon_{391}=16.4 \mathrm{x} 10^{3} \mathrm{~L} \cdot \mathrm{mol}^{-1} \cdot \mathrm{cm}^{-1}, Z$-isomer: $452 \mathrm{~nm}, \varepsilon_{452}=2.27 \mathrm{x}$ $10^{3} \mathrm{~L} \cdot \mathrm{mol}^{-1} \cdot \mathrm{cm}^{-1}$; HPLC: (C18 Gravity, $\left.\operatorname{method} C\right) \mathrm{t}_{\mathrm{R}},(Z)=10.14 \mathrm{~min}, \mathrm{t}_{\mathrm{R}},(E)=11.36 \mathrm{~min}$; HRMS (ESI): $\mathrm{m} / \mathrm{Z}$ calcd for $\mathrm{C}_{58} \mathrm{H}_{73} \mathrm{~N}_{8} \mathrm{O}_{12}[\mathrm{M}+\mathrm{H}]^{+}: 1073.5343$, found: $1073.5355 ; \mathrm{m} / \mathrm{Z}$ calcd for $\mathrm{C}_{58} \mathrm{H}_{74} \mathrm{~N}_{8} \mathrm{O}_{12}[\mathrm{M}+2 \mathrm{H}]^{2+}$, 537.2708, found: 537.2709. 


\section{Supplementary Note 2: optojasp HPLC traces}
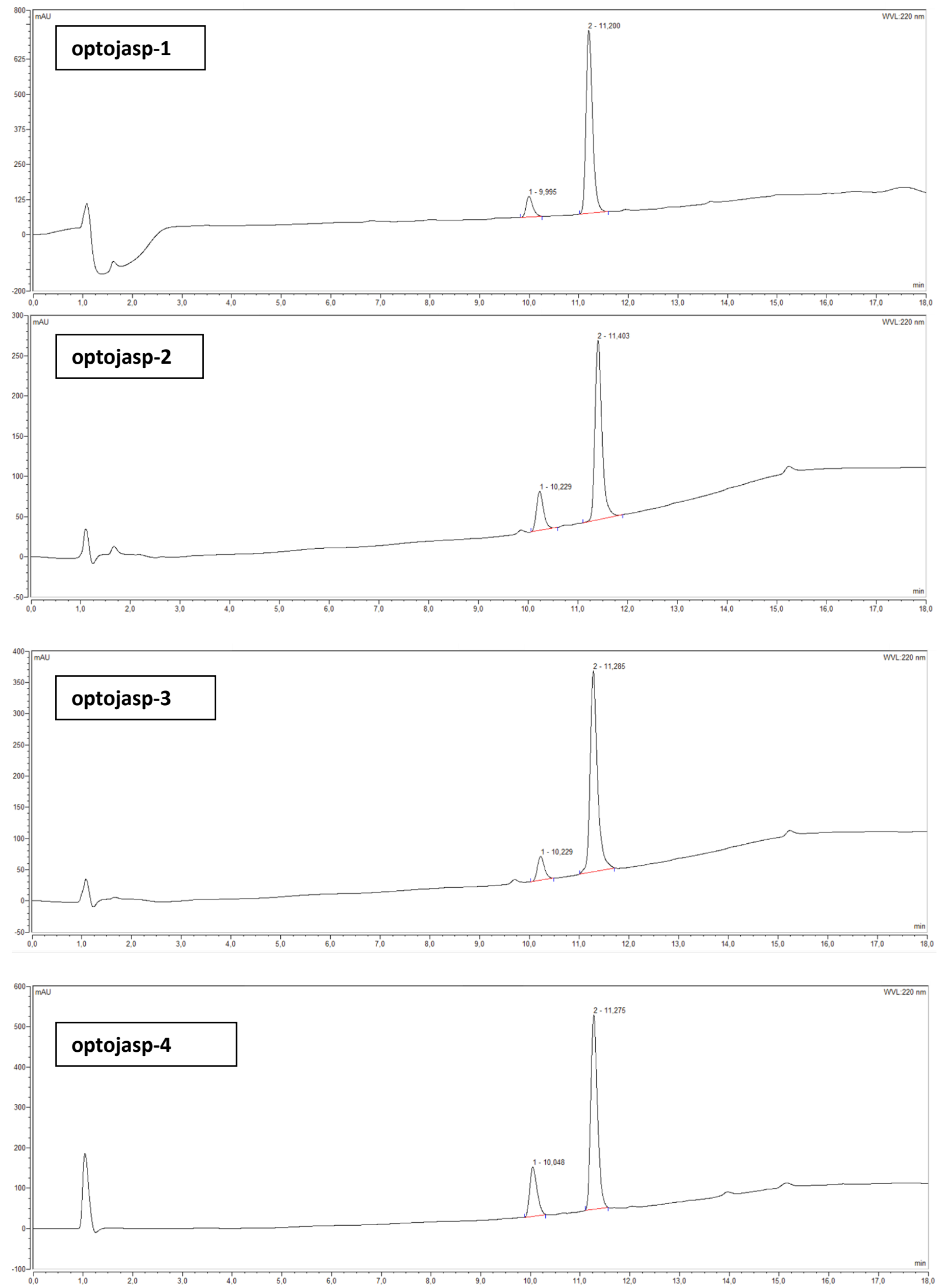

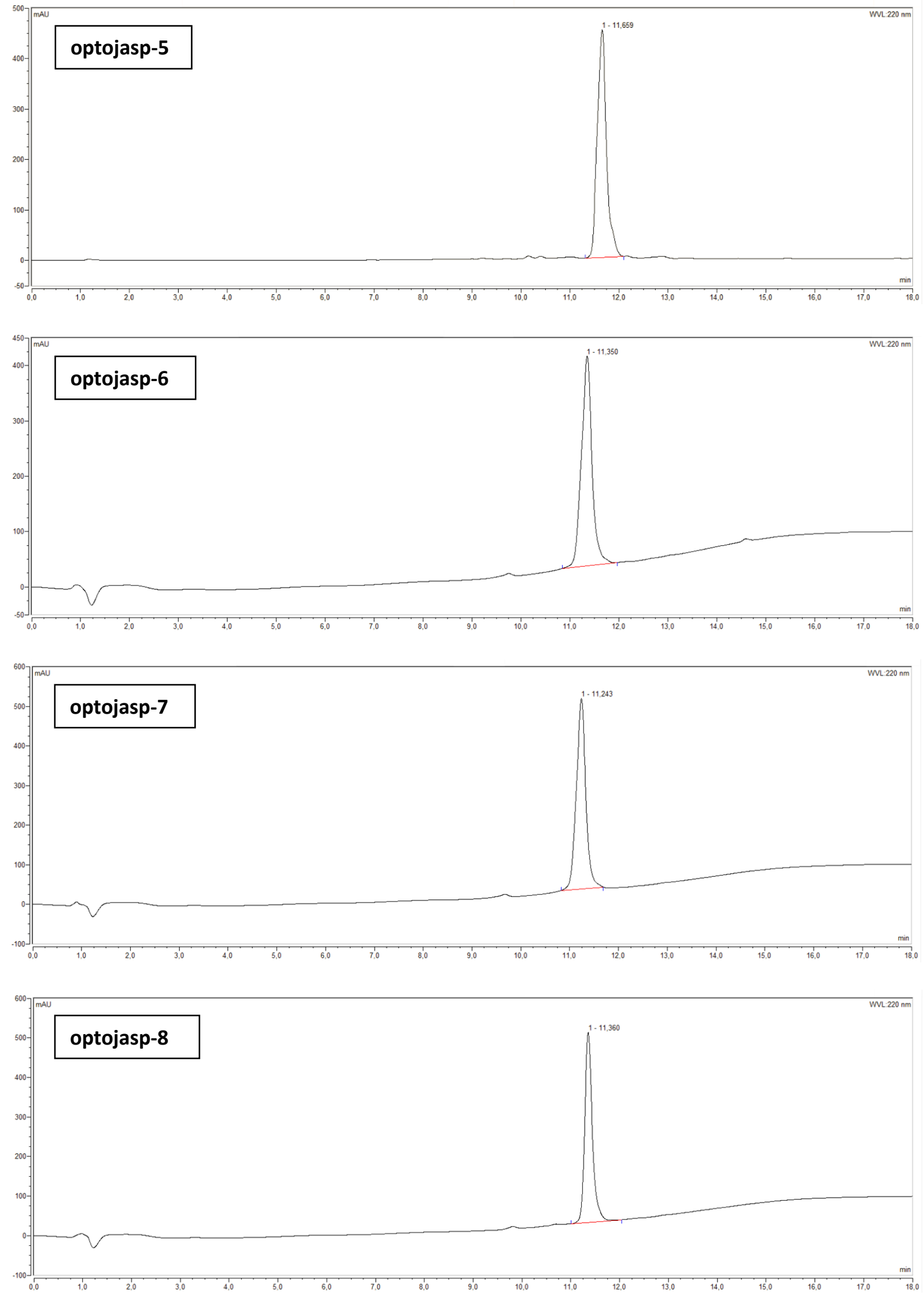

Figure S3: HPLC traces of optojasp 1-8. C18 Gravity. Gradient 30\% Acetonitrile in $\mathrm{H}_{2} \mathrm{O}$ over 10 Minutes to $100 \%$ Acetonitrile. optojasp 1-4 mixture of $E$ - and $Z$-Isomer. 


\section{$\underline{\text { Supplementary Note 3: optojasp }{ }^{1} \text { H-NMRs }}$}

optojasp-1, ${ }^{1}$ H-NMR (600 MHz, DMSO-d 6 ):

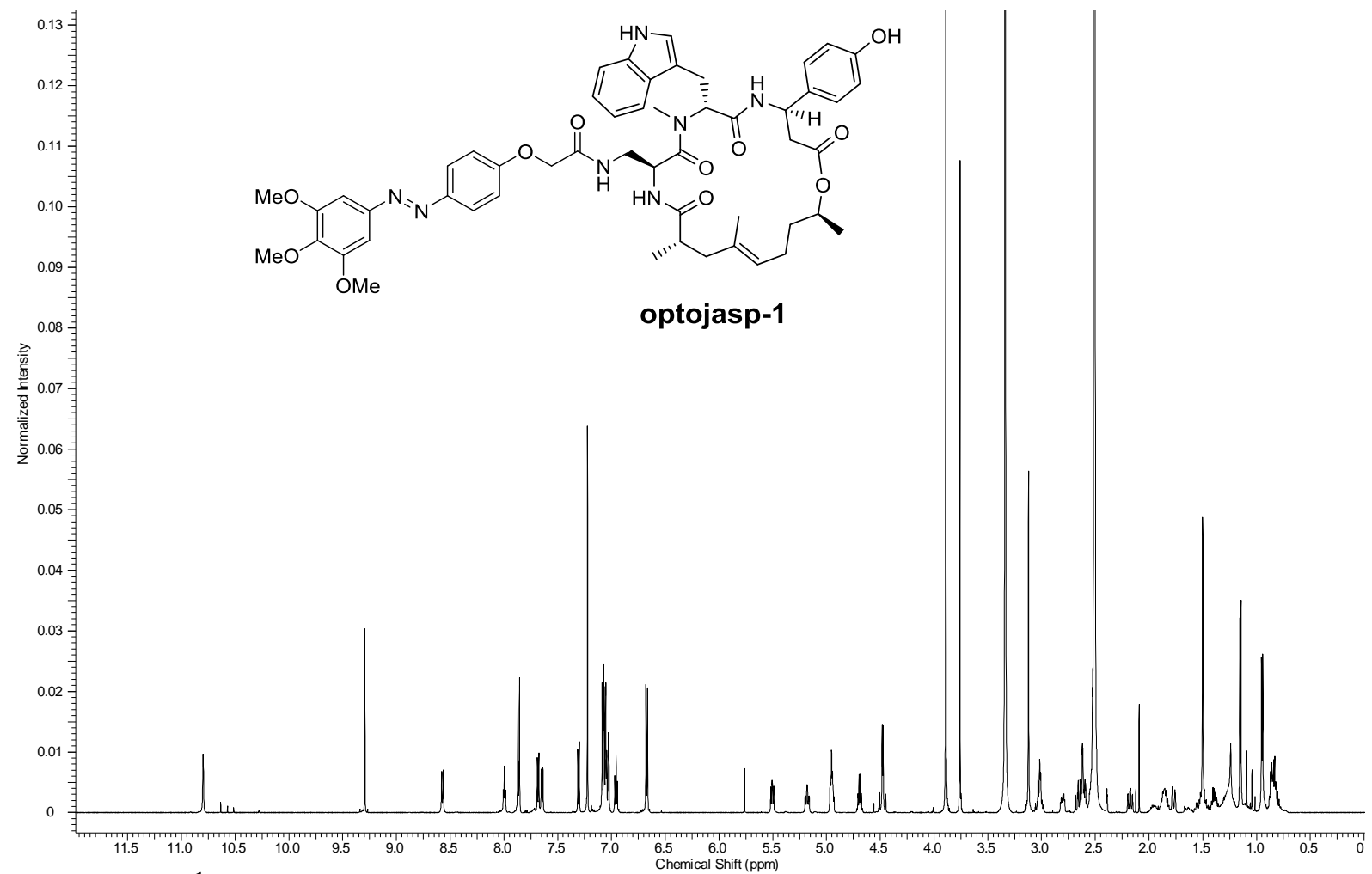

optojasp-2, ${ }^{1}$ H-NMR (600 MHz, DMSO-d 6 ):

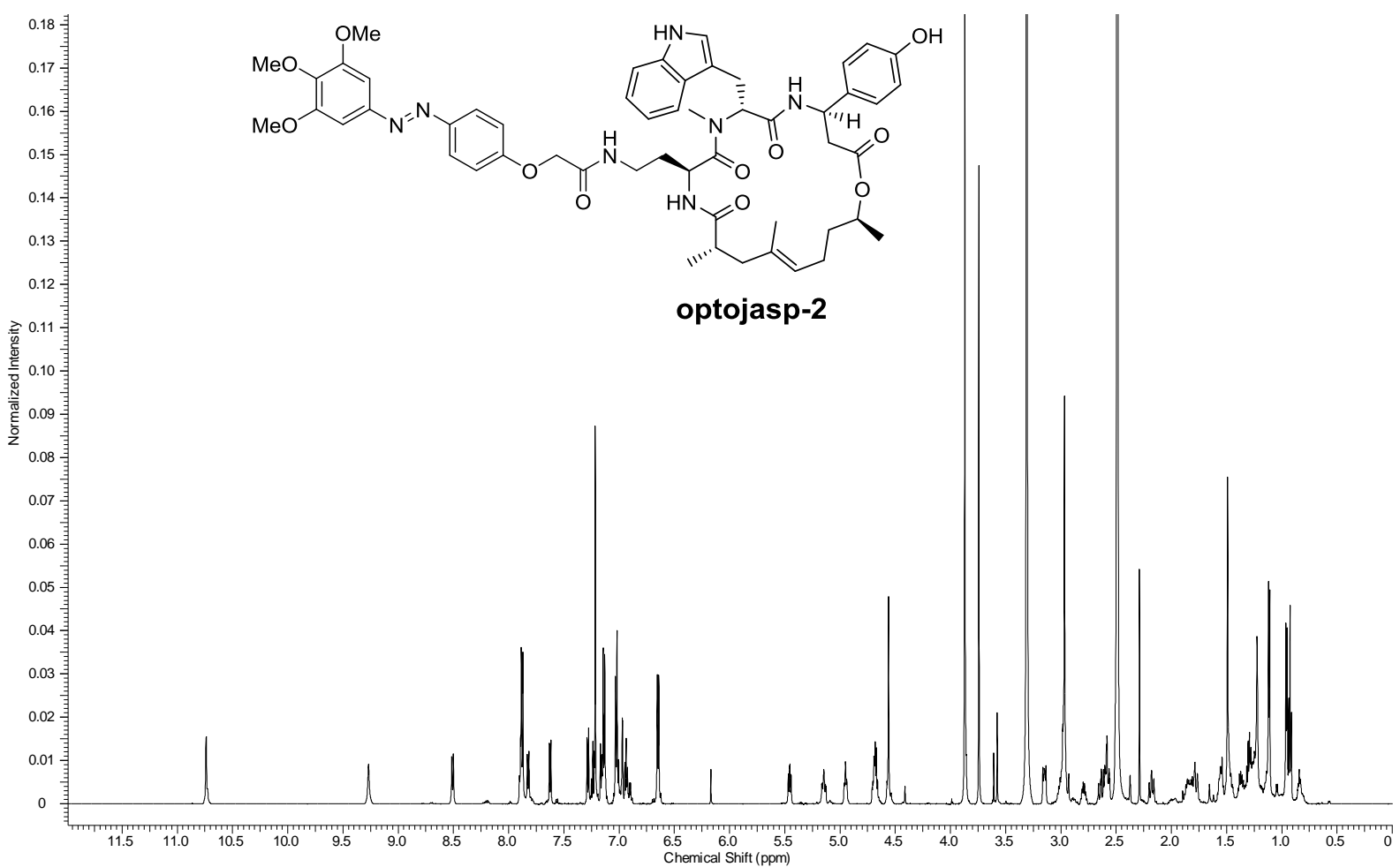


optojasp-3, ${ }^{1}$ H-NMR (600 MHz, DMSO-d 6 ):

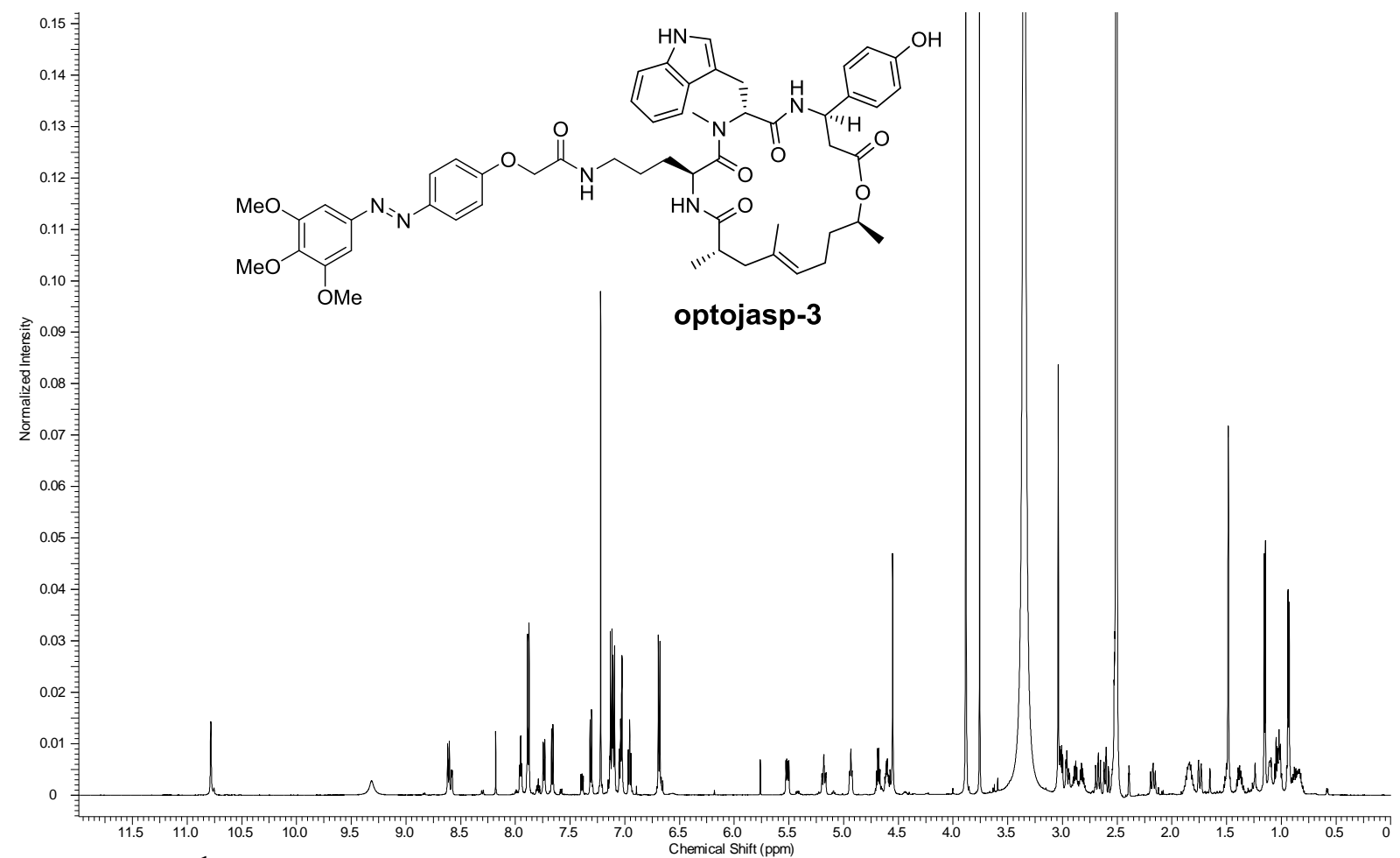

optojasp-4, ${ }^{1} \mathrm{H}-\mathrm{NMR}$ (500 MHz, DMSO-d 6 ):

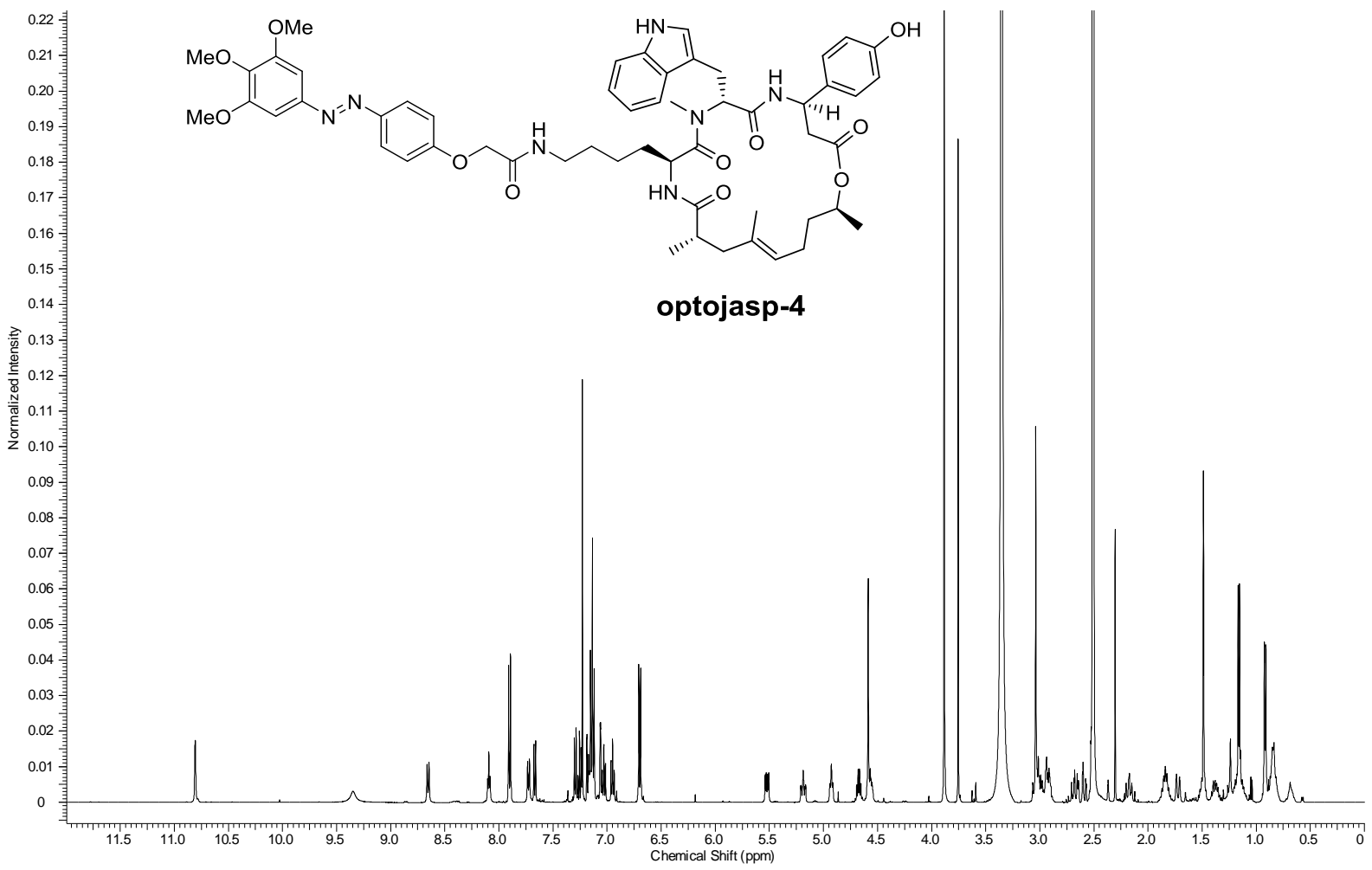


optojasp-5, ${ }^{1}$ H-NMR (600 MHz, DMSO-d ${ }_{6}$ ):

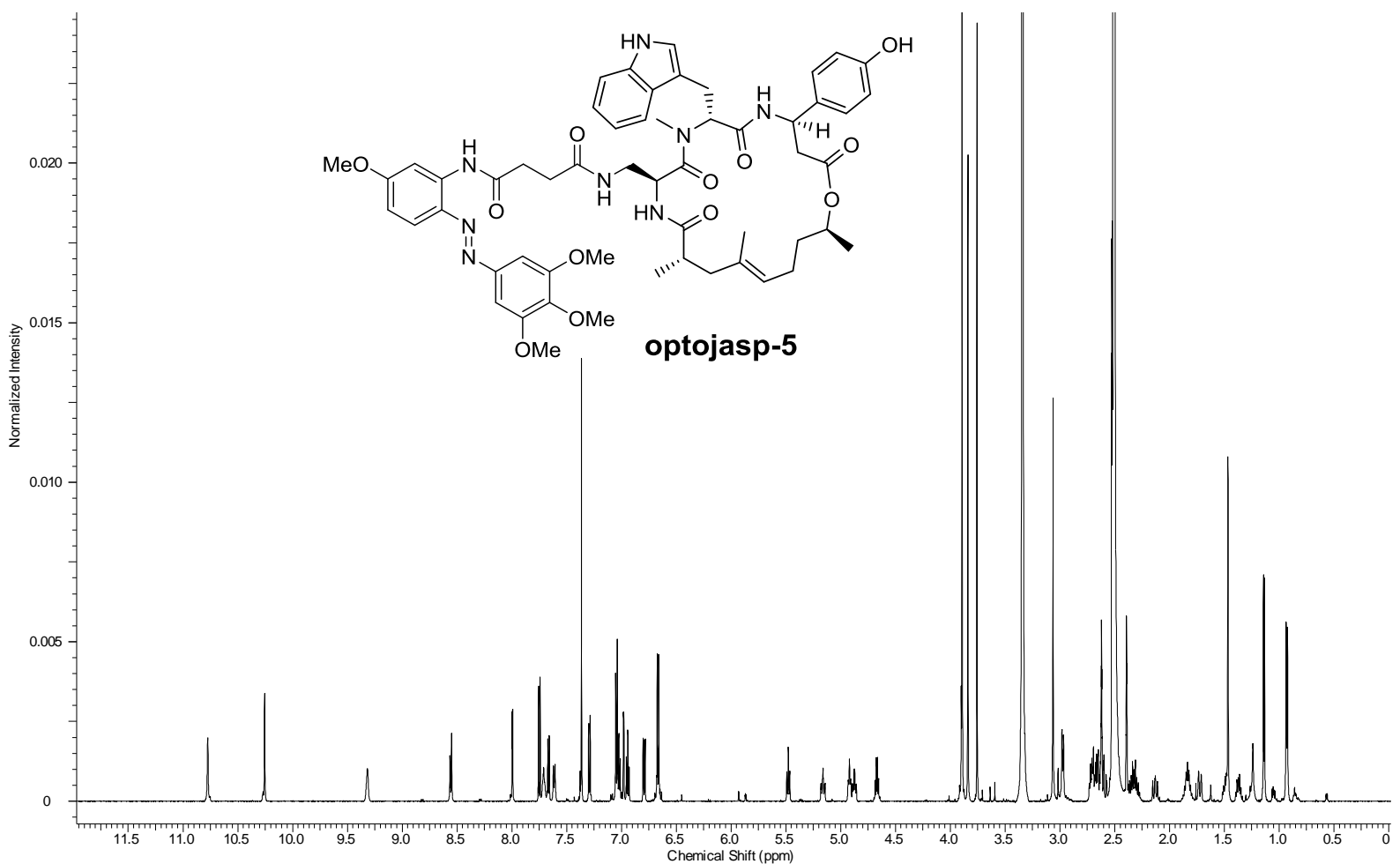

optojasp-6, ${ }^{1}$ H-NMR (600 MHz, DMSO-d ${ }_{6}$ ):

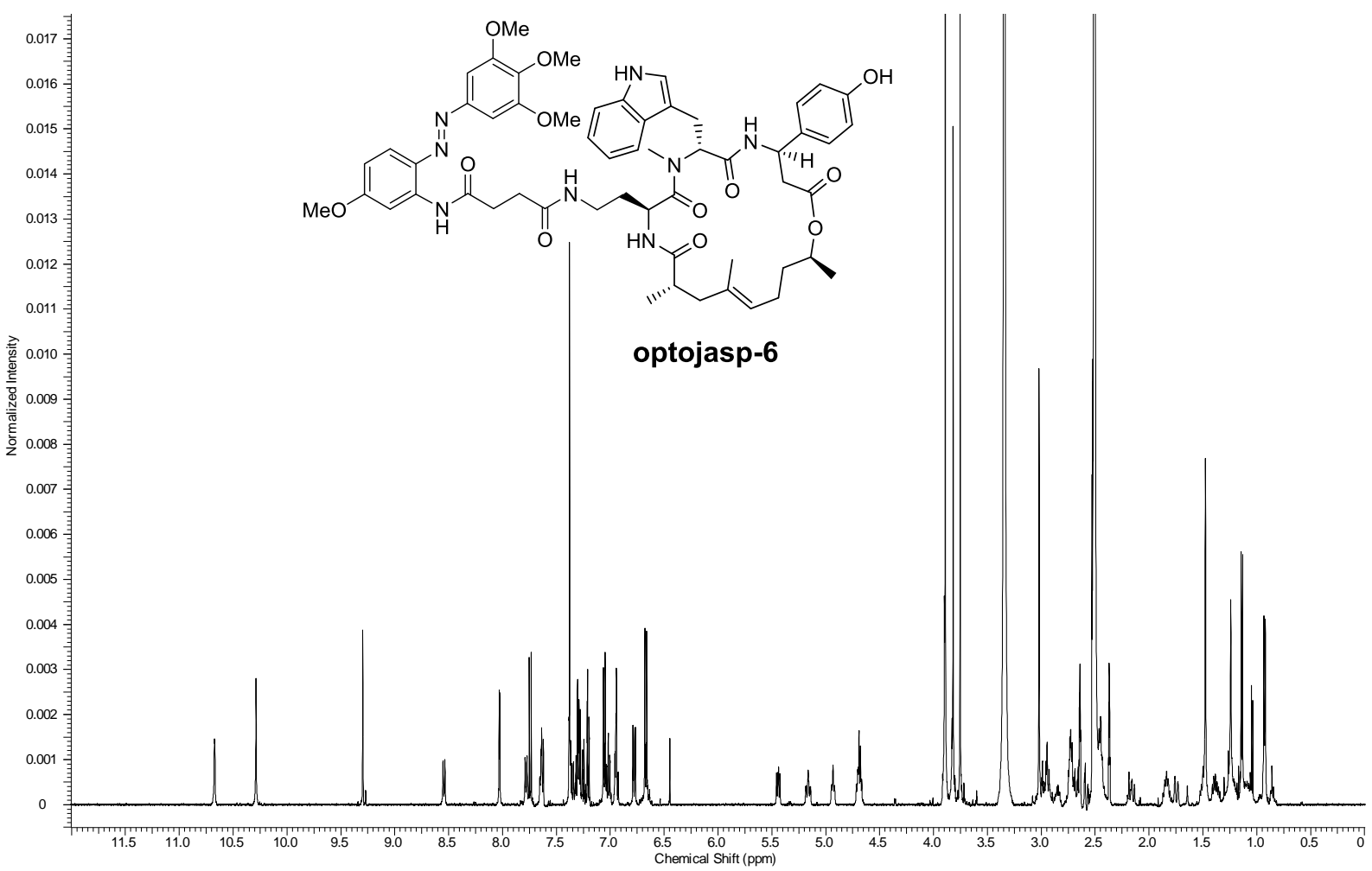


optojasp-7, ${ }^{1}$ H-NMR (500 MHz, DMSO-d 6 ):

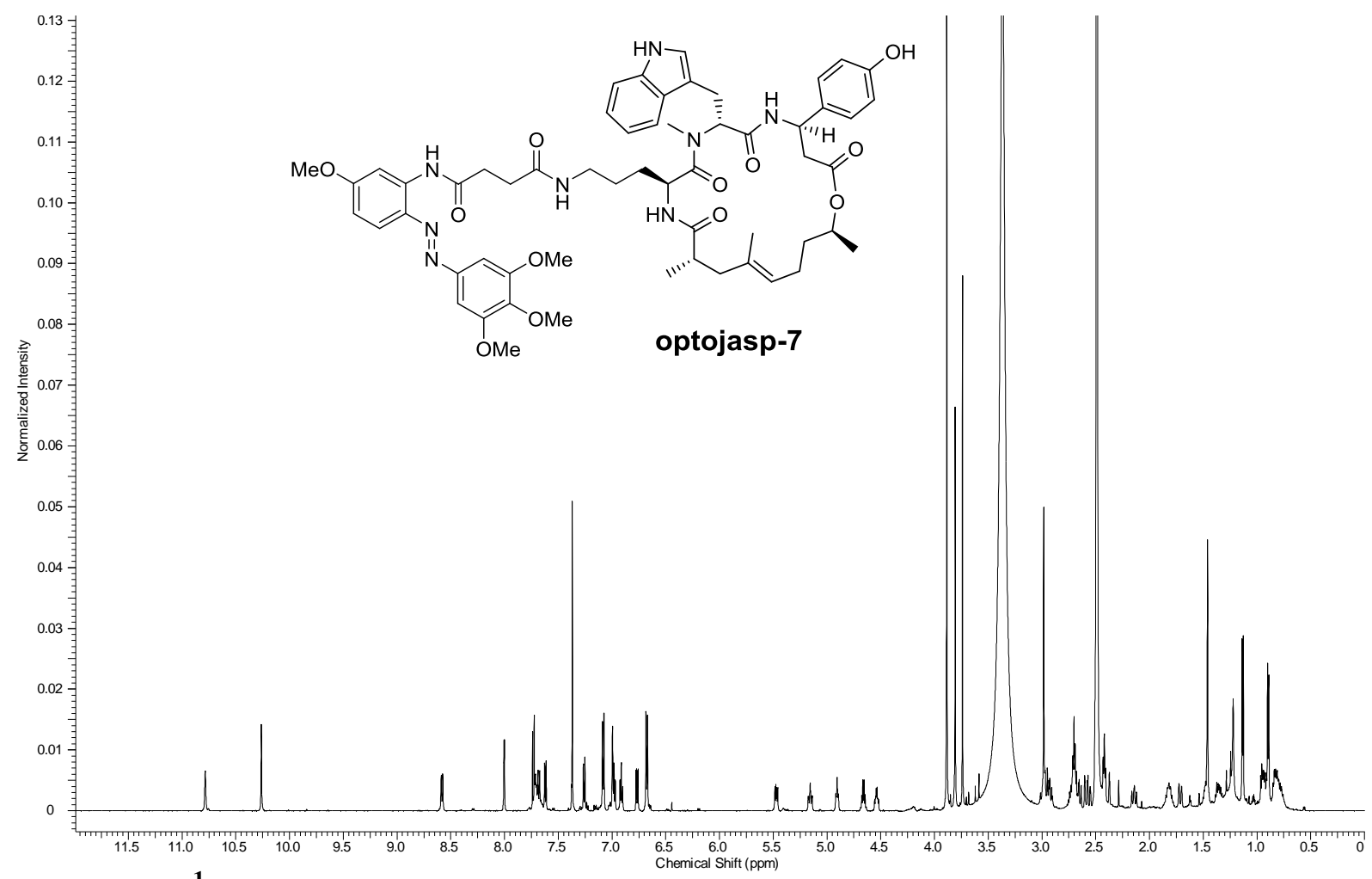

optojasp-8, ${ }^{1}$ H-NMR (600 MHz, DMSO-d ${ }_{6}$ ):

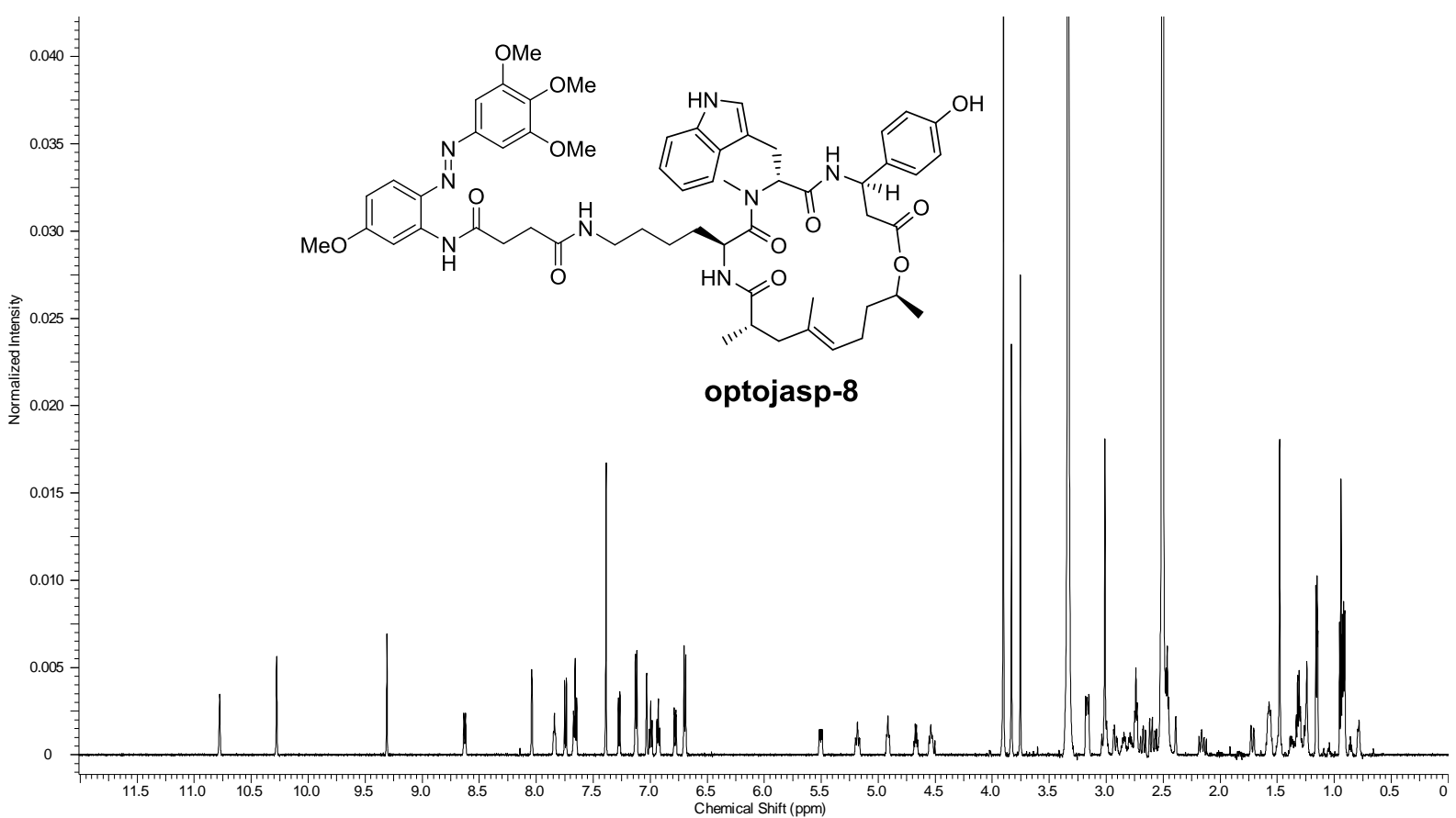




\section{Supplementary Note 4: optojasp E/Z-isomer UV-VIS spectra}
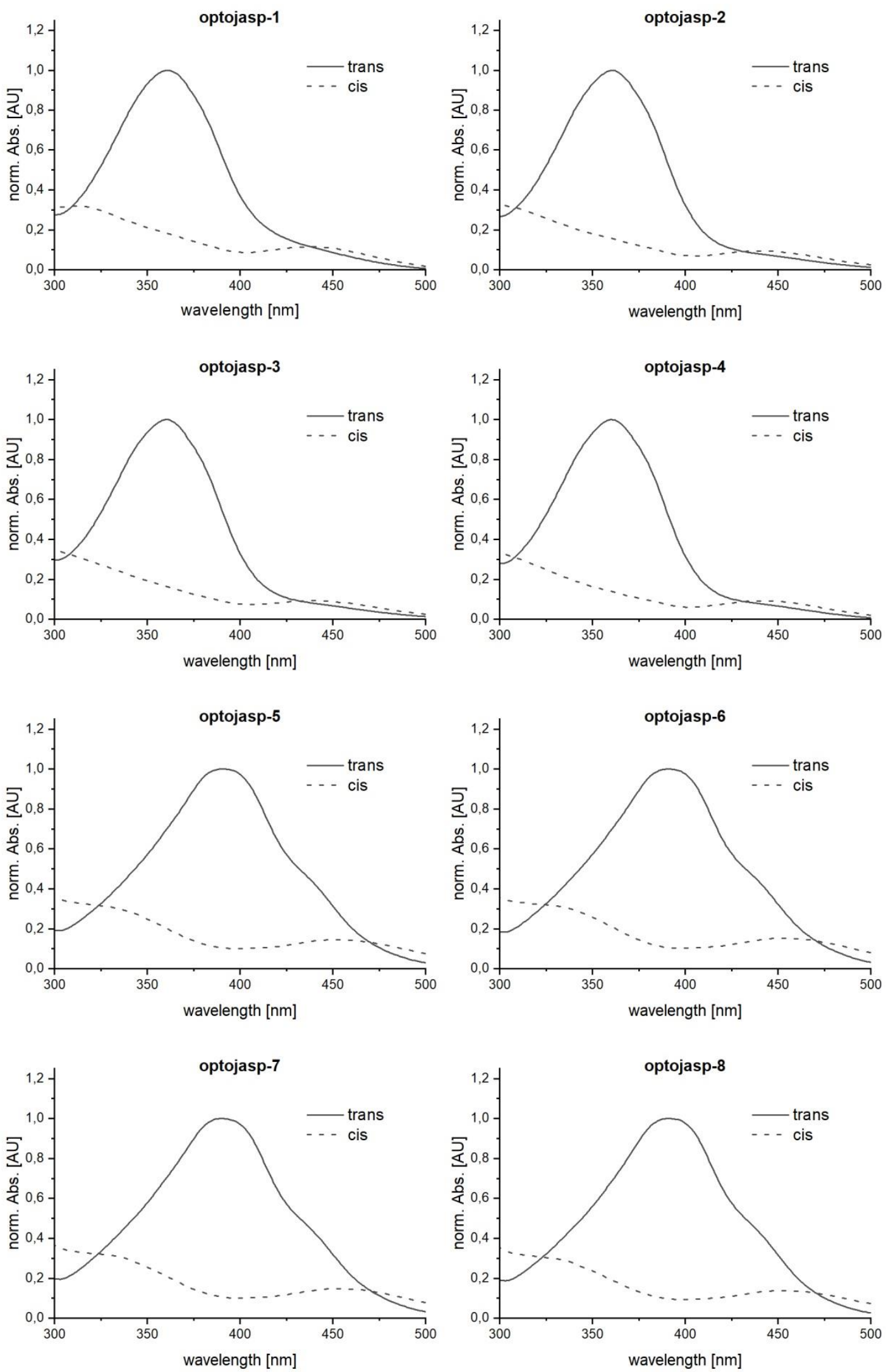

Figure S6: UV-VIS absorption spectra of optojasp 1-8 in acetonitrile. 


\section{Supplemental References}

(S1) Borowiak, M.; Nahaboo, W.; Reynders, M.; Nekolla, K.; Jalinot, P.; Hasserodt, J.; Rehberg, M.; Delattre, M.; Zahler, S.; Vollmar, A.; Trauner, D.; Thorn-Seshold, O. Photoswitchable Inhibitors of Microtubule Dynamics Optically Control Mitosis and Cell Death. Cell 2015, 162, 403-411.

(S2) Merino, F.; Pospich, S.; Funk, J.; Wagner, T.; Küllmer, F.; Arndt, H.-D.; Bieling, P.; Raunser, S. Structural transitions of F-actin upon ATP hydrolysis at near-atomic resolution revealed by cryo-EM. Nat. Struct. Mol. Biol. 2018, 25, 528-537.

(S3) Armarego, W. L. F.; Chai, C. L. L. Purification of Laboratory Chemicals, 2009, $5^{\text {th }}$ Edition, Elsevier Inc.

(S4) Lau, Y. H.; Spring, D. R. Efficient Synthesis of Fmoc-Protected Azido Amino Acids. Synlett 2011, 13, 1917-1919.

(S5) Tannert, R.; Milroy, L.-G.; Ellinger, B.; Hu, T.-S.; Arndt, H.-D.; Waldmann, H. Synthesis and Structure-Activity Correlation of Natural-Product Inspired Cyclodepsipeptides Stabilizing F-Actin. J. Am. Chem. Soc. 2010, 132, 3063-3077.

(S6) Milroy, L.-G.; Rizzo, S.; Calderon, A.; Ellinger, B.; Erdmann, S.; Mondry, J.; Verveer, P.; Bastiaens, P.; Waldmann, H.; Dehmelt, L.; Arndt, H.-D. Selective Chemical Imaging of Static Actin in Live Cells. J. Am. Chem. Soc. 2012, 134, 8480-8486.

(S7) Antonov, L.; Gergov, G.; Petrov, V.; Kubista, M.; Nygren, J. UV-Vis spectroscopic and chemometric study on the aggregation of ionic dyes in water. Talanta, 1999, 49, 99-106.

(S8) a) Chambers, R.W.; Kajiwara, T.; Kearns, D.R. Effect of dimer formation on the electronic absorption and emission spectra of ionic dyes. Rhodamines and other common dyes. J. Phys. Chem. 1974, 78, 380-387. b) Titov, E.; Granucci, G.; Götze, J. P.; Persico, M.; Saalfrank, P. Dynamics of azobenzene dimer photoisomerization: electronic and steric effects. J. Phys. Chem. Lett. 2016, 7, 3591-3596.

(S9) Cushman, M.; Nagarathnam, D.; Gopal, D.; Chakraborti, A. K.; Lin, C. M.; Hamel, E. Synthesis and Evaluation of Stilbene and Dihydrostilbene Derivatives as Potential Anticancer Agents That Inhibit Tubulin Polymerization. J. Med. Chem. 1991, 34, 2579-2588.

(S10) Frank, J. A.; Moroni, M.; Moshourab, R.; Sumser, M.; Lewin, G. R.; Trauner, D. Photoswitchable Fatty Acids Enable Optical Control of TRPV1. Nature Commun. 2015, 6, 7188 .

(S11) Friedman, O. M.; Gofstein, R. M.; Seligman, A. M. An Improved Method for the Synthetic Preparation of Methylcholanthrene. J. Am. Chem. Soc. 1949, 71, 3010-3013.

(S12) Thorn-Seshold, O.; Borowiak, M.; Trauner, D.; Hasserodt, J. Azoaryls as reversibly modulatable tubulin inhibitors (WO2015166295), 2014. 